\author{
UNIVERSIDADE DE SÃO PAULO \\ INSTITUTO DE ENERGIA E AMBIENTE \\ PROGRAMA DE PÓS GRADUAÇÃO EM ENERGIA
}

THAIS ARAUJO RATO TARELHO

A EFETIVIDADE DA ANÁLISE DE IMPACTO REGULATÓRIO NA AGÊNCIA NACIONAL DE ENERGIA ELÉTRICA: O CASO DAS DEMAIS INSTALAÇÕES DE TRANSMISSÃO

SÃO PAULO

2021 
THAIS ARAUJO RATO TARELHO

\section{A EFETIVIDADE DA ANÁLISE DE IMPACTO REGULATÓRIO NA AGÊNCIA NACIONAL DE ENERGIA ELÉTRICA: O CASO DAS DEMAIS INSTALAÇÕES DE TRANSMISSÃO}

Dissertação apresentada ao Programa de PósGraduação em Energia do Instituto de Energia e Ambiente da Universidade de São Paulo para obtenção do título de Mestre em Ciências.

Orientador: Prof. Dr. Célio Bermann

Versão corrigida

SÃO PAULO

2021 
AUTORIZO A REPRODUÇÃO E DIVULGAÇÃO TOTAL OU PARCIAL DESTE TRABALHO POR QUALQUER MEIO CONVENCIONAL OU ELETRÔNICO PARA FINS DE ESTUDO E PESQUISA, DESDE QUE CITADA A FONTE

FICHA CATALOGRÁFICA

Tarelho, Thais Araújo Rato.

A efetividade da análise de impacto regulatório na Agência Nacional de Energia Elétrica: o caso das demais instalações de transmissão. /Thais Araújo Rato Tarelho; orientador: Célio Bermann. - São Paulo, 2021.

$149 \mathrm{f} .:$ il; $30 \mathrm{~cm}$.

Dissertação (Mestrado em Ciências) - Programa de PósGraduação em Energia - Instituto de Energia e Ambiente da Universidade de São Paulo.

1. Energia elétrica. 2. Transmissão de energia elétrica. 3. Agências reguladoras. 4. Instalações elétricas. I. Título. 
Nome: TARELHO, Thais Araujo Rato

Título: A efetividade da Análise de Impacto Regulatório na Agência Nacional de Energia Elétrica: o caso das Demais Instalações de Transmissão

Dissertação apresentada ao Programa de PósGraduação em Energia do Instituto de Energia e Ambiente da Universidade de São Paulo para obtenção do título de Mestre em Ciências.

Orientador: Prof. Dr. Célio Bermann

Aprovado em:

Banca Examinadora

Prof. Dr. Instituição

Julgamento

Assinatura

Prof. Dr. Instituição

Julgamento Assinatura

Prof. Dr. Instituição

Julgamento Assinatura

Prof. Dr. Instituição

Julgamento Assinatura 
DEDICATÓRIA

Para os sempre amados Argemiro Domingos de Araujo e Uilem Ferreira Rato 


\section{AGRADECIMENTOS}

A Universidade pública e gratuita.

Aos meus colegas de mestrado, Raiana, Paola e Mariana pelos cafés compartilhados, pelos ensinamentos indispensáveis em engenharia, geologia, sociologia e química e pelo apoio de sempre.

Ao Diego, por me dar a força necessária para finalizar o trabalho, me apoiar e acreditar em mim. Parabéns para nós, Diego!

Aos meus colegas de trabalho da "vanguarda regulatória", em especial a Aline e Yasmin, pela companhia diária.

Aos meus amigos de sempre, pelos valiosos e necessários momentos de distração.

Aos meus colegas do NBFA, pelas experiências compartilhadas.

Ao meu orientador, Prof. Dr. Célio Bermann pela generosidade, paciência e precisão nas orientações.

A Adriana da secretaria de pós graduação, por sempre estar disposta a auxiliar.

À minha família, por vibrar comigo a cada pequena e grande conquista.

Aos meus pais, por todo o amor e por, mesmo nos momentos mais adversos, me incentivarem a continuar no caminho da ciência e dos estudos.

Ao meu irmão e cunhada por me ouvirem, sempre.

A minha sogra, por partilhar comigo a felicidade de ter ingressado no mestrado. 
Ao Renato, meu melhor companheiro dessa e das melhores jornadas da minha vida, por todo amor, apoio, carinho e compreensão. Obrigada! 
"A persistência é o menor caminho do êxito" (Charles Chaplin) 


\section{RESUMO}

TARELHO, Thais Araujo Rato. A efetividade da Análise de Impacto Regulatório na Agência Nacional de Energia Elétrica: o caso das Demais Instalações de Transmissão. 2020. Dissertação (Mestrado em Ciências) - Programa de Pós-Graduação em Energia da Universidade de São Paulo, São Paulo, 2021.

A Análise de Impacto Regulatório é uma ferramenta de tomada de decisão que permite a avaliação de medidas regulatórias a serem implementadas diante de um problema regulatório verificado.

Surgida nos Estados Unidos e amplamente adotada pelos países integrantes da OECD, teve sua aplicação iniciada no Brasil em meados de 2013, com a adoção de medidas impostas pelo Programa Fortalecimento da Capacidade Institucional para Gestão em Regulação.

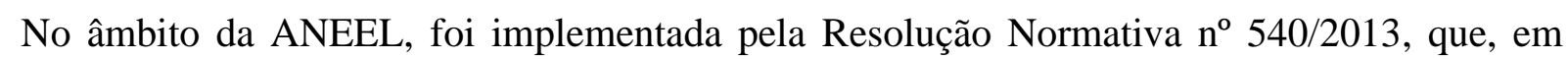
conjunto com os processos de participação pública na Agência, resultam em ferramentas de governança e tomada de decisão.

Diante do contexto de implantação da Análise de Impacto Regulatório na ANEEL, foi avaliado o processo de publicação de Resolução Normativa ${ }^{\circ}$ 758/2017 que determinou a transferência das Demais Instalações de Transmissão operadas pelas transmissoras para as Distribuidoras. A presente investigação tem por objetivo principal avaliar o processo de Análise de Impacto Regulatório no caso concreto no âmbito da ANEEL.

Palavras-Chave: Agência Nacional de Energia Elétrica, ANEEL, qualidade da regulação, participação pública, Análise de Impacto Regulatório, Demais Instalações de Transmissão. 


\begin{abstract}
RATO TARELHO, Thais Araujo. The effectiveness of the Regulatory Impact Analysis in the National Electric Energy Agency: the case of Other Transmission Facilities. 2021. Master Thesis (Master of Science) - Graduate Program in Energy at the University of São Paulo, São Paulo, 2021.

Regulatory Impact Analysis is a decision-making tool that allows the assessment of regulatory measures to be implemented in the face of a verified regulatory problem.

Appeared in the United States and widely adopted by OECD member countries, its application began in Brazil in mid-2013, with the adoption of measures imposed by the Institutional Capacity Building Program for Regulation Management.

Within ANEEL, it was implemented by Normative Resolution No. 540/2013, which, together with the public participation processes at the Agency, results in governance and decisionmaking tools.

In view of the context of implementation of the Regulatory Impact Analysis at ANEEL, the publication process of Normative Resolution No. 758/2017 was evaluated, which determined the transfer of the Other Transmission Facilities operated by the transmission companies to the Distributors. The main objective of this investigation is to evaluate the Regulatory Impact Analysis process in the specific case within ANEEL.
\end{abstract}

Keywords: National Electric Energy Agency, ANEEL, Regulation Quality, Public Participation, Regulatory Impact Analysis, Other Transmission Facilities. 


\section{LISTA DE FIGURAS}

Figura 1 - Questões que devem ser respondidas por uma AIR.....................................34

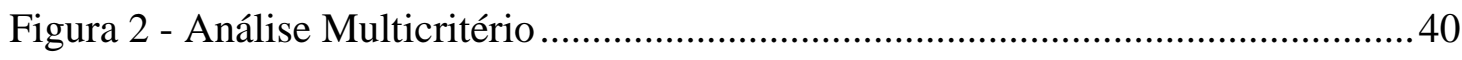

Figura 3 - Aplicação da Análise de Impacto Regulatório na União Europeia...............47

Figura 4 - Aproveitamento das contribuições da segunda fase da Audiência Pública ${ }^{\circ}$ $41 / 2015$

Figura 5 - Porcentagem de gerentes e diretores participantes da pesquisa 104

Figura 6 - quantidade de distribuidoras e transmissoras participantes da pesquisa.... 105

Figura 7 - Existência de DIT na base de ativos das empresas participantes da pesquisa

Figura 8 - Participantes afetados pela determinação de transferência das DIT 106

Figura 9 - Oportunização da ampla manifestação dos agentes na visão dos participantes da pesquisa. 106

Figura 10 - Oportunidade de manifestação divergente na percepção dos participantes da pesquisa

Figura 11 - Conhecimento sobre o resultado final da Audiência Pública nº 41/2015 pelos participantes da pesquisa 108

Figura 12 - Opinião sobre a melhor alternativa técnica e regulatória na visão dos participantes da pesquisa 108

Figura 13 - Conhecimento dos participantes da pesquisa sobre a AIR 109

Figura 14 - Proposição da transferência das DIT e suficiência da AIR na opinião dos participantes da pesquisa 


\section{LISTA DE TABELAS}

Tabela 1 - O processo de tomada de decisão da medida regulatória 31

Tabela 2 - Resumo da implementação da AIR nas Agências Reguladoras Brasileiras.

Tabela 3 - Modelo de AIR. 51

Tabela 4 - AIR de acordo com o Decreto 10.411/2020 _............................................54

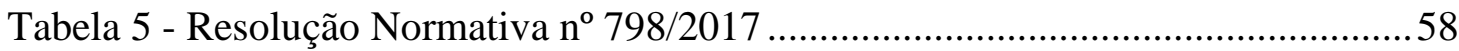

Tabela 6 - Evolução do conceito de Rede Básica ..........................................................69

Tabela 7 - Minuta de Resolução Normativa - $1^{\text {a }}$ fase da Audiência Pública no 41/2015 75

Tabela 8 - Resumo das contribuições à primeira fase da Audiência Pública no 41/2015

Tabela 9 - Síntese da minuta de resolução. .87

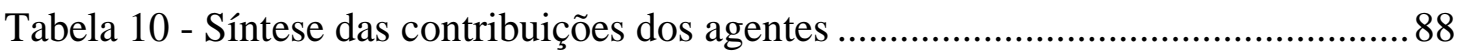

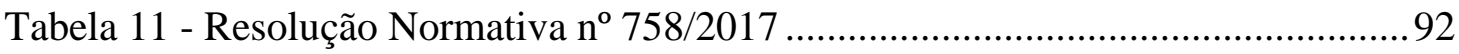

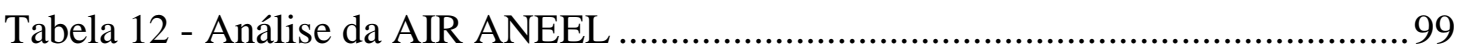

Tabela 13 - Análise das Audiências/Consultas Públicas realizadas em 2019 .............118 


\section{LISTA DE ANEXOS}

Anexo I: Análise de Impacto Regulatório do processo de transferência das DIT......141

Anexo II: Integra da pesquisa empírica. 


\section{LISTA DE ABREVIATURAS E SIGLAS}

ABRACE: Associação Brasileira de Grandes Consumidores de Industriais de Energia e de Consumidores Livres.

ABRADEE: Associação Brasileira de Distribuidores de Energia Elétrica.

ABRATE: Associação Brasileira das Empresas de Transmissão de Energia Elétrica.

AGU: Advocacia Geral da União.

AIR. Análise de Impacto Regulatório ou Avaliação de Impacto Regulatório.

AMFORP: American Foreign Power Company.

ANA: Agência Nacional de Águas

ANAC: Agência Nacional de Aviação Civil.

ANATEL: Agência Nacional de Telecomunicações.

ANCINE: Agência Nacional de Cinema.

ANEEL: Agência Nacional de Energia Elétrica.

ANP: Agência Nacional de Petróleo, Gás Natural e Biocombustíveis.

ANS: Agência Nacional de Saúde.

ANTAQ: Agência Nacional de Transportes Aquaviários.

ANTT: Agência Nacional de Transportes Terrestres.

ANVISA: Agência Nacional de Vigilância Sanitária.

AP: Audiência Pública.

ARR: Análise de Resultado Regulatório.

Art: Artigo.

Casa Civil: Ministério da Casa Civil

CEEE: Companhia Estadual de Energia Elétrica.

CELG GT: Companhia Energética de Goiás Geração e Transmissão.

CEMIG: Companhia Energética de Minas Gerais.

CEMIG GT: Companhia Energética de Minas Gerais Geração e Transmissão.

CHESF GT. Companhia Hidrelétrica do Rio São Francisco Geração e Transmissão.

COPEL GT: Companhia Paranaense de Energia Geração e Transmissão.

CP: Consulta Pública.

CPFL Distribuição: Companhia Paulista de Força e Luz.

CTEEP: Companhia de Transmissão de Energia Elétrica Paulista.

DEMEI: Departamento Municipal de Energia do Ijuí 
DIT: Demais Instalações de Transmissão.

DNAEE: Departamento Nacional de Águas e Energia Elétrica.

EDP: EDP - Distribuição Energia

ELEKTRO: Elektro Distribuidora de Energia S.A.

ELETROBRAS: Centrais Elétricas Brasileiras S. A.

ELETRONORTE: Centrais Elétricas do Norte do Brasil S.A.

ELETROSUL: Companhia de Geração e Transmissão de Energia Elétrica do Sul do Brasil.

FNE: Federação Nacional dos Engenheiros.

FURNAS: Furnas Centrais Elétricas S.A.

$\mathrm{kV}$ : Quilovolt

Light: Brazilian Traction, Light and Power.

MME: Ministério de Minas e Energia.

N/A: Não se aplica

OECD. Organisation for Economic Co-operation and Development.

ONS: Operador Nacional do Sistema Elétrico.

PF: Procuradoria Federal da ANEEL.

PRO_REG: Programa de Fortalecimento da Capacidade Institucional para Gestão em Regulação.

PRORET: Procedimento de Regulação Tarifária.

RAP: Receita Anual Permitida.

REN: Resolução Normativa publicada pela ANEEL.

RESEB: Projeto de Restruturação do Setor Elétrico.

SCT: Superintendência de Concessões, Permissões e Autorizações de Transmissão e Distribuição da ANEEL.

SFF: Superintendência de Fiscalização Econômica e Financeira da ANEEL.

SGT: Superintendência de Gestão Tarifária da ANEEL.

SRD: Superintendência de Regulação dos Serviços de Distribuição da ANEEL.

SRM: Superintendência de Regulação Econômica e Estudos de Mercado da ANEEL.

SRT: Superintendência de Regulação dos Serviços de Transmissão da ANEEL. 


\section{SUMÁRIO}

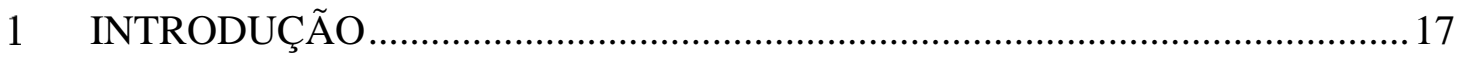

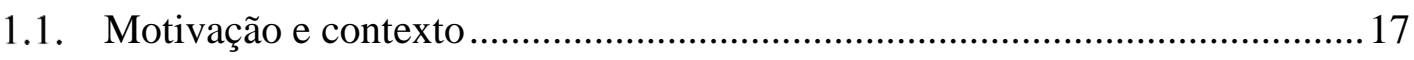

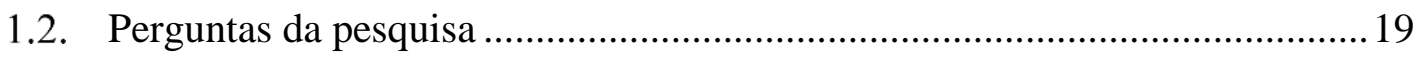

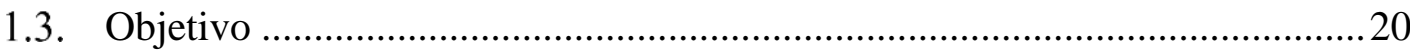

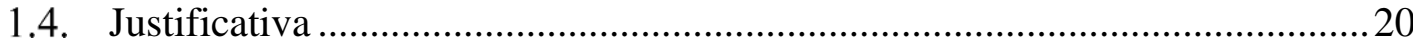

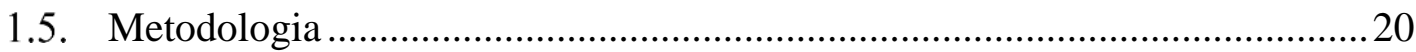

2 RECORTE HISTÓRICO E BASE BIBLIOGRÁFICA .......................................2 24

2.1. A Análise de Impacto Regulatório ou Avaliação de Impacto Regulatório -

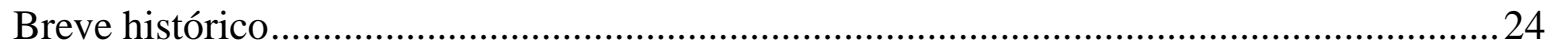

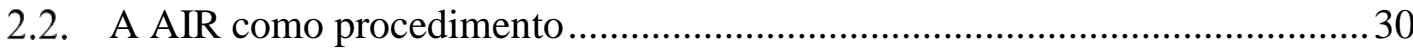

2.2.1. Os métodos de avaliação para elaboração da AIR................................... 35

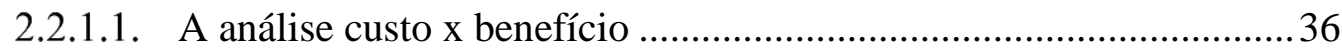

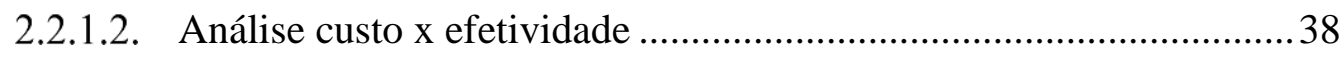

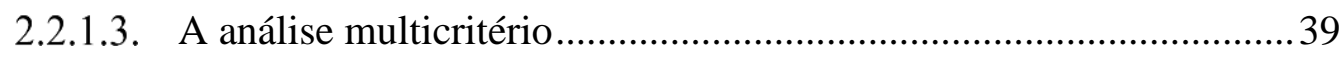

2.2.2. A consulta pública na AIR ............................................................... 40

2.2.3. Possíveis classificações da AIR .......................................................... 42

2.3. A experiência internacional: implementação da AIR nos Estados Unidos e na União Europeia 43

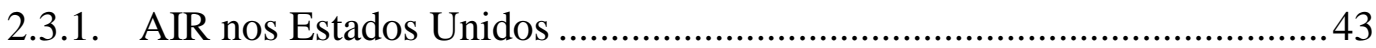

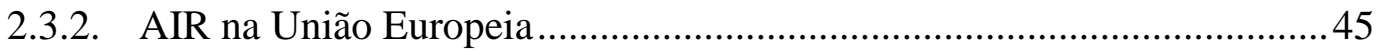

2.4. O Caso Brasileiro: a implementação da AIR no Brasil .................................47

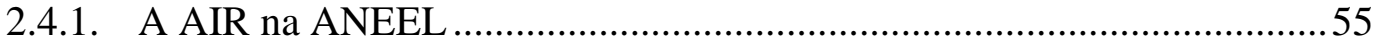

2.4.1.1. Outros mecanismos de qualidade regulatória - envolvimento da sociedade e necessária participação pública: A Consulta Pública na ANEEL ..............59

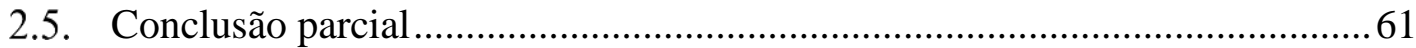

3 ESTUDO DE CASO: DEMAIS INSTALAÇÕES DE TRANSMISSÃO - DIT 63 
3.1. Desenho institucional do setor de transmissão de energia elétrica brasileiro. 63

3.1.1. O setor de transmissão e as DIT 70

3.2. O conflito entre Transmissoras e Distribuidoras: a transferência das DIT .....72

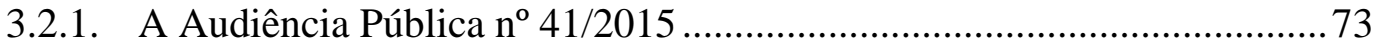

3.2.1.1. Primeira fase da Audiência Pública nº 41/2015 _............................. 73

3.2.1.2. A segunda fase da Audiência Pública no 41/2015 ............................ 84

3.2.2. Desdobramentos e consequências da Audiência Pública no 41/2015 ......92 92

3.2.2.1. Desdobramentos e consequências da Audiência Pública nº 41/2015: o problema ainda persiste 95

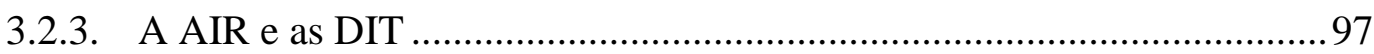

3.2.3.1. A AIR poderia ter previsto os desdobramentos do caso? ................ 101

3.2.3.1.1. Pesquisa empírica.................................................................... 103

3.2.3.2. A efetividade, adequação e eficácia dos processos de AIR e participação pública no caso das DIT

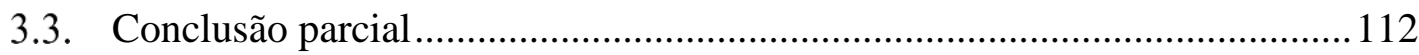

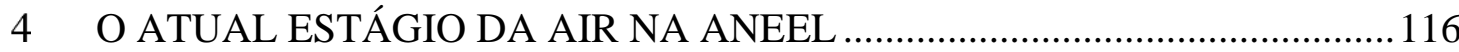

4.1. O cumprimento da Resolução Normativa $\mathrm{n}^{\mathrm{o}}$ 798/2017 ................................ 116

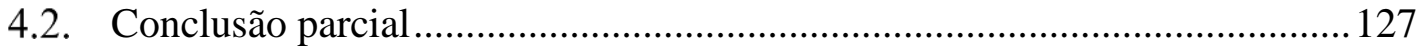

5 CONCLUSÃO

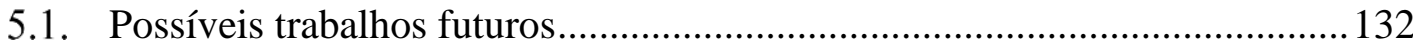

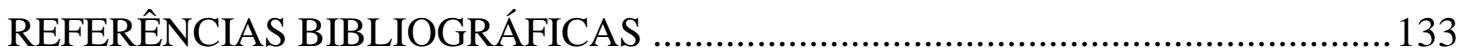




\section{INTRODUÇÃO}

Essa seção corresponde a introdução relacionada a Análise de Impacto regulatório no âmbito da ANEEL e o caso da determinação de transferência das DIT.

\subsection{MOTIVAÇÃO E CONTEXTO}

Desde a criação da Agência Nacional de Energia Elétrica - ANEEL em 1997 pela Lei 9.427 com a função primordial de regular e fiscalizar a produção, transmissão, distribuição e comercialização de energia elétrica, em conformidade com as políticas e diretrizes do Governo Federal, a Agência vem implementando normas cujo objetivo principal é o de promover e permitir a concretização de políticas públicas.

Para a implantação desse arcabouço normativo, é dever da Agência implantar tais normas desde que essas sejam precedidas de processos estruturados de participação pública. Tal dever tem total aderência ao modelo regulatório democrático, que, em princípio, constrói a opção regulatória levando em consideração opiniões diversas dos agentes afetados.

Em que pese haver a necessidade legal de implementação de normas com a devida participação pública, não havia na Agência qualquer instrumento que possibilitasse uma análise detalhada das opções regulatórias relacionadas ao assunto tratado.

Nesse contexto, em 2013, por meio da Resolução Normativa n 540, a ANEEL instituiu a AIR de modo a permitir a instrumentalização da opção pela melhor escolha regulatória.

A AIR no âmbito da ANEEL é uma ferramenta de gestão da regulação que permite a partir da identificação de um problema regulatório, a comparação e a avaliação da melhor alternativa regulatória a ser implementada para o problema em questão. A presente investigação tem como objetivo principal, portanto, a avaliação dessa ferramenta no âmbito da Agência.

De acordo com a norma, a AIR deveria avaliar a relação custo x benefício de uma política e seria, em tese, obrigatória para toda implementação de ato normativo. A AIR, além de determinar o mencionado custo $\mathrm{x}$ benefício da norma, deveria também avaliar quais as opções regulatórias existem e são relacionadas ao tema em estudo. 
Passados aproximadamente 4 (quatro) anos da implementação da norma em questão e em razão da necessidade de reavaliação dessa por expressa previsão, a ANEEL propôs revisão do normativo com base em algumas premissas. Para tanto, foi realizado estudo detalhado com o principal objetivo de verificar o alcance da Resolução Normativa n ${ }^{\circ}$ 540/2013.

Em referido estudo foram analisados os atos normativos emitidos entre 2013 e 2016. A análise identificou que 51 (cinquenta e um) atos normativos implementados não apresentaram a AIR, sem qualquer justificativa para tanto, outras tantas resoluções apresentaram a IR dentro de Notas Técnicas ou mesmo com análise incompleta. Além de elevado número que normas cuja publicação não foi precedida da mencionada análise, a Agência também não observou rigor nas AIR elaboradas.

Nesse contexto, o que se percebia era que, em que pese haver a determinação de aplicação da norma, por vezes essa não era efetiva o suficiente para que seu caráter cogente fosse observado.

Identificado o problema, dentre os atos normativos implementados durante o período avaliado, encontra-se a norma relacionada a transferência de ativos de energia elétrica entre concessionárias de transmissão e de distribuição de energia elétrica - as DIT, a qual suscitou um conflito de interesses entre transmissoras e distribuidoras, visto que estava em discussão, além da transferência desses ativos, o impacto . Tal determinação foi objeto de norma que se encontra dentre as resoluções a AIR foi realizada dentro da Nota Técnica que analisou o caso.

De fato, a falta de análise aprofundada das possíveis consequências de implementação de norma que determinasse de modo compulsório a transferência dessas instalações entre concessionárias de transmissão e distribuição de energia elétrica, trouxe relevante impacto ao processo normativo, envolvendo a propositura de ações judiciais pelos agentes afetados, recursos administrativos e dois anos de embates até solução (quase) definitiva.

A experiência sobre o tema demonstra que, inclusive, ainda não há solução definitiva sobre o assunto, havendo espaço para novos conflitos se a questão for novamente discutida no âmbito da ANEEL. 
Isso ocorre porque, a transferência dessas instalações envolve perda de receita por parte das concessionárias que terão suas instalações transferidas para outras empresas. Por óbvio, a perda de valor de receita e possibilidade de investimento futuro pelas transmissoras e o consequente acréscimo de receita e aumento da possibilidade de investimento nessas instalações para as concessionárias de distribuição que receberão esses ativos em transferência, implica em evidente conflito de interesses que em tese poderia ter sido previsto pela Agência, caso a AIR tivesse sido realizada a contento.

A existência da problemática mencionada reforça a análise já efetuada pela própria Agência sobre a inexistência da análise prévia e contundente dos atos a serem implementados.

Após a identificação dos mencionados fatores, a ANEEL passou a tratar com mais rigor a necessidade de elaboração e efetivação da uma análise regulatória prévia, no entanto, ainda não existem dados que relacionem a alteração da mudança com o cumprimento da norma e com a efetividade da análise realizada.

Diante desse contexto, a presente investigação teve como objetivo principal avaliar se a AIR poderia ter evitado os conflitos relacionados ao caso da transferência das DIT para verificar se o instrumento seria o suficiente para impedir todos os entraves causados no setor em decorrência da implementação da regulação. Posteriormente, a investigação pretendeu verificar se as alterações promovidas pela ANEEL sobre a AIR foram incorporadas no processo de tomada de decisão da Agência.

\subsection{PERGUNTAS DA PESQUISA}

A presente investigação pretendeu responder algumas questões que nortearam a pesquisa:

(i) O modelo de AIR implementada pela Resolução Normativa $n^{\circ}$ 540/2013 aplicado ao caso de transferência das DIT foi o suficiente para identificar os problemas advindos da regulação sobre o tema?

(ii) O modelo implementado pela Resolução Normativa $n^{\circ} 798 / 2017$ é o ideal para a Agência?

(iii)O modelo implementado pela Resolução Normativa $n^{\circ} 798 / 2017$ cumpriu o papel ao qual se propôs? 
(iv)A participação pública prevista é eficiente?

\subsection{OBJETIVO}

Diante do contexto e da hipótese aventada, o principal objetivo da presente dissertação foi o de avaliar se a análise realizada no âmbito das DIT foi suficiente para a tomada de decisão do caso. Posteriormente, se verificou se as alterações promovidas pela ANEEL na norma que dispõe sobre a AIR foram suficientes para equalizar os problemas anteriormente presentes e apontados pela Agência.

Como objetivo secundário, se pretendeu realizar uma revisão bibliográfica no âmbito nacional e no âmbito internacional.

\subsection{JUSTIFICATIVA}

Pretendeu-se avaliar a efetividade da realização da AIR no processo decisório da Agência, a efetividade do processo de participação popular para contribuição da AIR, bem como apontar possíveis pontos de melhoria no processo existente.

Isso porque, muito embora a AIR se proponha a auxiliar na escolha da melhor opção regulatória, tal objetivo principal não havia sido alcançado quando da avaliação inicial realizada pela própria ANEEL. Desse modo, para confirmar ou refutar tal afirmativa colocada pelo próprio órgão regulador, duas foram as análises realizadas: (i) a primeira se concentrou em avaliar se a aplicação da AIR em um caso concreto, o caso de transferência das DIT, poderia ter evitado problemas relacionados ao caso; (ii) a segunda se concentrou em analisar se as Resoluções Normativas publicadas pós revisão da Resolução Normativa $n^{\circ}$ 798/2017, especialmente as do ano de 2019, de fato obedeceram ao quanto determinado para a elaboração da AIR.

\subsection{METODOLOGIA}

A investigação objeto da presente dissertação dependeu de entendimento relacionado aos objetivos a serem atingidos com a aplicação da teoria da AIR. Referidos aspectos foram 
avaliados a luz de um recorte histórico sobre a AIR nos âmbitos nacional e internacional, sendo que tal entendimento foi obtido por meio da pesquisa histórica relacionada ao tema.

O material analisado foi obtido em sua maioria em pesquisas a dissertações sobre o tema. A plataforma Mendely também foi utilizada como fonte de busca da bibliografia.

Após o entendimento sobre a teoria, foi analisada a AIR aplicada ao caso das DIT. Para tanto, foi avaliado se existia outra opção regulatória para o caso, quais eram as opções, se haveria a possibilidade de mencionar os custos que a transferência implicaria e se os problemas advindos da implantação da regulação poderiam ter sido previstas.

Para o perfeito entendimento do trabalho foi realizado um corte metodológico, de modo que, quando mencionados, os termos a seguir significam ${ }^{1}$ :

(i) ADEQUADO. [Filosofia geral]. O que tem as qualidades intrínsecas a ideia verdadeira.

(ii) EFETIVO. [Teoria geral do direito]. O que existe na verdade, em oposição ao que é possível; real; permanente

(iii) EFICÁCIA. [Teoria geral do direito e filosofia do direito]. É a qualidade da norma vigente de produzir, no seio da coletividade, efeitos jurídicos concretos, considerando, portanto, não só a questão da sua condição técnica de aplicação, observância ou não pelas pessoas a quem se dirige, mas também a da sua adequação em face da realidade social, por ela disciplinada e dos valores vigentes na sociedade, o que conduziria ao seu sucesso. A eficácia diz respeito, portanto, ao fato de se saber se os destinatários da norma ajustam ou não seu comportamento em maior ou menor grau, às prescrições normativas, ou seja, se cumprem o não os comandos jurídicos e se os aplicam ou não.

(iv) IDEAL. [Filosofia geral]. Que consiste em uma ideia; aquilo que apresenta certo caráter de elevação estética, moral ou intelectual; perfeito; aquilo que é construído ou imaginado pelo espirito, em oposição ao que existe verdadeiramente; o que tem a existência apenas na ideia; o que satisfaz a

\footnotetext{
${ }^{1}$ DINIZ. Maria Helena. Dicionário Jurídico. $3^{\text {a }}$ edição. São Paulo. Saraiva.2012.
} 
inteligência e o sentimento humanos; modelo idealizado por um artista; sublimidade; projeção de uma ideia; padrão.

(v) RELEVANTE. Aquilo que tem importância; evidente; apreciável; indispensável; o que tem grande valor; admissível; o que tem fundamento; matéria que pode influenciar em uma decisão.

Para a análise dos efeitos da decisão de transferência das DIT, foram aplicados questionários por meio da ferramenta Google Forms para agentes afetados. Foram enviados questionários para colaboradores das empresas: CHESF, FURNAS, CEEE, ELETROSUL, ELETRONORTE, COPEL, CELG, CEMIG, CTEEP, ELEKTRO, CPFL Distribuição e EDP.

Os questionários tomaram o cuidado de questionar sobre a autorização de divulgação do nome de quem responde a pesquisa.

Para os agentes setoriais, foram realizadas perguntas específicas sobre o caso das DIT e sobre os processos de realização de AIR e participação pública, quais sejam:

(i) Qual o seu cargo na empresa em que trabalha;

(ii) A empresa em que você trabalha se enquadra como transmissora ou distribuidora de energia elétrica?;

(iii) Você sabe o que são Demais Instalações de Transmissão - DIT?;

(iv) A empresa em que você trabalha contém em sua base de ativos Demais Instalações de Transmissão - DIT?;

(v) Você se lembra da Audiência Pública $n^{\circ}$ 41/2015 promovida pela Agência Nacional de Energia Elétrica ("ANEEL") que tratou da transferência das Demais Instalações de Transmissão - DIT?;

(vi) Na sua opinião, a Audiência Pública $n^{\circ}$ 41/2015 oportunizou a ampla manifestação dos agentes?;

(vii) Na sua opinião, na condução da Audiência Pública no 41/2015, a ANEEL se mostrou aberta a acatar opiniões e soluções diversas daquelas já postas no âmbito da Audiência Pública?;

(viii) Você conhece o resultado final da Audiência Pública n 41/2015?; 
(ix) Você considera que a decisão de transferência das Demais Instalações de Transmissão - DIT considerou a melhor alternativa técnica, regulatória e financeira?;

(x) A empresa em que você trabalha foi afetada pela proposta de Transferência das Demais Instalações de Transmissão - DIT incluída na Audiência Pública $n^{\circ}$ 41/2015 promovida ANEEL?;

(xi) Você conhece a Análise de Impacto Regulatório?;

(xii) Na sua opinião, caso tivesse sido feita a Análise de Impacto Regulatório para o caso das Demais Instalações de Transmissão - DIT, a sua transferência teria sido proposta?;

(xiii) Na sua opinião, caso tivesse sido realizada a Análise de Impacto Regulatório, os questionamentos e ações judiciais que permearam a Audiência Pública ${ }^{\circ}$ 41/2015 poderiam ter sido evitados?;

(xiv) Você tem algum comentário adicional sobre a relação entre a Análise de Impacto Regulatório e a decisão de transferência das Demais Instalações de Transmissão?

As opiniões colhidas por meio da pesquisa foram utilizadas nas duas fases da investigação: (i) a primeira parte relacionada as DIT; (ii) a segunda parte relacionada a análise quantitativa das Resoluções emitidas no ano de 2019.Nessa fase foi avaliado se a AIR de fato foi aplicada às Resoluções publicadas pela ANEEL. 


\section{RECORTE HISTÓRICO E BASE BIBLIOGRÁFICA}

A seguir se apresenta a revisão bibliográfica relacionada a Análise de Impacto Regulatório nos âmbitos nacional e internacional.

\subsection{A ANÁliSE DE IMPACTO REGULATÓRIO OU AVALIAÇÃO DE IMPACTO REGULATÓRIO - BREVE HISTÓRICO}

De acordo com a teoria pura da economia em que mercados econômicos funcionam em perfeito equilíbrio e simetria, a intervenção do Estado nessa relação, além de não se justificar, também não consistiria em benefícios adicionais ao seu funcionamento, ocasionando, em verdade, um desequilíbrio em seu funcionamento. (Oliveira, 2015).

No entanto, em setores que não são regidos diretamente pelas leis da oferta e procura ou mesmo nos quais há assimetria nas informações de mercado que impedem o perfeito funcionamento das teorias básicas de economia, a intervenção governamental se faz necessária e é observada em maior ou menor grau. Tais falhas de mercado, que impedem necessariamente a auto regulação, podem, ainda das palavras de Oliveira (2015), ser decorrentes das seguintes fontes:

(i) Monopólio e poder de mercado: assim entendido como o cenário em que uma única empresa presta determinados serviços, o que impede, portanto, a competição de preços.

(ii) Externalidades: cenário em que custos e benefícios são integralmente absorvidos pelos atores da atividade econômica;

(iii)Bens coletivos: entendidos como aqueles não rivais e não exclusivos, de modo que o uso por um indivíduo não afeta o uso por outro. Tais bens são em geral, providos pelo Estado, visto que não há interesse da iniciativa privada em provê-los para a população

(iv)Assimetria de informações: caracterizada pela precariedade ou diferença do nível de informações aos quais as partes são submetidas ou mesmo o consumidor final do produto.

É nesse contexto de desigualdades e assimetrias que intervenções estatais na econômica tem seu papel. O modelo de regulação, é um desses tipos de intervenção, que tem como 
objetivo, de forma macro e por meio de tecnicidade, promover a correção dessas falhas de mercado, garantindo a alocação eficiente de recursos e repressão do abuso econômico.

Por regulação, de acordo com a Casa Civil (2018, p.7) entende-se uma forma de atuação do Estado para estabelecer "obrigações que devem ser cumpridas pelo setor privado, pelos cidadãos e pelo próprio governo. (...) um dos principais instrumentos por meio dos quais os governos promovem o bem-estar social e econômico dos seus cidadãos”.

Ainda a Casa Civil ${ }^{2}$ (2018, p.22 apud Carlos Ari Sundfeld, Direito Administrativo Econômico. 2002, p. 18):

\begin{abstract}
A regulação, enquanto espécie de intervenção estatal, manifesta-se tanto por poderes e ações com objetivos declaradamente econômicos (o controle de concentrações empresariais, a repressão de infrações à ordem econômica, o controle de preços e tarifas, a admissão de novos agentes no mercado) como por outros com justificativas diversas, mas efeitos econômicos inevitáveis (medidas ambientais, urbanísticas, de normalização, de disciplina das profissões, etc.). Fazem regulação autoridades cuja missão seja cuidar de um específico campo de atividades considerado em seu conjunto (o mercado de ações, as telecomunicações, a energia, os seguros de saúde, o petróleo), mas também aquelas com poderes sobre a generalidade dos agentes da economia (exemplo: órgãos ambientais).
\end{abstract}

De acordo com Oliveira (2015), além de corrigir as falhas de mercado, a regulação, especialmente no contexto brasileiro, tem como papel também garantir direitos essenciais, com a diminuição da desigualdade social.

Complementarmente aos conceitos já expostos, a OECD (2012), entende a regulação, em um aspecto mais abrangente, como um conjunto de ações, normas, leis e regras pelas quais o governo estabelece atuação de entes públicos e privados.

E é no contexto da necessidade de tomada de decisão no âmbito regulatório que surge a AIR.

${ }^{2}$ SUNDFELD, Carlos Ari. Direito Administrativo Econômico. São Paulo. Editora Malheiros, 2002. 
Conforme definição da OECD (1997), a AIR é instrumento regulatório que tem como objeto principal auxiliar o regulador na tomada de decisão sobre a implementação de política regulatória perseguida.

Tal instrumento permite a análise crítica dos efeitos positivos e negativos que a implementação de uma medida regulatória pode trazer ao setor regulado e, se aplicada com a devida e necessária participação pública, pode ser instrumento que resulte no aumento da eficiência a qualidade das políticas implementadas.

Essa metodologia consiste, de forma resumida, em modelo que permite ao regulador avaliar e estimar custos e benefícios que a implementação de determinada política pode trazer aos regulados. Para além da identificação da dinâmica custo x benefício da implementação de determinada regulação, a AIR permite verificar e analisar outras formas de implantação dessa regulação, comparando a relação custo x benefício da implementação de cada uma das medidas postas.

RIA can help you to ensure that regulations are as efficient and effective as possible. Effective regulation is regulation that achieves the policy objective that led to it being made. Efficient regulation achieves these objectives at the lowest total cost - to all members of society. Efficiency and effectiveness are important because there are limits to the amount and type of regulation able to be absorbed within economies and enforced effectively by governments. Regulation has costs as well as benefits, and inappropriate regulation can stifle economic growth by putting obstacles in the way of doing business and by creating perceptions of a negative environment. As well, making and enforcing regulation places large demands on government administrations. It is important therefore that it is well designed. (OECD, 2008, p.4)

Análise de impacto regulatório (AIR), como definida pela OECD (OECD, 2008, p. 14), é a ferramenta política sistemática utilizada para examinar e medir os benefícios, os custos e os efeitos prováveis de uma regulação nova ou já existente. Trata-se de uma forma analítica de informar os tomadores de decisão, e sua estrutura é, tipicamente, dividida da seguinte forma: título da proposta; objetivo e efeito esperado da política regulatória; avaliação do problema político; consideração das opções alternativas; avaliação de todos os impactos distributivos; resultados da consulta pública; estratégias de compliance; e processos para monitoramento e avaliação.(Salgado, Lucia Helena, Borges, Eduardo Bizzo de Pinho, 2010, p. 7)

Ainda de acordo com a Casa Civil (2018), a AIR é uma ferramenta que permite uma avaliação sistemática de um problema regulatório, os impactos das alternativas apontadas, tendo como finalidade principal orientar e subsidiar a tomada de decisões. 
Muito embora a discussão sobre a AIR seja relativamente recente no Brasil, a questão é discutida na OECD desde $1997^{3}$. Em verdade, muito antes da discussão sobre AIR ser pauta de estudos pela OECD, essa já fazia parte da regulação americana, tendo surgido nos Estados Unidos na década de 80, após sucessivos questionamentos judiciais sobre temas regulatórios, por meio do Executive Order (decreto, tradução nossa) n 12.291/1981.

Tal decreto, além de ter aumentado a responsabilidade das agências reguladoras, determinou que a administração obedecesse a alguns princípios quando da execução da atividade regulatória. Nesse contexto, a partir de sua publicação, se iniciou uma fase em que:

(i) As decisões administrativas deveriam ser baseadas em informações adequadas, relacionadas a necessidade e as consequências da decisão;

(ii) A intervenção regulatória só deve ser realizada casos os benefícios da medida superem os custos;

(iii)A decisão deve ser tomada sempre com objetivo de maximizar os benefícios para a sociedade;

(iv)Entre diversas opções regulatórias apresentadas, deve ser escolhida sempre a de menor custo para a sociedade;

(v) Devem ser estabelecidas prioridades regulatórias, levando-se em consideração o cenário econômico e regulações futuras.

Para que tais objetivos fossem alcançados, o decreto também estabeleceu como ferramenta fundamental a atualização da AIR, tendo mencionando-o expressamente em seu texto como forma de se chegar as determinações estabelecidas para a tomada de decisões regulatórias:

In order to implement Section 2 of this Order, each agency shall, in connection with every major rule, prepare, and to the extent permitted by law consider, a Regulatory Impact Analysis. Such Analyses may be combined with any Regulatory Flexibility Analyses performed under 5 U.S.C. 603 and 604.

A partir da aplicação do instrumento nos Estados Unidos, a implantação da AIR foi expandida, a União Europeia, por exemplo, adotou o conceito em 2001, com a aprovação do Livro Branco sobre a Governança Europeia. O Livro Branco para Governança Europeia 
estabeleceu princípios a serem seguidos para a atividade normativa europeia, dentre eles, a necessidade de garantir a participação popular e a eficácia das decisões.

Nesse contexto, na versão em português, o Livro Branco estabelece que decisões no âmbito da comunidade europeia devem ser realizadas com base em uma análise que permita verificar qual o nível e intervenção é necessário e mesmo se tal intervenção se demonstra necessária.

Uma regulamentação melhor e mais rápida - combinar os instrumentos políticos para obter melhores resultados.

A Comissão Europeia identificou sete fatores de melhoria da regulamentação: As propostas devem ser elaboradas com base numa análise que permita concluir se é ou não necessária uma intervenção de nível comunitário. (...).

Ainda no contexto internacional, em 2012 a OECD publicou recomendação do Conselho sobre Política Regulatória e Governança que indicou a instituição da AIR como instrumento de governança e transparência a ser inserido no processo decisório das agências reguladoras. De acordo com o documento, a AIR deve ser instrumento que permita identificar os objetivos da política que se pretende implementar e avaliar se a intervenção é adequada.

Essa análise deve possibilitar a identificação das várias formas de regulação e apontar pela melhor forma de resolver a questão posta em estudo, visando, primordialmente que a regulação seja implementada com qualidade e transparência aos regulados.

Há que se ressaltar nesse ponto que, além da elaboração de uma boa análise custobenefício, um dos pontos primordiais para assegurar a qualidade do processo de AIR consiste na ampla participação popular sobre o processo. Essa participação permite que o ponto de vista do regulado seja considerado em possíveis revisões da AIR realizada.

Já no contexto brasileiro, muito embora o conceito de AIR tenha se fixado nas agências reguladoras a partir de 2012, em 2002, com a publicação do PRO_REG por meio do Decreto 6.062/2007, alguns princípios do instrumento já estavam presentes, tais como a necessidade de fortalecer o sistema regulatório e a capacidade de formulação e análise das políticas públicas. 
O PRO_REG que consistiu em uma série de estudos e fomento para a capacitação relacionada a melhora da atividade regulatória (Casa Civil, 2013) já constava, por exemplo, a necessidade de que a elaboração de atos normativos deveria ser precedida de definição do objeto ao qual se pretende alcançar com a regulação pretendida, alternativas regulatórias, análise de custo benefício, além da participação popular, havendo a partir de

A partir de então, diversas Agência Reguladoras iniciaram o processo de implantação da AIR, sendo a primeira a ANS.

Já em 2018, a Casa Civil, após amplo processo de participação pública e debates com as agências reguladoras, publicou as Diretrizes Gerais e Guia Orientativo para elaboração de Análise de Impacto Regulatório - AIR, por meio do qual dá as diretrizes relacionadas a forma pela qual deve se dar a elaboração de uma análise de impacto regulatório.

Em 2019, pela primeira vez na história brasileira, a AIR foi normatizada no âmbito legal, tendo sido inserida como etapa obrigatória no processo de decisão das Agências Reguladoras por meio da Lei 13.848/2019, a qual dispôs sobre a gestão, a organização, o processo decisório e o controle social das agências reguladoras.

Ainda em 2019, a Lei n ${ }^{\circ} 13.874$, que dispôs sobre a instituição da declaração dos direitos de liberdade econômica, também determinou que a alteração ou proposição de atos normativos de interesse geral de agentes econômicos devem ser precedidos de AIR.

Desse modo, com a publicação das referidas leis, a implementação da AIR no Brasil deixou de ser simplesmente uma recomendação e passou a ser positivada no direito brasileiro.

Especificamente quanto à ANEEL, agência cuja atuação e adoção da AIR é objeto dessa investigação, logo após a publicação do relatório da OECD, em 2013, essa o implementou por meio da publicação da REN n 540/2013. O regulamento possui caráter cogente, sendo obrigatória sua realização precedente à implantação de novos atos regulatórios normativos.

Em que pese o caráter cogente da norma, o que se observou é que, por vezes, foram implementados atos de caráter normativo sem que os impactos dessas novas regulamentações fossem devidamente avaliados, não havendo qualquer análise sobre o custo que esses atos 
podem trazer à sociedade, aos consumidores, aos concessionários e a atração de novos investimentos para a indústria da eletricidade.

Referida resolução foi inclusive revisada em 2018 (Resolução Normativa nº 798/2018). Na revisão constaram pontos que fortaleceram a participação popular e a obrigatoriedade de implementação da AIR. Inclusive, nos atos normativos estudados pós revisão da Norma, se observou maior aplicabilidade do instrumento, no entanto, ainda sem a profundidade necessária.

\subsection{A AIR COMO PROCEDIMENTO}

Já foi explanado dentro da presente investigação que por AIR entende-se a ferramenta sistemática e analítica por meio da qual são avaliadas as opções regulatórias para determinado tema.

Em que pese a definição abrangente sobre o tema, Patrícia Valente (Valente, 2010, p. 54), é bem didática ao defini-lo. Segundo Valente, um tipo ideal de AIR contemplaria três grandes fases, quais sejam: “(i) o processo de tomada de decisão da medida regulatória, (ii) a implementação e (iii) o monitoramento da decisão". O processo como um todo, contemplaria ainda diversas subfases, as quais são apresentadas no quadro abaixo, adaptado de Casa Civil (2018). 
Tabela 1 - O processo de tomada de decisão da medida regulatória

\section{O PROCESSO DE TOMADA DE DECISÃO DA MEDIDA REGULATÓRIA}

1. Qual o problema regulatório a ser tratado

2. Qual a consequência de não correr qualquer intervenção

3. Quem é afetado pelo problema

4. Quais as alternativas possíveis para a solução do problema apresentado

5. Seleção de dados para análise do custo $\mathrm{x}$ benefício/custo $\mathrm{x}$ efetividade de cada uma das medidas

6. Análise e comparação das alternativas

7. Elaboração da AIR

8. Consulta Pública

9. Possível ajuste da AIR com base nos dados da consulta Pública

10. Tomada de decisão

11. Monitoramento da medida

Assim, como procedimento, a AIR seria um processo faseado e cíclico, que resultaria em uma importante e fundamental ferramenta de tomada de decisão.

A primeira subfase seria então relacionada a identificação do problema objeto do estudo. Ou seja, monitorado o mercado e identificada uma possível necessidade de intervenção para correção de uma distorção, se iniciaria o processo de realização da AIR. Já a segunda subfase é relacionada a necessidade de se observar quais os principais e mais evidentes efeitos de uma não intervenção na atividade estudada.

A terceira subfase se dedica a identificar quais os potenciais afetados pelo problema identificado e pela possível intervenção.

A subfase quatro, se dedica a verificar quais as possíveis alternativas se apresentam para o problema em questão. Nessa fase, todas as alternativas possíveis devem ser testadas, incluindo a alternativa de não regular o problema. 
A quinta subfase consiste na análise propriamente dita das alternativas encontradas. Nessa fase, o regulador deverá escolher um método para avaliar as alternativas encontradas, sendo os mais conhecidos, análise custo x benefício e a análise custo x efetividade.

A sexta subfase centra-se na comparação dos dados obtidos pelas análises realizadas. Nessa comparação serão avaliados os principais ônus e bônus de cada uma das alternativas até então avaliadas.

Todas essas fases, subsidiam a sétima subfase, que se concentra na elaboração propriamente dita da AIR. Nesse aspecto, quando da elaboração da AIR, o agente regulador quando da elaboração do documento, se utiliza de todas as informações antes coletadas nas fases anteriores, condensando-as em um único relatório, que servirá efetivamente de base para a tomada de decisão.

Já a oitava subfase se concentra em importante etapa da AIR: a Consulta Pública. É por meio da consulta pública que a população ou aos agentes econômicos afetados pela regulação em discussão tem a oportunidade de se manifestar efetivamente e contribuir com as ideias propostas pelo regulador. É de se lembrar que a um dos fatores que legitimam a necessidade de intervenção do estado nas atividades econômicas é justamente a assimetria de informações.

É dizer, as partes interessadas no desenvolvimento da atividade econômica possuem, por fatores intrínsecos ao próprio desenvolvimento da atividade, diferentes níveis de informações sobre referido exercício, nesse contexto a realização de consulta pública se torna parte primordial do processo de avaliação, visto que também é ferramenta que possibilita a diminuição dos diferentes graus de informações que possuem tanto o agente regulador como o agente regulado.

Mas, por óbvio, que a consulta pública realizada na subfase anterior não tem força vinculante, ou seja, ainda que um agente entenda que as alternativas propostas pela agência reguladora no âmbito da AIR não sejam de fato as melhores alternativas, tal contribuição não terá necessariamente de ser acatada pela agência reguladora. Essa análise a ser realizada de cada uma das contribuições relacionadas a AIR é parte da nona subfase do processo de AIR. 
No entanto, a não obrigatoriedade de acatamento das contribuições feitas por cada um dos agentes no campo da Consulta Pública, não afasta do agente regulador a obrigatoriedade de motivação de cada uma das recusas. Assim, em que pese o processo de consulta pública não seja de fato vinculante, de forma que o agente regulador não está vinculado a necessidade de acatamento das contribuições realizadas, tal fato não o exime de demonstrar explicitamente o motivo pelo qual cada uma das contribuições não pode de fato ser aceita.

Realizadas as devidas análises, a décima subfase centra-se na própria tomada de decisão do agente regulador. É nessa fase que o motivo pelo qual a AIR foi elaborado se materializa e é o momento no qual o agente regulador vai se utilizar de todas as análises, dados coletados e comparações realizadas para de fato tomar uma decisão sobre qual o caminho seguir.

Nesse contexto, de acordo com Valente, a tomada de decisão com base na AIR pode se dar e diversos níveis. Isso significa dizer que, quando da avaliação da AIR, o agente regulador poderá com base nos estudos realizados e dados coletados, desde a não intervenção regulatória quanto ao tema avaliado, ou mesmo, pelo simples ajuste de regulação existente, e até a completa mudança da regulação sobre o tema.

Por fim, realizada a tomada de decisão sobre determinado tema, é boa prática regulatória, recomendada inclusive pela OCDE (2009), a avaliação constante da medida implementada, sendo essa a última etapa da AIR, consistente na subfase 11.

Tal prática, denominada no Brasil como Monitoramento Regulatório ou mesmo Análise de Resultado Regulatório, concentra-se em reavaliar periodicamente a medida implementada, de modo que se verifique se, de fato, a regulação implantada obteve os efeitos desejados ou se há necessidade de ajustes posteriores.

Uma analogia inteligente sobre os efeitos da Análise de Resultado Regulatório é citada por Silva e Fonseca (2015 apud Brown e Stern Handbook for evaluating infrastructure regulatory systems. Washington: World Bank, 2006)". De acordo com os autores, "Brown e Stern (2006) fazem uma analogia da avaliação regulatória com o exame médico periódico, afirmando que são cada vez mais evidentes os benefícios obtidos com a atividade avaliativa".

\footnotetext{
${ }^{4}$ BROWN, Ashley C.; STERN, Jon; TENENBAUM, Bernard. Handbook for evaluating infrastructure
} regulatory systems. Washington: World Bank, 2006 
Ou seja, o monitoramento regulatório serve-se para evitar que os benefícios da AIR se percam com o tempo, de modo que os motivos pelos quais foi implementada a medida sejam reavaliados de tempos e tempos.

Assim, cumpridas todas as etapas, uma AIR, de acordo com as informações publicadas pela OECD deve ser capaz de responder algumas perguntas fundamentais, todas elencadas pelo comitê formador do PRO-REG, para que seja capaz de auxiliar no processo de tomada de decisão:

Figura 1 - Questões que devem ser respondidas por uma AIR.

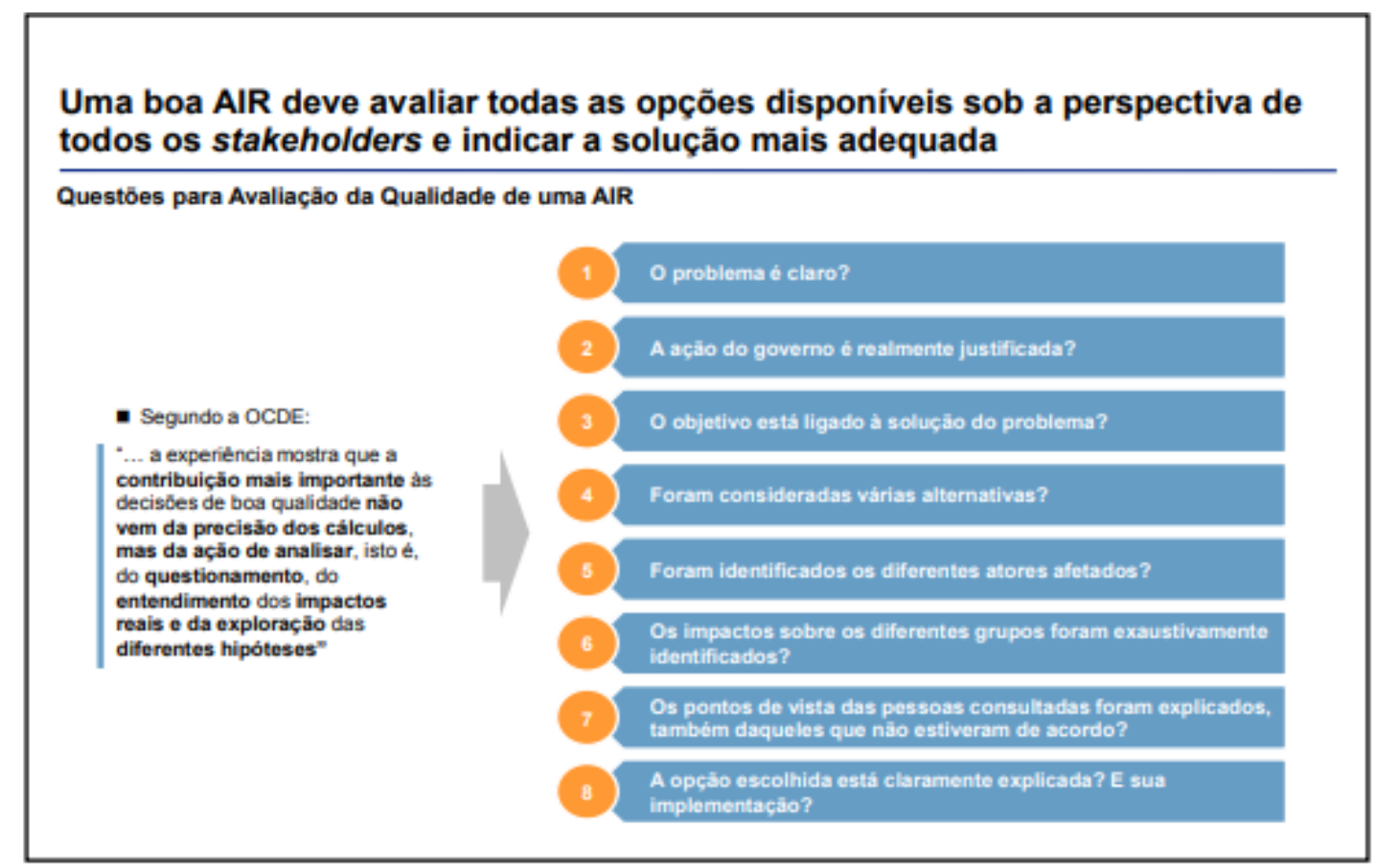

Fonte: PRO_REG

Desse modo, embora seja uma ferramenta de aplicação complexa, visto a necessidade de obtenção de grande variedade dados e análises econômicas, financeiras e sociais, se bem aplicada, é esperado que AIR revista o processo de tomada de decisão de: (i) transparência: em razão da participação social; (ii) Eficiência: em razão da tomada de decisão consciente com base em dados e análises críticas; (iii) responsabilização das autoridades que tomam a decisão baseada em dados concretos e análises. 
Além desses benefícios, a Anatel, por meio do Guia de Boas Práticas Regulatórias ${ }^{5}$ (2018 - apud ITU - Using Regulatory Impact Analysis to Improve Decision Making in the ICT 2014), também considera como benefício da ferramenta a possibilidade de reflexão do tomador de decisão sobre a real necessidade de regular determinado tema.

Diante disso, o processo de AIR, para que possua efetividade e cumpra com o seu papel de analisar as possibilidades regulatórias dentro de um contexto que se pretende intervir, não deve ser enxergado como um simples preenchimento de formularia, mas sim como uma análise, reflexão e execução de coleta de dados completa e abrangente. Tal fato, é inclusive destacado pela Anatel, em seu Guia de Boas Práticas Regulatórias (2018, p.24)

\footnotetext{
A AIR não deve ser entendida como um questionário ou uma lista de itens a ser preenchida para justificar a criação de uma regulação. Para que sirva a seu propósito, deve de fato consistir em um processo de diagnóstico do problema, reflexão sobre a necessidade da regulação e de investigação sobre a melhor forma de realizá-la.
}

Concluindo, como processo, podemos classificar a AIR como um processo sistemático, faseado, complexo e analítico que se utilizando de métodos de análise econômica pode auxiliar na verificação e quantificação da melhor medida regulatória a ser tomada para determinado problema identificado, o qual, se aplicado corretamente, pode oferecer benefícios relacionados a transparência, eficiência, responsabilização e menor grau de intervenção regulatória considerada desnecessária.

\subsubsection{Os métodos de avaliação para elaboração da AIR.}

Como já mencionado anteriormente, a Análise de Impacto Regulatório, se conceitua como um verdadeiro instrumento de governança regulatória ${ }^{6}$, que permite avaliar tecnicamente as alternativas existentes para um determinado problema regulatório, permitindo que o agente regulador, diante do problema posto, possa tomar decisões pautado em dados reais e técnicos, o que impede, por vezes, a captura da decisões por interesses externos.

\footnotetext{
${ }^{5}$ ITU - Using Regulatory Impact Analysis to Improve Decision Making. ICT. 2014

6 “Governança Regulatório é o desenvolvimento sistemático e a implementação de políticas gerais sobre como o governo utiliza seus poderes regulatórios (OECD, 2003).
} 
Mas essa avaliação exige certo grau de tecnicidade, em especial para consolidação e interpretação dos dados, de modo que se possa comparar os efeitos de cada uma das alternativas regulatórias existentes para o problema em análise.

Nesse contexto, a AIR para consolidação e interpretação dos dados, pode se valer de métodos econômicos e analíticos de valoração dos benefícios trazidos por cada uma das alternativas. Assim, nesse item, pretende-se pormenorizar alguns dos métodos mais difundidos e utilizados no âmbito da confecção da AIR, quais sejam: (i) análise custo x benefício; (ii) análise custo x efetividade; (iii) análise multicritério.

Vale dizer que existem muitos outros métodos de avaliação de impacto regulatório, além disso, os métodos ora avaliados podem ser utilizados em diferentes níveis de complexidade, a depender da abrangência e complexidade do problema avaliado.

\subsubsection{A análise custo $\mathrm{x}$ benefício}

De acordo com a OECD (2008), a análise custo benefício é realizada em praticamente todas as Análises de Impacto Regulatório realizadas e, de acordo com Oliveira (2015) foi sistematizada no direito norte americano pelo Decreto Executivo ${ }^{\circ} 12.291$

Em linhas geras, nos termos do quanto definido pela OECD (2008) a análise custo benefício, como critério de avaliação da medida regulatória a ser implementada consiste na atribuição de valor monetário à todas, ou praticamente todas, as variáveis mais importantes da medida estudada, de modo a comparar se os custos envolvidos na regulação a ser implementada não superam de alguma forma os benefícios pretendidos com a implementação daquela intervenção.

Nesse sentido, ainda de acordo com Oliveira (2015), a análise custo x benefício consiste em um modelo de avaliação que pressupõe, por parte do regulador, a identificação dos efeitos positivos e negativos de uma medida regulatória.

No mesmo contexto, Valente (2010) define a análise custo benefício dentro de uma avaliação de impacto regulatório como um método por meio do qual se calcula a quantidade total de benefícios em detrimento da quantidade de custos atrelados a essa mesma decisão 
regulatória. Ainda nas palavras de Valente (2010), caso o total dos custos atribuídos a implantação de uma intervenção regulatória seja inferior a quantidade de benefícios atribuídos a tal medida, a implantação dessa medida pode tornar-se viável.

Salgado e Borges (2010) também explicitam que é importante ter em conta que nem sempre os custos e benefícios relacionados a implementação de uma regulação são monetizáveis. Isso não significa, no entanto, que tais impactos devem ser desconsiderados na análise custo benefício, de modo que, em sendo impossível a sua mensuração, deve-se adotar, no mínimo uma descrição qualitativa dos custos e benefícios envolvidos.

Ao analisar a aplicabilidade prática da análise custo benefício dentro do processo de tomada de decisão, Valente (2010) se utiliza de um exemplo muito didático para exemplificar em que consistiria exatamente uma análise custo benefício realizada para a implantação de uma medida regulatória.

Nesse contexto, Valente nos convida a imaginar a seguinte situação concreta: (i) uma determinada via pública em que há grande congestionamento de veículos durante o dia com má organização do trânsito local; e (ii) a mesma via pública durante a noite, em que há elevado número de acidentes com pedestres.

Ainda no mesmo exercício didático, Valente supõem a existência de quatro alternativas regulatórias para o problema: (i) colocação de semáforos; (ii) lombadas de concreto; (iii) semáforos com contador de segundos; (iv) colocação de radares eletrônicos.

Cada uma das alternativas, de acordo com Valente, apresenta uma determinada composição de custos $\mathrm{x}$ benefício, podendo ser interpretadas isoladamente ou em conjunto com as demais alternativas.

Para resolução do problema, o necessário seria a adoção de uma alternativa que, além de ser capaz de aliviar o congestionamento de veículos, também auxiliasse na diminuição de acidentes com pedestres durante o período noturno, ao menor custo.

Continuando em sua explanação, Valente pressupõe que a melhor alternativa envolveria as alternativas (iii) e (iv), já que organizaria o trânsito no local, auxiliando os pedestres na 
travessia, como também reverteria benefícios econômicos para a administração pública com a arrecadação de multas de administrados que eventualmente viessem a transgredir as normas de trânsito locais.

Assim, a combinação dessas alternativas, além de chegarem a desejada diminuição do tráfego com a organização do trânsito local, também permitem a arrecadação estatal, de forma que os custos com a instalação dos equipamentos, projetos, etc, são superados como os benefícios alcançados pela medida.

O exemplo, bastante ilustrativo, demonstra a valoração dos atributos de cada medida regulatória, de modo a deixar clara a intenção do método.

No entanto, há que se ressaltar que nem sempre, a valoração monetária dos atributos das alternativas regulatórias é suficientemente clara, o que pode tornar a medida excessivamente custosa. Em que pese tal dificuldade, a alternativa de análise não deve ser descartada em especial quando se está diante de recursos finitos para numerosas demandas regulatórias, como bem pontua Valente (2010).

\subsubsection{Análise custo $\mathrm{x}$ efetividade}

Outro método de avaliação mais comumente utilizado em AIR é a análise custo efetividade. De acordo com a OECD (2008), a análise custo efetividade é uma forma mais simples de avaliação dos potenciais benefícios a serem auferidos com uma medida regulatória a ser implementada. Isso porque, enquanto na análise custo benefício há necessidade de monetização tanto dos custos envolvidos quando dos benefícios a serem alcançados, na análise custo x efetividade, não há necessidade de valoração dos benefícios a serem alcançados, mas apenas dos custos envolvidos.

A metodologia, no entanto, como abordado pela própria OECD (2008), não permite avaliar se se deve regular, de modo que deve ser utilizada apenas nas hipóteses em que já há definição clara da necessidade de regular e dos benefícios que se pretende alcançar com a regulação ser implementada. 
Nesse contexto, Oliveira (2015, p.275) sintetiza de maneira bem clara qual seria então o real objetivo da análise custo efetividade: “a análise, portanto, é centralizada nos custos, devendo ser eleita a medida que alcança o benefícios predeterminado como menor custo possível”.

Ou seja, enquanto a análise custo benefício permite uma avaliação de "o que fazer", determinando em termos monetários qual seria a melhor relação custo benefício entre diversas maneira de se tratar um mesmo tema, incluindo os possíveis benefícios esperados de cada uma das medidas, a analise custo efetividade auxilia no "como fazer", visto que se parte da análise de diversas possibilidades atribuíveis a solução de um problema, para chegada em um benefício já pré-definido ${ }^{7}$. (Oliveira, 2015 apud Jacobs, Sccott H. Current Trends in Process and Methods of Regulatory Impact Assessment: Mainstreaming RIA into Policy Process, p.30).

\subsubsection{A análise multicritério}

Outro método econômico de avaliar qual das alternativas a ser implementada atenderia melhor aos interesses que se pretende, é a análise multicritério.

O OECD (2008, p.14) considera a análise multicritério como uma metodologia que permite a avaliação das decisões ainda que a quantificação monetária dos custos envolvidos e dos benefícios a serem alcançados não se demonstram possíveis.

Multi-Criteria Analysis (MCA) is a methodology that allows systematic and transparent decisions to be made even where quantification of major regulatory impacts is not possible.

MCA involves identifying the underlying policy objectives and then determining all of the factors (the criteria) that would indicate achievement of these objectives.

Assim, pela análise multicritério, a cada política possível para o alcance de um objetivo, são atribuídos pontos ou valores que ao final se somam para identificar qual a melhor medida a ser implementada.

7 Jacobs, Sccott H. Current Trends in Process and Methods of Regulatory Impact Assessment: Mainstreaming RIA into Policy Process. In KIRKPATRIC CK, Colim PARKER, David (coords) Regulatory Impact Assesment: towards Better Regulation? Massachusetts: Edward Elgar, 2007. 
A própria OECD (2008), quando da avaliação do conceito da análise multicritério, traz um exemplo bastante elucidativo que demonstra em que consistiria, na prática, tal análise. No caso em questão, um determinado governo buscava soluções que permitissem melhorar a saúde bucal de uma população, na análise foram considerados cinco critérios distintos, os quais foram sopesados para que se chegasse na melhor alternativa.

Figura 2 - Análise Multicritério

\begin{tabular}{|l|l|l|l|l|}
\hline Criterion & Weighting & $\begin{array}{l}\text { Fluoride } \\
\text { regulation }\end{array}$ & $\begin{array}{l}\text { Advertising } \\
\text { campaign }\end{array}$ & $\begin{array}{l}\text { Free dentist } \\
\text { visits }\end{array}$ \\
\hline $\begin{array}{l}\text { Effectiveness in improving dental } \\
\text { health }\end{array}$ & 4 & $5(20)$ & $3(12)$ & $3(12)$ \\
\hline $\begin{array}{l}\text { Ability to address existing dental } \\
\text { problems }\end{array}$ & 2 & $0(0)$ & $1(2)$ & $5(10)$ \\
\hline $\begin{array}{l}\text { Ability to improve dental health of } \\
\text { the poorest groups }\end{array}$ & 2 & $4(8)$ & $2(4)$ & $5(10)$ \\
\hline $\begin{array}{l}\text { Ability to improve health in all } \\
\text { regions }\end{array}$ & 1 & $5(5)$ & $5(5)$ & $3(3)$ \\
\hline Cost $^{2}$ & 4 & $5(20)$ & $4(16)$ & $2(8)$ \\
\hline Score & & $\mathbf{5 3}$ & $\mathbf{3 9}$ & $\mathbf{4 3}$ \\
\hline
\end{tabular}

Fonte: OECD (2008)

No exemplo, para três possibilidades distintas para a implementação de um a política que possibilitasse a melhora da saúde bucal de uma determinada população, foram avaliados cinco critérios, sendo que para cada um deles, foi atribuído um peso diferente. Pela análise multicritério, a alternativa cuja soma dos pesos seja a maior, no caso em questão, a regulamentação sobre a adição de flúor a água utilizada pela população em geral, é que a demonstrou os melhores resultados, e, portanto, é a que em tese deveria prosseguir.

\subsubsection{A consulta pública na AIR}

Quando da análise das subfases da Análise de Impacto Regulatório, destacou-se a necessidade de se realizar consulta pública como importante etapa de coleta de informações e percepção do agente regulador sobre as expectativas quanto a implantação de determinada regulação.

Nesse contexto, e tendo em vista que o objetivo da presente investigação cientifica também é o de avaliar a utilização da consulta pública como uma ferramenta de validação e eficiência do processo de AIR, importante destacar algumas características do referido instituto. 
A consulta pública, nesse cenário, se revela como verdadeiro processo de democracia participativa, diminuindo a assimetria de informações entre regulador e regulado (típica de ambientes regulados) e permitindo que o regulado participe efetiva e ativamente como ator do processo decisório

Por consulta pública, como procedimento de tomada de decisão, de acordo com Melo (2016, p.41), entende-se:

A audiência pública na função administrativa é um processo administrativo cujo objetivo é ouvir segmentos a sociedade antes da formulação de uma política pública ou da tomada de uma decisão e, com isso, contribuir para: (i) a legitimidade da atuação estatal no exercício da função administrativa; (ii) a construção conjunta da melhor decisão possível; (iii) o fortalecimento da autonomia pública dos cidadãos por meio da participação democrática no processo de formação da decisão e vontade e (iv) aperfeiçoamento da transparência e do controle social da ação estatal.

Ou seja, no âmbito administrativo, no qual se insere a atividade regulatória, a consulta pública é um processo que permite, além da legitimação da decisão advinda daquele processo, uma construção da melhor solução em parceria como afetado.

Sobre esse ponto, inclusive, a OECD (2008), analisando a consulta pública no contexto da AIR, entende a subfase como essencial para obtenção de dados reais sobre o tema em estudo, bem como para legitimar uma futura decisão a ser tomada sobre o tema.

Ainda sobre a necessidade de realização da consulta pública como fase da AIR, Casa Civil (2018) também prevê a subfase como essencial a elaboração da AIR.

Como processo em si, a consulta pública nada mais é que do que permitir, seja pela participação oral ou até mesmo pelo envio de documentação, a manifestação de opinião popular, em geral dos afetados ou interessados no tema, para que esses explicitem preocupações, divergências, concordância ou mesmo sugestão de melhoria das alternativas propostas, incluindo, inclusive, novas alternativas que não as indicadas.

Nesse contexto, como parte do processo de avaliação da melhor alternativa regulatória a ser implementada, a consulta pública é parte importante do processo da AIR, tendo em vista 
a necessidade de coleta de dados real e a legitimação da decisão a ser tomada posteriormente pela autoridade regulatória.

\subsubsection{Possíveis classificações da AIR}

Como procedimento, já foi exposto que de acordo com as OECD e com a definição de Valente (2010), a Análise de Impacto Regulatório é um processo sistemático e analítico que auxilia no processo de tomada de decisão do regulador de modo a permitir que a avaliação da melhor opção regulatória associada a determinado tema.

Como ferramenta de tomada de decisão a AIR é então composta por diversas subfases que permitem a identificação do problema e a coleta de dados para real avaliação de sua extensão e posterior decisão. Mas, em que pese até o momento se tenha avaliado a ferramenta como um processo faseado, não houve classificação quanto a sua aplicação e abrangência.

Nesse contexto, a OECD, trata da AIR de forma mais geral, não classificando-a em níveis de complexidade e aplicação. Oliveira (2015), no entanto, é bastante didático ao classificar a abrangência de aplicação da AIR

Assim, em termo de abrangência, Oliveira (2015) classifica a aplicação da AIR em análises gerais e análises parciais.

Por análises gerais de AIR entendem-se aquelas em que possíveis impactos a todo um sistema econômico e a todos os setores da economia são efetivamente avaliados pela AIR realizada. Já as análises parciais de AIR são aquelas em que apenas os impactos a um setor da econômica são avaliados para fins de tomada de decisão.

Quanto a obrigatoriedade, o mesmo autor classifica as análises como obrigatórias ou facultativas, indicando que a obrigatoriedade de realização da AIR é variável de acordo com regras específicas de cada um dos agentes reguladores. 


\subsection{A EXPERIÊNCIA INTERNACIONAL: IMPLEMENTAÇÃO DA AIR NOS ESTADOS UNIDOS E NA UNIÃO EUROPEIA}

Como já mencionado, os primórdios do que hoje se entende efetivamente como análise de impacto regulatório teve sua origem nos Estados Unidos, com o já mencionado Executive Order (decreto, tradução nossa) n 12.291/1981.

Já na União Europeia, o Livro Branco sobre Governança Europeia, de 2001, institucionalizou a AIR classificando-a como uma ferramenta de governança regulatória que auxilia na tomada de decisão que permita com que a política a ser implementada chegue ao benefício esperado.

\subsubsection{AIR nos Estados Unidos}

Nos Estados Unidos, conforme detalha Oliveira (2015), a AIR como procedimento sistematizado foi inserida no Executive Order, ou decreto, em tradução livre nº 12.291 de 1981.

Referido Decreto, o qual foi editado em um contexto de aumento da governança regulatória nos Estados, sistematizou o processo de Análise de Impacto Regulatório para a tomada de decisões regulatórias.

Oliveira (2015) ao discorrer sobre os principais objetivos dessa regulamentação entendeu que essa tinha como objetivo principal reduzir encargos das regulações a serem implementadas e evitar conflitos de normas.

Além da implementação positivada desses objetivos principais, o Decreto também estabeleceu quais as normas de cunho regulatório (major rules) deveriam obrigatoriamente ser precedidas de AIRo, classificando-as como: (i) normas que produzam impactos econômico igual ou superior a 100 milhões de dólares; (ii) que produzam aumento significativo dos custos ou preços para os consumidores, industrias, localizações geográficas ou agências federais ou estaduais; (iii) significativo efeito adverso sobre a concorrência, emprego, produtividade, inovação. 
Como procedimento, o Decreto ainda estabeleceu que a AIR deveria ser construída, para as normas acima apresentadas, com a observância dos seguintes passos:

(i) Cada agência deve estabelecer quais as normas a serem implementadas caracterizam-se no conceito de major rules;

(ii) Cada Análise de Impacto Regulatório elaborada, deve ser publicada com antecedência

(iii) Cada Análise de Impacto Regulatório de, pelo menor, conter os seguintes requisitos: (a) descrição dos benefícios potenciais da regra; (b) descrição dos custos potenciais da regra; (c) abordagens regulatórias alternativas que poderiam alcançar os mesmos objetivos; (d)

Por meio do referido decreto então, foram estabelecidas as bases da AIR. No entanto, em 1993, por meio da publicação do 12.866 (Regulatory Planning and Review) o Decreto 12.291 foi revogado

Em que pese a revogação do Decreto que inaugurou nos Estados Unidos a estruturação da AIR, gato é que o Decreto 12.866 também previu a necessidade de que cada ação regulatória implementada previsse os custos e benefícios atrelados a política regulatória, bem como quais as opções regulatórias disponíveis para o problema avaliado:

\footnotetext{
"In deciding whether and how to regulate, agencies should assess all costs and benefits of available regulatory alternatives, including the alternative of not regulating.Costs and benefits shall be understood to include both quantifiable measures (to the fullest extent that these can be usefully estimated) and qualitative measures of costs and benefits that are difficult to quantify, but nevertheless essential to consider. (Estados Unidos da América, Executive Order 12.866/1993)
}

Posteriormente, foi publicado o Decreto 13.563/2011, que reafirmou os princípios e a necessidade de realização da AIR anteriormente a intervenção regulatória. Nesse contexto Oliveira (2015) destaca que tal decreto teve fundamental papel em reafirmar o importante papel da participação da população popular no processo de tomada de decisão, reconhecendo que a eficiência regulatória "depende da ampla participação e análise qualitativa e quantitativa dos custos e benefícios envolvidos. 
Recentemente no evento Conferência Internacional - Análise de Impacto Regulatório: experiência dos EUA, promovido pela Escola Nacional de Administração Pública (ENAP), com o apoio do Banco de Desenvolvimento da América Latina, o professor Kerry Krutilla ${ }^{8}$,conclui que, embora haja necessidade de aprimoramento no modelo, a Análise Impacto Regulatório é bastante institucionalizada e utilizada nos Estados Unidos

\subsubsection{AIR na União Europeia}

Já na União Europeia ${ }^{9}$, os primeiros indícios de institucionalização da AIR foram formatados no Livro Branco de Governança Europeia.

Em citado documento, os estados membro da União Europeia elencam os cinco princípios que devem ser perseguidos quando das relações no âmbito da União Europeia.

(iv) Abertura: maior transparência na comunicação de suas decisões;

(v) Participação: oportunizar a participação da sociedade na elaboração e aplicação de políticas públicas

(vi) Responsabilização: atribuir claramente as autoridades governamentais o seu papel na tomada de decisão.

(vii) Eficácia: decisões devem ser tomadas no momento adequado para que surtam os efeitos desejados

(viii) Coerência: esforço conjunto para que as decisões e políticas adotadas no âmbito da União Europeia.

Além desses cinco princípios, o Livro Branco também estabeleceu, de acordo com Oliveira (2015, p.284)

Reforço da participação dos cidadãos no debate público; b) melhores política, melhor regulamentação e melhores resultados, com a proposta, inclusive, de criação de novas agências com independência e competência técnica; c) contribuição da União Europeia para a governança global, reforçado a sua

\footnotetext{
${ }^{8}$ Disponível em: https://www.gov.br/casacivil/pt-br/assuntos/governanca/regulacao/eventos/2018/conferencia-internacional2013-analise-de-impacto-regulatorio-experiencia-dos-eua/conferencia-internacional-2013-analise-de-impacto-regulatorioexperiencia-dos-eua

99 A União Européia é formada pelos seguintes países: Alemanha, Austria, Bélgica, Bulgaria, Chéquia, Chipre, Croácia, Dinamarca, Eslováquia, Eslovênia, Espanha, Estônia, Finlândia, França, Grécia, Hungria, Irlanda, Itália, Letônia. Lituânia, Luxembutgo, Malta, Paises Baixos, Polônia, Portugal, Romênia, Suécia. Fonte: https://europa.eu/european-union/abouteu/countries_pt
} 
posição no cenário mundial; e d) redefinição das políticas, com identificação de forma clara de seus objetivos de longo prazo, bem como das funções das instituições europeias.

Ou seja, em que pese a AIR propriamente dita não tenha sido citada como boa prática de governança regulatória no Livro Branco, é certo que seus princípios estavam ali inseridos.

Posteriormente, em junho de 2002, a comissão europeia, por meio da publicação do comunicado "plano de ação - simplificar e melhorar o ambiente regulador propôs a aplicação da avaliação de impacto para implementação de políticas. No mesmo período também foi publicado comunicado "Comunicação da comissão sobre a avaliação de impacto cuja pretensão foi a de a comissão europeia publicou comunicado que cuja pretensão era a de "lançar a avaliação de impacto enquanto instrumento destinado a melhorar a qualidade e a coerência do processo de elaboração de políticas “.

Esse segundo comunicado, estipulou, conforme sintetizado por Oliveira (2015, p.285):

“a) avaliação preliminar : avaliação do problema, das eventuais opções e dos setores afetados, permitindo a seleção das propostas que serão objeto de uma avaliação definitiva; e b)avaliação exaustiva: as propostas selecionadas para uma avaliação exaustiva são aquelas que acarretam uma reforma política importante ou impactos econômicos, ambientais e/ou sociais significativos"

De acordo com dados publicados pela OECD (2019) todos os Estados membro da União europeia adotam a AIR em algum nível. Os níveis de aplicação da AIR são sintetizados na figura abaixo: 
Figura 3 - Aplicação da Análise de Impacto Regulatório na União Europeia
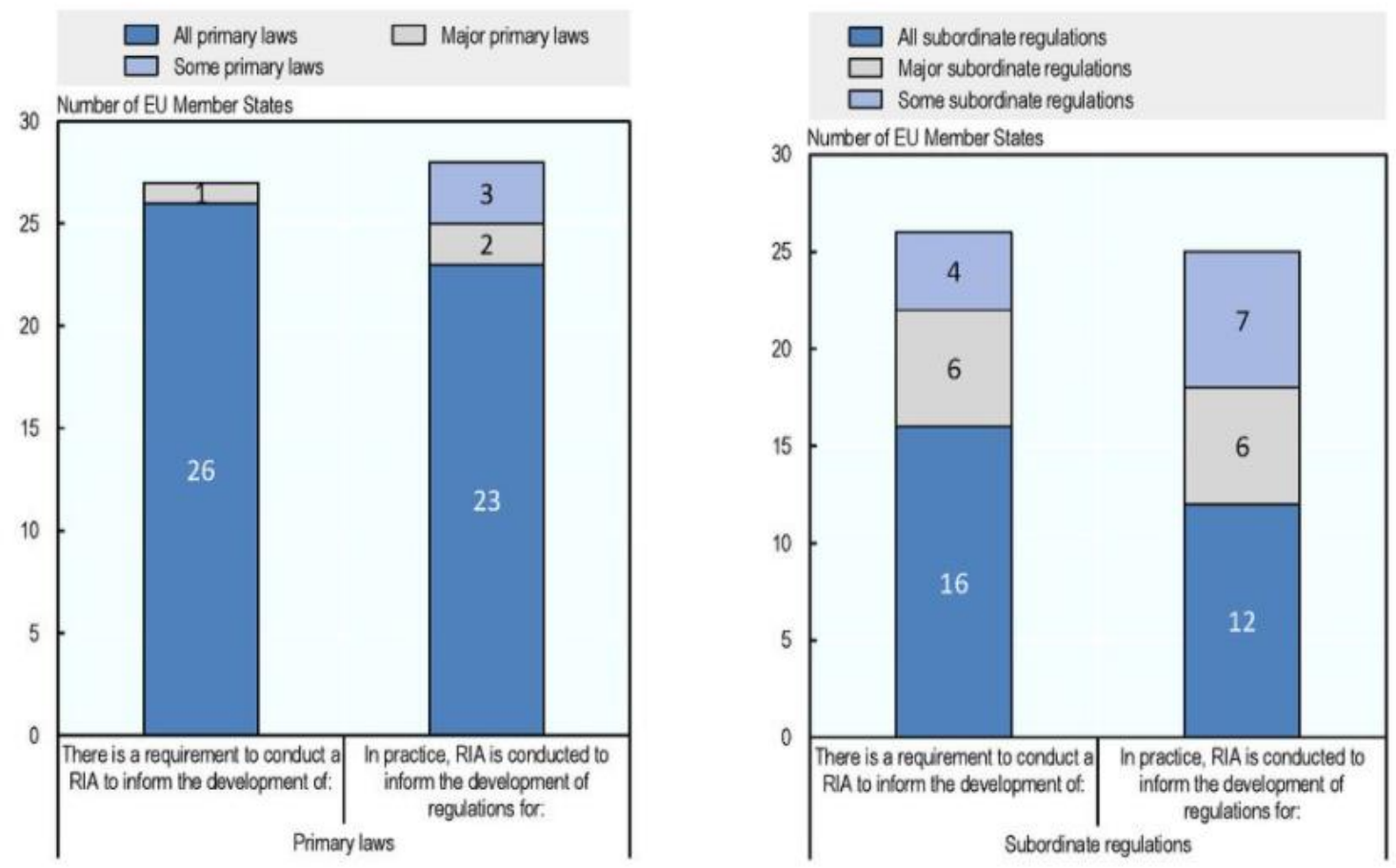

Note: Data is based on 28 EU Member States.

Source: Indicators of Regulatory Policy and Governance Surveys 2017, http://oe.cd/ireg.

Fonte: OECD (2019)

\subsection{O CASO BRASILEIRO: A IMPLEMENTAÇÃO DA AIR NO BRASIL}

No Brasil, a AIR como instrumento de tomada de decisão e governança é recente, tendo sido introduzida de modo mais intensificado e explicito somente a partir da publicação da Declaração dos Diretos da Liberdade Econômica, publicada pela Lei 13.874/2019 e da Lei das Agências Reguladoras (Lei 13.848/2019).

Em que pese tal fato, pode-se considerar como uma forma inicial de AIR a publicação do Decreto 4.176/2002 o qual estabelece normas e diretrizes para a elaboração, a redação, a alteração, a consolidação e o encaminhamento ao Presidente da República de projetos de atos normativos. Referido Decreto previu em seu anexo I que a cada ato enviado ao Presidente da República deveriam ser respondidas perguntas relacionadas ao objetivo perseguido pela lei, motivo pelo qual seria necessária a intervenção além de possíveis intervenções que poderiam ocorrer em razão da publicação da medida. 
No entanto, foi a partir da publicação do PRO_REG que a temática relacionada a governança regulatória e necessidade de adoção de medidas de qualidade da regulação passaram a ser incentivadas e implementadas no âmbito regulatória brasileiro.

Assim, o PRO_REG foi instituído por meio do Decreto 6.062/2007, com o objetivo principal de "contribuir com a melhoria do sistema regulatório, da coordenação entre as instituições que participam do processo regulatório exercido no âmbito do Governo Federal, do mecanismo de prestação de contasse de participação e monitoramento por parte da sociedade civil e da qualidade da regulação de mercados"

O programa, que consistiu em parceria da Casa Civil com o Banco Interamericano de Desenvolvimento, consistiu em uma seria de análise e estudos que visavam o fortalecimento do cenário regulatório brasileiro. Nas palavras da própria Casa Civil (2018) o PRO_REG em sua primeira fase promoveu estudos, treinamentos e análise viltadas a melhoria da qualidade regulatória no Brasil.

Dentre os estudos e projetos desenvolvidos, e na forma citada por Oliveira (2015), uma das iniciativas desenvolvidas no âmbito do programa foi a implementação de projeto piloto relacionado a inserção da AIR na Anvisa.

O mencionado projeto piloto resultou na publicação da Portaria Anvisa n 422/2008 a qual "Institui o Programa de Melhoria do Processo de Regulamentação no âmbito da Agência Nacional de Vigilância Sanitária e dá outras providências" inaugurando oficialmente no Brasil a utilização pública da ferramenta AIR como um método a ser utilizado na tomada de decisão.

Em termos gerais, a Portaria $\mathrm{n}^{\circ} 422 / 2008$ estabeleceu a diretrizes para o fortalecimento do processo regulatório no âmbito da Agência, como fortalecimento da capacidade institucional, melhoria da coordenação, da qualidade e da efetividade da regulamentação, fortalecimento da transparência

Nesse contexto, ainda em 2008, com o objetivo de fortalecer o ambiente regulatório nos termos da Portaria publicada, foi publicado o Guia de Boas Práticas Regulatórias, o qual menciona expressamente a necessidade de utilização da AIR como um instrumento de tomada 
de decisão que proporciona ação regulatória mais eficiente, visto que permite a análise de riscos e prevê os resultados relativos as medidas que se pretende implementar.

Instituído a AIR na Anvisa, diversas outras Agências Reguladoras iniciaram a implementação da ferramenta como método de auxílio na tomada de decisão, conforme se verifica do quadro a seguir

Tabela 2 - Resumo da implementação da AIR nas Agências Reguladoras Brasileiras.

\begin{tabular}{|c|c|c|}
\hline $\begin{array}{c}\text { Agência } \\
\text { Reguladora }\end{array}$ & Ato instituidor da AIR & Última atualização sobre AIR \\
\hline ANVISA & $\begin{array}{l}\text { Portaria 422/2008 } \\
\text { (posterior publicação do } \\
\text { Manual de Boas } \\
\text { Regulatórias com previ } \\
\text { são específica da AIR) }\end{array}$ & $\begin{array}{l}\text { Publicado em } 2019 \text { o Guia de Análise de Impacto } \\
\text { Regulatório, em atenção as diretrizes constantes } \\
\text { da Portaria } n^{\circ} 1.741 / 2018\end{array}$ \\
\hline ANAC & $\begin{array}{l}\text { Instrução Normativa } n^{\circ} \\
61 / 2012\end{array}$ & $\begin{array}{l}\text { Publicado em } 2020 \text { a Instrução Normativa } n^{\circ} \\
154 / 2020 \text { com determinação de realização da } \\
\text { Análise de Impacto Regulatório para edição de } \\
\text { atos de caráter normativo }\end{array}$ \\
\hline ANCINE & $\begin{array}{l}\text { Resolução da Diretoria } \\
\text { Colegiada } \mathrm{n}^{\circ} 52 / 2013\end{array}$ & $\begin{array}{l}\text { Alterada pela Resolução da Diretoria Colegiada } \\
n^{\circ} 81 / 2018 \text {, contendo a obrigatoriedade de } \\
\text { realização da análise de impacto regulatório }\end{array}$ \\
\hline ANEEL & $\begin{array}{l}\text { Resolução Normativa } n^{\circ} \\
540 / 2013\end{array}$ & $\begin{array}{l}\text { Resolução Normativa } n^{\circ} \quad 798 / 2017, \text { com } \\
\text { ampliação da AIR }\end{array}$ \\
\hline ANATEL & Resolução 612/2013 & $\begin{array}{l}\text { Publicada Resolução 927/2015 com } \\
\text { especificações relacionadas a elaboração da AIR } \\
\text { Em } 2018 \text { foi publicado Manual de Boas Práticas } \\
\text { Regulatórias, contendo instruções para realização } \\
\text { de uma AIR considerada ideal para os padrões da } \\
\text { Agência }\end{array}$ \\
\hline ANP & $\begin{array}{l}\text { Primeira AIR realizada } \\
\text { pela Agência em 2013, } \\
\text { ainda que sem norma } \\
\text { específica }\end{array}$ & $\begin{array}{l}\text { Portaria } \mathrm{n}^{\circ} 265 / 2020 \text { que define o regimento } \\
\text { interno da ANP determina a realização da AIR } \\
\text { nos casos de "ações regulatórias da ANP, cabíveis } \\
\text { diante da identificação de um problema } \\
\text { regulatório pertinente às suas competências, serão } \\
\text { precedidas de Análise de Impacto Regulatório - } \\
\text { AIR." }\end{array}$ \\
\hline ANTT & $\begin{array}{lr}\text { Em } 2013 \text { foram } \\
\text { iniciados } & \text { estudos } \\
\text { envolvendo uma espécie } \\
\text { de AIR Regulatório } \\
\text { simplificada. }\end{array}$ & $\begin{array}{l}\text { Em } 2020 \text { foi publicado Manual de Análise de } \\
\text { Impacto Regulatório }\end{array}$ \\
\hline
\end{tabular}




\begin{tabular}{|c|c|c|}
\hline $\begin{array}{l}\text { Agência } \\
\text { Reguladora }\end{array}$ & Ato instituidor da AIR & Última atualização sobre AIR \\
\hline ANTT & $\begin{array}{l}\text { Em } 2013 \text { foram iniciados estudos } \\
\text { envolvendo uma espécie de Análise } \\
\text { de Impacto Regulatório } \\
\text { simplificada, ainda que não } \\
\text { houvesse resolução específica sobre } \\
\text { o tema }\end{array}$ & $\begin{array}{l}\text { Em } 2020 \text { foi publicado Manual de } \\
\text { Análise de Impacto Regulatório }\end{array}$ \\
\hline ANTAQ & $\begin{array}{l}\text { Utilizado, ainda que sem } \\
\text { regulamentação, para publicação da } \\
\text { portaria trata de taxa para terminais } \\
\text { para uso de espelho d'água }\end{array}$ & $\begin{array}{l}\text { Norma que regulamenta a AIR está } \\
\text { em Audiência Pública - Audiência } \\
\text { Pública } \mathrm{n}^{\circ} 05 / 2020 \text {. A norma pretende } \\
\text { prever em quais casos deve } \\
\text { obrigatoriamente ser aplicada a AIR }\end{array}$ \\
\hline ANA & $\begin{array}{l}\text { Primeira publicação verificada em } \\
2019\end{array}$ & $\begin{array}{l}\text { Resolução 76/2019 - regimento } \\
\text { interno da ANA previu a realização da } \\
\text { Análise de Impacto Regulatório para } \\
\text { elaboração de atos de caráter } \\
\text { normativo }\end{array}$ \\
\hline ANS & $\begin{array}{l}\text { Inserido no regimento interno por } \\
\text { meio da Resolução Normativa } n^{\circ} \\
331 / 2013\end{array}$ & - \\
\hline
\end{tabular}

Fonte: Informações adaptadas e atualizadas de Oliveira (2015).

Como pode ser observado da planilha resumo, a AIR foi amplamente adotada no âmbito das agências reguladoras, sendo parte do processo de tomada de decisões dessas Agências.

No entanto, o tema no Brasil continuou a ser explorado, estudado e aprimorado, sendo que em 2012, a OECD publicou relatório sobre recomendações do conselho sobre política regulatória e governança.

Tal relatório, elaborado e publicado pelo Comitê de Política Energética da OECD, tem como objetivo auxiliar países membros e não membros a construir e fortalecer o ambiente regulatório, apresentando ações que devem ser tomadas por esses países que que seja atingido tal objetivo.

Dentro outras políticas indicadas com o objetivo principal de fortalecer as instituições reguladoras, o relatório indicou como boa prática a ser perseguida a implementação da AIR ainda que nas etapas iniciais da regulação (OECD, 2012, p 10). 
Integrar a Avaliação do Impacto Regulatório (AIR) desde os estágios iniciais do processo de políticas para a formulação de novas propostas de regulação. Identificar claramente os objetivos da política, e avaliar se a regulação é necessária e como ela pode ser mais efetiva e eficiente na consecução desses objetivos. Considerar outros meios de regulação e identificar os trade-offs das diferentes abordagens analisadas para escolher a melhor alternativa.

Em que pese o referido relatório não ter força legal do Brasil, tal documento fomentou os estudos relacionados à AIR.

Em 2017, foi aberta pela Casa Civil, Consulta Pública para discussão de um guia que consistiria em um documento base para elaboração de AR no âmbito brasileiro cujo resultado foi a publicação, em 2018, do documento "Diretrizes Gerais e Guia Orientativo para Elaboração de Análise de Impacto Regulatório - AIR”.

O principal foco do documento é estabelecer diretrizes gerais para que que as Agências Reguladoras pudessem adotar o instrumento.

De forma sistemática, o Guia propõe:

Tabela 3 - Modelo de AIR.

\section{Tema $\quad$ Diretriz}

Vinculação Guia de natureza orientativa e não vinculativa

Quando realizar a Assim que identificado um problema regulatório que necessite de AIR intervenção

Possíveis

(i) Atos normativos de natureza administrativa que afetem apenas o hipóteses de funcionamento interno e burocrático da Agência Reguladora; dispensa da AIR (ii) Atos normativos de efeito concreto;

(iii) Atos normativos que visem corrigir meros erros de forma (ortografia, pontuação, numeração de normas);

(iv) Atos normativos que visem consolidação de normas sem alteração de mérito;

(v) Atos normativos que visem revogação de normas obsoletas, sem efeito prático

(vi) Urgência da matéria;

(vii) Atos normativos que não permitam adoção de solução regulatória diversa, em razão de exigência legal.

AIR Nível I AIR deve atender o princípio da proporcionalidade e ser realizado de acordo com a complexidade do tema a ser estudado:

A AIR nível I deve seguir os seguintes parâmetros: 


\begin{tabular}{|c|c|}
\hline & $\begin{array}{l}\text { (i) sumário executivo; } \\
\text { (ii) identificação do problema regulatório } \\
\text { (iii) que se pretende solucionar; } \\
\text { (iv) () identificação dos atores ou grupos afetados pelo problema } \\
\text { regulatório identificado; } \\
\text { (v) identificação da base legal que ampara a ação da agência, órgão } \\
\text { ou entidade no tema tratado; } \\
\text { (vi) definição dos objetivos que se pretende alcançar; } \\
\text { (vii) descrição das possíveis alternativas para o enfrentamento do } \\
\text { problema regulatório identificado, considerando a opção de não ação, } \\
\text { além das soluções normativas, e, sempre que possível, opções não } \\
\text { normativas; } \\
\text { (viii) exposição dos possíveis impactos das alternativas identificadas; } \\
\text { (ix) comparação das alternativas consideradas, apontando, } \\
\text { justificadamente, a alternativa ou a combinação de alternativas que se } \\
\text { mostra mais adequada para alcançar os objetivos pretendidos; } \\
\text { (x) descrição da estratégia para implementação da alternativa } \\
\text { sugerida, incluindo formas de monitoramento e de fiscalização, bem } \\
\text { como a necessidade de alteração ou de revogação de normas em vigor; } \\
\text { (xi) considerações referentes às informações, contribuições e } \\
\text { manifestações recebidas ao longo da elaboração da AIR em eventuais } \\
\text { processos de participação social ou outros processos de recebimento de } \\
\text { subsídios de interessados no tema sob análise; e } \\
\text { (xii) nome completo, cargo ou função e assinatura dos responsáveis } \\
\text { pela AIR. }\end{array}$ \\
\hline \multirow[t]{2}{*}{ AIR Nível II } & $\begin{array}{l}\text { Quando a análise realizada por meio da AIR de Nível I se mostrar } \\
\text { insuficiente para avaliação do problema, devem ser adicionadas as } \\
\text { seguintes análises: }\end{array}$ \\
\hline & $\begin{array}{l}\text { (i) levantamento da experiência internacional no tratamento do } \\
\text { problema regulatório; } \\
\text { (ii) mensuração dos possíveis impactos das alternativas de ação } \\
\text { identificadas sobre os consumidores ou usuários dos serviços prestados } \\
\text { e sobre os demais principais segmentos da sociedade afetados; e } \\
\text { (iii) abordagem do risco na AIR. }\end{array}$ \\
\hline Linguagem & Clara e simples \\
\hline Fontes de dados & Utilização de dados confiáveis que possam sempre ser verificados \\
\hline $\begin{array}{l}\text { Participação } \\
\text { popular }\end{array}$ & Redução de assimetria de informação e legitimação da decisão. \\
\hline
\end{tabular}

Fonte: Adaptado de CASA CIVIL (2018).

Posteriormente a publicação do mencionado Guia, em 2019, foi publicada a Lei das Agências Reguladoras - Lei 13.848 - a qual dispõe sobre a gestão, organização, processo decisório e controle social das agências reguladoras. 
Referida Lei, além de estabelecer requisitos para a governança das Agências, determinou que o processo de tomada de decisão no âmbito dessas Agências seja precedido de AIR quando tratar sobre intervenção que resulte na alteração de atos normativos de interesse geral dos agentes econômicos, consumidores ou usuários de serviços. Veja-se, nesse sentido, o $\operatorname{artigo} 6^{\circ}$ da referida norma

Art. $6^{\circ} \mathrm{A}$ adoção e as propostas de alteração de atos normativos de interesse geral dos agentes econômicos, consumidores ou usuários dos serviços prestados serão, nos termos de regulamento, precedidas da realização de Análise de Impacto Regulatório (AIR), que conterá informações e dados sobre os possíveis efeitos do ato normativo.

No mesmo contexto, em setembro de 2019 foi publicada Lei 13.874, que institui a Declaração dos Direitos de Liberdade Econômica.

Referida Lei, cujo objetivo foi o de estabelecer um marco legal para proteção da livre iniciativa e exercício da atividade econômica, previu a obrigatoriedade de realização da AIR quando da "proposta de edição de atos normativos de interesse geral dos agentes econômicos."

Art. $5^{\circ}$ As propostas de edição e de alteração de atos normativos de interesse geral de agentes econômicos ou de usuários dos serviços prestados, editadas por órgão ou entidade da administração pública federal, incluídas as autarquias e as fundações públicas, serão precedidas da realização de análise de impacto regulatório, que conterá informações e dados sobre os possíveis efeitos do ato normativo para verificar a razoabilidade do seu impacto econômico.

Importante notar, nesse contexto, que referida Lei, diferentemente na Lei 13.878 , determinou a aplicação da AIR para toda a administração pública que pretenda alterar atos normativos.

Em que pese as referidas leis tenham sido claras quanto à necessidade de aplicação da AIR na tomada de decisão relacionada a mudanças que afetem direitos econômicos, o tema ainda estava pendente de regulamento.

Assim, diante da necessidade de se especificar a aplicação da AIR, foi publicado o Decreto 10.411/2020 o qual regulamenta a aplicação da ferramenta em âmbito federal.

Referido decreto, estabelece as seguintes diretrizes para a aplicação da AIR: 


\section{Tema}

Abrangência

Obrigatoriedade

Objetivo

Inaplicabilidade

Dispensa

Transparência

Conteúdo da AIR

Método

\section{Diretrizes}

Órgãos e entidades da administração pública federal, direta, autárquica e fundacional

Alteração, edição ou revogação de atos normativos de interesse geral de agentes econômicos ou de usuários de serviços prestados.

Auxiliar na tomada de decisão

(i) Atos normativos de natureza administrativa;

(ii) Efeitos concretos destinados a situações específicas;

(iii) Disponham sobre execução orçamentária e financeira;

(iv) Disponham sobre política cambial e monetária;

(v) Disponham sobre segurança nacional;

(vi) Consolidem normas sem alteração de mérito.

Desde que fundamentado:

(i) Urgência

(ii) Ato normativo que discipline normativos superiores;

(iii) Ato normativo considerado de baixo impacto;

(iv) Atualização ou revogação de normas sem alteração de conteúdo;

(v) Preservação da liquidez, solvência ou higidez dos mercados:

(i) de seguro; (ii) financeiro; (iii) sistema de pagamentos;

(vi) Manutenção da convergência de padrões internacionais;

(vii) Ato que reduza as exigências, obrigações, restrições, requerimentos ou especificações com o objetivo de diminuir os custos regulatórios;

(i) Ato que revise normas desatualizadas tecnologicamente.

(ii) Notas Técnicas, relatórios e documentos relacionados a dispensa da realização da AIR devem ser públicas e acessíveis

(iii) Sumário executivo em linguagem simples e acessível;

(iv) Identificação do problema regulatório que se pretende regular;

(v) Identificação dos agentes afetados;

(vi) Identificação da fundamentação legal;

(vii) Definição dos objetivos;

(viii) Possíveis alternativas para o problema apresentado;

(ix) Exposição dos possíveis impactos;

(x) Considerações relevantes;

(xi) Experiência Internacional;

(xii) Comparação das alternativas;

(xiii) Descrição da estratégia sugerida.

(i) Análise multicritério; (ii) Análise custo-benefício; (iii) Análise custo-efetividade; (iv) Análise de custo; (v) Análise de risco; (vi) Análise de risco-risco

Escolha do método de análise deve ser justificado. 


\section{Tema}

Participação social

Avaliação

Resultado Regulatório

Força não vinculante

\section{Diretrizes}

Opção de realização de consulta pública.

No caso das Agências Reguladoras, a consulta pública é obrigatória

de Órgãos deverão implantar agenda de ARR

A avaliação posterior da medida escolhida para enfrentamento do problema regulatório é obrigatório em casos de dispensa de AIR.

A AIR não tem força vinculante.

O descumprimento dos parâmetros constantes no decreto não macula a norma editada e não a torna inválida

Fonte: Decreto 10.411/2020

Como se pode observar, a evolução da ferramenta de tomada de decisão tomou corpo no cenário brasileiro, sendo que, o que já vinha sendo observado no campo das Agências Reguladoras, com a aplicação de uma regulação mais transparente e responsiva, foi positivado por meio legal, passando ao campo da obrigatoriedade e não mais da faculdade.

Assim, embora ainda recente, a AIR vem se manifestando como uma realidade na regulação federal do Brasil.

\subsubsection{A AIR na ANEEL}

O processo de implementação da Resolução Normativa $n^{\circ}$ 540/2013 iniciou-se pela abertura da Audiência Pública nº 64/2012, a qual recebeu 78 contribuições relacionadas ao texto do normativo.

Da audiência pública participaram 20 instituições e empresas, as quais fizeram contribuições principalmente relacionadas a necessidade de fortalecimento da participação pública no âmbito da AIR.

A norma previu a utilização da ferramenta para todos os casos de expedição de atos normativos, a qual deve conter, no mínimo:

(i) identificação do problema;

(ii) justificativa para a intervenção regulatória;

(iii) o que se objetiva com a intervenção regulatória; 
(iv) prazo para implantação da intervenção pretendida;

(v) impactos das ações pretendidas;

(vi) eventuais alterações normativas;

(vii) identificação e previsão de acompanhamento das alterações pretendidas.

Para além da necessidade de observância desses requisitos mínimos, a Resolução Normativa também determinava a utilização da análise custo benefício. Por fim, estabelecia que o relatório final de AIR deveria ser disponibilizado em consulta/audiência pública, em conjunto com a minuta de resolução da opção escolhida pelo regulador.

Além desses requisitos, a Resolução Normativa previu em seu anexo, um formulário que deveria ser seguido pelos servidores para que a AIR fosse devidamente padronizado.

Nesse contexto, a aplicação da AIR no âmbito da ANEEL poderia ser sintetizada da seguinte forma:

(i) Identificação do problema regulatório

(ii) Elaboração da AIR

(iii) Escolha da melhor alternativa regulatória

(iv) Audiência/Consulta Pública relacionada a alternativa regulatória definida

(v) Análise das contribuições em Audiência/Consulta Pública

(vi) Decisão

Assim, em que pese a publicação da Resolução Normativa no 540/2013 tenha se demonstrado como um avanço no que se refere a responsabilização e governança na definição da regulação, na prática, a aplicação da AIR por meio do formulário publicado como anexo da Resolução Normativa $n^{\circ}$ 540/2013, não prestigiava a efetiva discussão das alternativas regulatórias elencadas, restringindo-se a colocar em discussão apenas a alternativa escolhida.

Passados 4 (quatro) anos da publicação normativa, a ANEEL propôs processo de simplificação e efetividade da norma, implementando nova Resolução Normativa - a Resolução Normativa n $^{\text {7 } 798, ~ a ~ q u a l ~ f o i ~ p u b l i c a d a ~ e m ~ d e z e m b r o ~ d e ~} 2017$. 
A revisão da norma foi motivada não apenas em razão de determinação normativa, visto que a própria Resolução Normativa ${ }^{\circ} 540 / 2013$ previa a sua reavaliação dentro de três anos, como também pela necessidade da própria Agência que, ao acompanhar o desenvolvimento da aplicação da regulação, observou pontos que poderiam ser aprimorados de modo a determinar uma norma mais efetiva para fins de aplicação na tomada de decisão.

Nesse contexto, e conforme nos relata a Nota Técnica 009/2017-ASD/ANEEL de 30/06/2017, foram observados que:

(...) 51 atos normativos foram emitidos sem a realização de AIR. Destes, 16 casos apresentaram alguma justificativa para dispensa da AIR e 35 atos normativos foram expedidos sem AIR e sem justificativa para sua dispensa. Ainda, dos 51 atos normativos em que não constaram AIR, 43 foram analisados pelo CT-AIR quanto a seu conteúdo, sendo registrado 28 casos nos quais a Nota Técnica trazia análise e fundamentos que poderiam constar de uma AIR

Ademais disso, a equipe responsável pela avaliação também identificou que:

(i) Atos normativos foram implementados sem a realização da AIR e sem qualquer justificativa para tanto

(ii) Algumas notas técnicas que fizeram parte dos normativos estudados continham dados e estudos que poderiam fazer parte de uma AIR;

(iii) Algumas AIR realizadas sequer continham detalhamentos os estudos realizados

(iv) Algumas normas foram implementadas sem AIR uma vez que se prestaram apenas a correção de erros formais ou cumprimento de norma superior

(v) Descumprimento de alguns pontos da norma, sendo o mais relevante a não definição de um prazo para realização da solução dada ao problema regulatório.

Diante desse contexto, a ANEEL identificou a necessidade de realizar ajustes na Resolução Normativa $n^{\circ}$ 540/2017 para que a AIR realizada na Agência fosse efetiva e se prestasse ao seu real propósito: o auxílio na tomada de decisão.

Assim, foi aberta a Audiência pública no 44/2017, a qual recebeu 105 (cento e cinco) contribuições de 23 (vinte e três) agentes distintos e exultou na revogação da Resolução Normativa nº 540/2017 com a publicação da Resolução Normativa nº 798/2017. 
Com relação à resolução anterior, a Resolução Normativa n 798/2017, trouxe alguns avanços relacionados a implantação da AIR na Agência, se assemelhando mais ao modelo de AIR proposto pela Casa Civil. Atualmente, cada AIR realização no Âmbito da ANEEL deve conter, no mínimo: a) sumário executivo em linguagem simples e acessível; (ii) identificação do problema regulatório; (iii) identificação dos afetados pelo problema regulatório; (iv) base legal; (v) possíveis alternativas para o problema encontrado; (vi) possíveis impactos das alternativas identificadas; (vii) comparação das alternativas propostas; (viii) formas de acompanhamento do novo ato a ser implantado, se implantado; (ix) contribuições dos agentes; (x) prazo para início de vigência.

Para além de aprimorar os requisitos mínimos da análise, a Resolução Normativa $\mathrm{n}^{\circ}$ 798/2017, também definiu:

Tabela 5 - Resolução Normativa no 798/2017

\section{Tema}

Abrangência

Caso o problema regulatório a ser analisado se demonstre complexo, a AIR a ser realizada deverá conter

mapeamento da experiência nacional e internacional no tratamento do problema regulatório sob análise;

mensuração, sempre que possível quantitativa, dos possíveis impactos das alternativas de ação identificadas sobre os consumidores ou usuários dos serviços prestados e sobre os demais principais segmentos da sociedade afetados;

mapeamento dos riscos envolvidos em cada uma das alternativas consideradas

Participação

pública

Tomada decisão nível I

Reforço participação pública

Tomada decisão nível II

Dispensa
A AIR será submetida a processo de consulta ou audiência pública antes mesmo da definição da escolha regulatória

de O relatório da AIR, após a audiência/consulta pública será submetido à decisão da diretoria para escolha da alternativa regulatória

da Minuta de ato normativo relacionado a escolha da alternativa regulatória é colocada novamente em audiência pública

de Após a análise das contribuições da segunda audiência pública há decisão sobre o assunto

(i) Atos de natureza administrativa

(ii) Correção de erro material

(iii) Consolidar atos normativos desde que não haja alteração de mérito 
Adequação de textos e referências, desde que não haja alteração de mérito

Avaliação de As normas, exceto nos casos de dispensa, devem prever prazo para Resultado reavaliação da medida implementada

Regulatório

Fonte: Resolução Normativa no 798/2017.

Note-se que a implementação da AIR, com a nova norma, adere mais ao objetivo para o qual foi criada, deixando, aparentemente, de ser um processo burocrático de mero preenchimento de informações e impondo análises e comparações factíveis.

Ponto importante também é o acompanhamento da norma regulatória por meio da Avaliação de resultado regulatório, que pretende acompanhar se os efeitos do ato foram alcançados e efetivados ao longo do tempo.

Em que pese a maior robustez dos requisitos e pressupostos a AIR, ainda não há avaliação sobre a sua efetividade.

2.4.1.1. Outros mecanismos de qualidade regulatória - envolvimento da sociedade e necessária participação pública: A Consulta Pública na ANEEL

Como mencionado no tópico anterior, a AIR envolve procedimento cujo principal objetivo é o de antever possíveis efeitos adversos da implementação de uma regulação. Podese antever, por exemplo, se a implantação de determinada norma refletirá negativamente no desenvolvimento da atividade regulada.

Não existe apenas uma maneira de realizar a Análise de Impacto Regulatório, no caso brasileiro, por exemplo, não existe consenso em como deve ser realizada a análise custo $\mathrm{x}$ benefício de uma determinada norma, tanto é assim que existem diversa formas reconhecidas de se fazer análise econômica de uma AIR. Em que pede haver divergência entre as opções para se implantar a avaliação de impacto regulatório, um ponto sobre o tema revela-se como consenso: a avaliação de impacto regulatório exige a participação do público a ser afetado pela regulação que se pretende implementar. 
Assim, como parte do processo, a participação pública é instrumento fundamental que permite coletar informações diversas do mercado, as quais, por vezes, a própria agência reguladora não obteve acesso prévio.

Nesse contexto, para além da necessidade de uma AIR com rigor metodológico (de acordo com a opção regulatória pretendida), deve ser dada especial atenção para a efetividade da participação pública no processo.

Veja-se que para que a AIR seja de fato efetiva, a participação pública também não pode apenas ser encarada como apenas mais uma etapa do processo, mas sim como fase essencial desse processo. Em outras palavras, a participação pública legitima o ato da Agência, confirmando ou mostrando soluções alternativas ao tema.

Para o caso específico da ANEEL, a participação pública efetiva se dá por meio das institucionalizadas Audiências ou Consultas Públicas, sendo essas previstas em sua lei de criação (Lei 9.427/1997) ${ }^{10}$ :

Assim, quando da quando a implementação de um ato normativo pela ANEEL esse deve ser necessariamente submetido a um processo de consulta pública. Desse modo, pontuam Bermann e Tarelho (2021, p. 160) que "o instituto da Audiência Pública é instrumento sedimentado e de larga utilização no âmbito da Agência sendo requisito de validade que seus atos normativos."

Dessa forma, em sendo um dever da Agência a realização dos processos de participação popular, sem a efetiva abertura da audiência ou consulta pública para a implantação de uma norma na Agência, tal ato resta maculado e acometido por ilegalidade irremediável, sendo verdadeiro requisito não apenas de legitimidade, mas também de legalidade do ato.

10 Art. 4ํ A ANEEL será dirigida por um Diretor-Geral e quatro Diretores, em regime de colegiado, cujas funções serão estabelecidas no ato administrativo que aprovar a estrutura organizacional da autarquia.

(...)

§ 3 o O processo decisório que implicar afetação de direitos dos agentes econômicos do setor elétrico ou dos consumidores, mediante iniciativa de projeto de lei ou, quando possível, por via administrativa, será precedido de audiência pública convocada pela ANEEL. (sem grifo no original) 
Mas, na ANEEL, utilização do instituto da consulta ou audiência pública também foi alargada com a previsão constante na Resolução Normativa nº 798/2017.

É que referida Resolução sedimentou ainda mais a importância que a ANEEL tem dado ao instituto, prevendo mais uma etapa de participação popular no processo de tomada de decisão. Isso porque, como já mencionado, a partir da publicação da referida Resolução o próprio AIR deve ser submetido a consulta ou audiência pública apartada, com a exclusiva função de discutir as alternativas ali propostas.

Dessa forma, um processo que já era intrínseco a atividade regulatória da ANEEL, ganhou mais um capítulo, o que ressaltou ainda mais a sua importância dentro do processo decisório da Agência.

Diante desse cenário, observa-se que o processo de participação pública é intrínseco e evidentemente necessário a devida AIR, sendo, inclusive, pressuposto valorizado na Resolução Normativa $\mathrm{n}^{\circ} 798 / 2017$.

\subsection{CONCLUSÃO PARCIAL}

A AIR pode ser entendida como uma ferramenta sistemática que permite, a partir da identificação de um problema regulatório, a avaliação de alternativas viáveis para tratamento do problema identificado por meio da análise de dados concretos que permitam analisar custos e benefícios da implantação da nova medida.

Surgida nos Estados Unidos, a ferramenta foi adotada como modelo de governança pela OECD, sendo posteriormente utilizada também no âmbito de regulação das relações entre os países da União Europeia.

No Brasil, iniciou sua popularização por meio por meio de do PRO_REG, tendo sido implantada na ANEEL em meados de 2013. A partir de 2019 a ferramenta vem sendo difundida e já é de uso obrigatório nas Agências Reguladoras. 
A ANEEL, desde sua primeira implantação, vem aprimorando a utilização da ferramenta, tendo essa se estabelecido como uma importante etapa do processo de tomada de decisão regulatória. 


\section{ESTUDO DE CASO: DEMAIS INSTALAÇÕES DE TRANSMISSÃO - DIT}

A presente seção apresenta estudo relacionado as DIT e a AIR realizada no caso de transferência dessas instalações determinado pela Resolução Normativa nº 798/2017.

\subsection{DESENHO INSTITUCIONAL DO SETOR DE TRANSMISSÃO DE ENERGIA ELÉTRICA BRASILEIRO}

A configuração do sistema elétrico brasileiro como atualmente conhecida - setores bem delineados, com funções típicas, segregadas e bem estabelecidas com a presença de entidades de comanda e controle - veio sendo desenvolvida no Brasil ao longo do tempo.

No entanto, para que se entenda a estrutura existente que acabou por resultar no conflito relacionado a transferência das DIT, há que se entender como foi formada a indústria elétrica no Brasil.

Nesse contexto, Ugeda Sanches (2011), analisando a legislação brasileira ao longo dos anos, enfatiza a energia como interesse local no período de 1900 a 1934. Isso significa que, a cadeia de produção de energia até a sua entrega ao consumidor final não era detida pela União e sim por estados ou munícipios, com legislação e exploração própria e distinta.

No mesmo contexto, Bermann, (1991) destaca que no período houve grande hegemonia de duas grandes empresas estrangeiras que controlavam toda a cadeira produtiva: LIGHT e AMFORP.

Já em 1934, com a promulgação de nova Constituição Federal ${ }^{11}$, foi definido como atribuição da União Federal legislar sobre matéria hidrelétrica. Surgiam aí os primeiros sinais da federalização da matéria elétrica no Brasil.

\footnotetext{
${ }^{11}$ Art 5 $5^{\circ}$ : Compete privativamente a União:

XIX - legislar sobre:

j) bens de domínio federal, riquezas do subsolo, mineração, metalurgia, águas, energia hidrelétrica, florestas, caça, pesca e sua exploração.
} 
No mesmo ano, foi publicado o Decreto 24.643. O intitulado Código de Águas, além de manter o controle de concessão e fiscalização de potenciais hidrelétricos com a União, previa regras federais para a utilização de potenciais hidrelétricos e exploração da atividade elétrica no Brasil.

No âmbito da transmissão de energia elétrica, no qual a presente investigação é focada, o Decreto estabeleceu importantes marcos que possibilitaram o desenvolvimento do setor. Assim, o artigo 151 do referido Código ${ }^{12}$ prévia a possibilidade de estabelecimento de linhas de transmissão e distribuição por empresas que explorassem potenciais hidrelétricos.

Ou seja, muito embora a atividade de produção, transmissão e distribuição de energia elétrica ainda fossem centralizadas em uma única empresa, a legislação já passava a prever expressamente o desenvolvimento da transmissão.Com a Constituição Federal de $1946^{13}$, não apenas a questão da hidreletricidade foi definida como competência legislativa da União, mas sim, toda a cadeia de produção, transmissão e distribuição de energia elétrica. Na mesma época, foram constituídas as grandes empresas de energia elétrica estatais, concentrando grande investimento público no desenvolvimento da indústria elétrica no Brasil.

Marco importante no desenvolvimento da indústria no Brasil é o desenvolvimento e constituição da ELETROBRAS, empresa que, além de consolidar a participação do Estado no âmbito elétrico, também assumia funções de planejamento e controle da cadeia produtiva de energia elétrica.

Há que se ressaltar que até então, toda a cadeia de produção, transmissão e distribuição era centralizada em uma só empresa. Ou seja, toda a atividade necessária para produção e distribuição de energia elétrica era desenvolvida por uma única companhia.

\footnotetext{
12 art. 151. Para executar os trabalhos definidos no contrato, bem como, para explorar a concessão, o concessionário terá, além das regalias e favores constantes das leis fiscais e especiais, os seguintes direitos (...) 
No entanto, em meados dos anos 50, a descentralização das atividades começou a ser desenhada. Em outras palavras, legalmente, começou a ser estabelecida a separação da cadeia produtivo. Assim, em 1957 foi publicado Decreto em que contou a primeira definição da atividade de transmissão.

Nesse contexto, o Decreto 41.019, definiu que:

\begin{abstract}
Art $4^{\circ}$. O serviço de transmissão de energia elétrica consiste no transporte desta energia do sistema produtor às subestações distribuidoras, ou na interligação de dois ou mais sistemas geradores.

$\S 1^{\circ}$. A transmissão de energia compreende também o transporte pelas linhas de subtransmissão ou de transmissão secundária que existirem entre as subestações de distribuição.

$\S 2^{\circ}$. O serviço de transmissão pode ainda compreender o fornecimento de energia a consumidores em alta tensão, mediante suprimentos diretos das linhas de transmissão e subtransmissão.
\end{abstract}

Em 1960 foi criado o Ministério de Minas e Energia, com a função de estabelecer políticas para desenvolvimento do setor elétrico no Brasil. Já em 1990, após a promulgação da Constituição Cidadã de 1988, a qual contava com diretrizes claras sobre a possibilidade de concessão, permissão ou autorização de serviços e atividades de interesse público, foi publicado o plano nacional de desestatização, por meio da Lei 8.031, a qual previa a transferência para iniciativa privada da exploração de certas atividades econômicas o que, segundo a mencionada Lei, permitiria com o Estado se centrasse em atividades que não poderiam ser delegadas, como, por exemplo: fiscalização, comando, controle e planejamento.

Em 1995 foi finalmente promulgada a Lei 8.987 que permitiria o desenvolvimento de atividades sob o modelo de concessão, permissão ou autorização. No mesmo contexto, ainda em 1995 foi promulgada também a Lei $\mathrm{n}^{\circ}$ 9.074, específica e voltada ao modelo de concessões, permissões e autorizações no setor elétrico.

Referida Lei iniciou a consolidação do marco de desverticalização do setor e permitiu a adaptação e regulação das concessões até então existentes, determinando que empresas que prestassem o serviço de energia elétrica deveriam assinar contratos de concessão específicos para tanto. 
A mencionada Lei era parte de um pacote de medidas que visava reestruturar o setor elétrico. Segundo Ugeda Sanches (2011), o chamado RESEB, visava, em especial:

(i) Adequar o sistema em razão de um possível esgotamento do modelo estatal, em especial para realização de novos investimentos

(ii) contenção de tarifas com fins políticos;

(iii) alto grau de ingerência política;

(iv) falta de capacidade para atração de capital privado.

O Projeto RESEB não culminou na publicação de uma lei determinada, mas em um conjunto de leis e decretos que estruturaram o setor e os órgãos de controle e regulação.

Diante disso iniciou-se o processo de privatização das empresas com a segregação das atividades de geração, transmissão e distribuição ${ }^{14}$.No âmbito da transmissão de energia elétrica, a Lei 9.074/1995 trouxe um importante avanço, visto que determinou a definição, dentre as instalações existentes, de quais instalações deveriam ser destinadas aos serviços de transmissão ${ }^{15}$ :

Art. $17 \mathrm{O}$ poder concedente deverá definir, dentre as instalações de transmissão, as que se destinam à formação da rede básica dos sistemas interligados, as de âmbito próprio do concessionário de distribuição, as de interesse exclusivo das centrais de geração e as destinadas a interligações internacionais.

Com a determinação de separação das atividades foi editado o Decreto $n^{\circ}$ 1.717/1995, o qual previu o envio pela ELETROBRAS ao DNAEE da relação de instalações pertencentes ao sistema de transmissão.

\footnotetext{
${ }^{14}$ Art. $4^{\circ}$ As concessões, permissões e autorizações de exploração de serviços e instalações de energia elétrica e de aproveitamento energético dos cursos de água serão contratadas, prorrogadas ou outorgadas nos termos desta e da Lei no 8.987, e das demais.

$\S 5^{\circ}$ As concessionárias, as permissionárias e as autorizadas de serviço público de distribuição de energia elétrica que atuem no Sistema Interligado Nacional - SIN não poderão desenvolver atividades:

I - de geração de energia elétrica

II - de transmissão de energia elétrica;

${ }^{15}$ A ANEEL define como Rede Básica: "Instalações de transmissão do Sistema Interligado Nacional - SIN, de propriedade de concessionárias de serviço público de transmissão, definida segundo critérios estabelecidos na regulamentação da ANEEL" (Disponível em: www.aneel.gov.br)
} 
Diante da obrigação legal, foi publicada a Portaria DNAEE $n^{\circ}$ 244/1996, a qual definiu que:

“Art. $1^{\circ}$ Definir que, para fins do disposto no $§ 5^{\circ}$ do art. 17 da Lei n ${ }^{\circ} 9.074 / 95$, as instalações de transmissão, existentes em operação na data de referência de 08 de julho de 1995, constantes dos anexos I e II desta portaria, passam a compor as redes básicas dos sistemas elétricos interligados Sul/Sudeste/Centro-Oeste e Norte/Nordeste".

Assim, a Portaria DNAEE tratou de listar as instalações existentes, classificando-as como instalações que comporiam a rede básica e, portanto, o serviço de transmissão.

Em 1998, com a publicação da Lei no 9.648 e se seu regulamento por meio do Decreto $\mathrm{n}^{\circ} 2.655$, no qual se estabeleceu no artigo $3^{\circ}$ que "II - o concessionário de transmissão contabilizará, em separado, as receitas, despesas e custos referentes às instalações de rede básica e os relativos às demais instalações de transmissão;" a ANEEL revisitou a classificação das instalações, publicando a Resolução 245/1998, na qual restou estabelecido como integrante da Rede Básica:

Art. $2^{\circ}$ A Rede Básica dos sistemas elétricos interligados será constituída por todas linhas de transmissão em tensões de $230 \mathrm{kV}$ ou superior e subestações que contenham equipamentos em tensão de $230 \mathrm{kV}$ ou superior, integrantes de concessões de serviços públicos de energia elétrica.

$\S 1^{\circ}$ Não serão consideradas integrantes à Rede Básica as linhas de transmissão e suas conexões, quando destinadas ao uso exclusivo de uma central geradora ou de um único consumidor.

$\S 2^{\circ}$ As instalações destinadas à conexão de linhas de transmissão e de distribuição, para atendimento de um concessionário de distribuição, não serão incluídas na Rede Básica, sendo tratadas como ativos de conexão.

$\S 3^{\circ}$ As instalações de transmissão de uso exclusivo de interligações internacionais não serão incluídas entre os ativos da Rede Básica.

Assim, foi estabelecido critério técnico para a definição dessas instalações, restando positivado que instalações iguais ou acima de $230 \mathrm{kV}$ de tensão comporiam a rede básica.

Mas a mesma Resolução também deu início ao conceito de demais instalações de transmissão, restando claro em seu artigo $3^{\circ}$ que instalações com tensão inferior a $230 \mathrm{kV}$ poderiam compor as instalações de transmissão. 
Posteriormente, em 2000, foi publicada a Resolução 166, a qual atualizou a composição da Rede Básica, listando os ativos até então existentes. Com base nesta atualização, é que os contratos de concessão de transmissão foram finalmente assinados.

Ainda nos anos 2000, foi publicada a Resolução 433, que revogou a Resolução 245/1998, e definiu novos conceitos para o estabelecimento da Rede Básica. A Resolução ainda previu que a partir da primeira revisão tarifária das transmissoras, os ativos antes classificados como Rede Básica poderiam ser reclassificados, sendo que, eventualmente os que na reclassificação ficassem fora da Rede Básica, poderiam, a critério do concessionário, serem transferidos para distribuidora.

Assim, a Resolução 443 previu que:

Art. $3^{\circ}$ Integram a Rede Básica as linhas de transmissão, os barramentos, os transformadores de potência e os equipamentos com tensão igual ou superior a $230 \mathrm{kV}$, com exceção das seguintes instalações e equipamentos:

I - instalações de transmissão, incluindo as linhas de transmissão, transformadores de potência e suas conexões, quando destinadas ao uso exclusivo de centrais geradoras ou de consumidores, em caráter individual ou compartilhado;

II - instalações de transmissão de interligações internacionais e suas conexões, autorizadas para fins de importação ou exportação de energia elétrica; e

III - transformadores de potência com tensão secundária inferior a $230 \mathrm{kV}$, inclusive a conexão.

Parágrafo único. As instalações e equipamentos de que tratam os incisos I, II e III deste artigo serão de responsabilidade do acessante. ou constava da Resolução 166/2000, seriam reclassificados.

Ocorre que, a simples publicação da Portaria do Ministério de Minas e Energia não supria a determinação constante na Lei 9.094/1995, na qual restou claro o comando de que, o poder concedente, deveria segregar as instalações definindo as que se destinam a formação da rede básica de transmissão. Tal comando não significou tão somente a segregação das instalações já existentes, mas sim a criação de um critério técnico para que essas instalações fossem de fato, segregadas.

Nesse contexto, em 2004, a ANEEL publicou a Resolução Normativa nº 67, na qual restou determinado o critério técnico para segregação das instalações: 
Art. $3^{\circ}$ Integram a Rede Básica do Sistema Interligado Nacional - SIN as Instalações de Transmissão, definidas conforme inciso II do artigo anterior, que atendam aos seguintes critérios:

I - linhas de transmissão, barramentos, transformadores de potência e equipamentos de subestação em tensão igual ou superior a $230 \mathrm{kV}$; e

II - transformadores de potência com tensão primária igual ou superior a 230

$\mathrm{kV}$ e tensões secundária e terciária inferiores a $230 \mathrm{kV}$, bem como as respectivas conexões e demais equipamentos ligados ao terciário, a partir de $1^{\circ}$ de julho de 2004 .

Posteriormente, em 2004, a Resolução 443 foi revogada pela Resolução Normativa 67/2004. Tal Resolução então, definiu como Rede Básica:

Art. $3^{\circ}$ Integram a Rede Básica do Sistema Interligado Nacional - SIN as Instalações de Transmissão, definidas conforme inciso II do artigo anterior, que atendam aos seguintes critérios:

I - linhas de transmissão, barramentos, transformadores de potência e equipamentos de subestação em tensão igual ou superior a $230 \mathrm{kV}$; e

II - transformadores de potência com tensão primária igual ou superior a 230 $\mathrm{kV}$ e tensões secundária e terciária inferiores a $230 \mathrm{kV}$, bem como as respectivas conexões e demais equipamentos ligados ao terciário, a partir de $1^{\circ}$ de julho de 2004.

Mas a Resolução Normativa n ${ }^{\circ}$ 67/2004 não apenas trouxe novos conceitos a formação da Rede Básica como positivou o conceito de DIT. A evolução dos conceitos aplicáveis ao setor de transmissão pode ser observada da tabela abaixo:

Tabela 6 - Evolução do conceito de Rede Básica

\begin{tabular}{|c|c|c|}
\hline Resolução & Conceito de Rede Básica & O que não é considerado Rede Básica \\
\hline $\begin{array}{l}\text { Resolução } \\
245 / 1998\end{array}$ & $\begin{array}{l}\text { Linhas de transmissão em } \\
\text { tensão de } 230 \mathrm{kV} \text { ou superior } \\
\text { e subestações que contenham } \\
\text { equipamentos em tensão de } \\
230 \mathrm{kV} \text { ou superior, } \\
\text { integrantes de concessões. }\end{array}$ & $\begin{array}{l}\text { - Linhas de Transmissão e suas } \\
\text { conexões de uso exclusivo de uma central } \\
\text { geradora } \\
\text { - Instalações de Conexão de linhas de } \\
\text { transmissão e distribuição para } \\
\text { atendimento de um concessionário de } \\
\text { distribuição } \\
\text { - Instalações de transmissão de uso } \\
\text { exclusivo de interligações internacionais }\end{array}$ \\
\hline $\begin{array}{l}\text { Resolução } \\
433 / 2000\end{array}$ & $\begin{array}{l}\text { Barramentos, } \\
\text { transformadores de potência e } \\
\text { os equipamentos com tensão } \\
\text { igual ou superior a } 230 \mathrm{kV} \text {, com } \\
\text { exceção das seguintes } \\
\text { instalações e equipamentos: }\end{array}$ & $\begin{array}{l}\text { - Instalações de transmissão, incluindo } \\
\text { as linhas de transmissão, transformadores } \\
\text { de potência e suas conexões, quando } \\
\text { destinadas ao uso exclusivo de centrais } \\
\text { geradoras } \\
\text { - Instalações de transmissão de } \\
\text { interligações internacionais }\end{array}$ \\
\hline
\end{tabular}




\begin{tabular}{|c|c|c|}
\hline Resolução & Conceito de Rede Básica & $\begin{array}{l}\text { O que não é considerado Rede Básica } \\
\text { - Transformadores de potência com } \\
\text { tensão secundária inferior a } 230 \mathrm{kV} \text {, } \\
\text { inclusive a conexão }\end{array}$ \\
\hline $\begin{array}{l}\text { Resolução } \\
67 / 2004\end{array}$ & $\begin{array}{l}\text { - linhas de transmissão, } \\
\text { barramentos, } \\
\text { transformadores de potência } \\
\text { e equipamentos de } \\
\text { subestação em tensão igual } \\
\text { ou superior a } 230 \mathrm{kV} \text {; } \\
\text { - transformadores de potência } \\
\text { com tensão primária igual ou } \\
\text { superior a } 230 \mathrm{kV} \text { e tensões } \\
\text { secundária e terciária } \\
\text { inferiores a } 230 \mathrm{kV},\end{array}$ & $\begin{array}{l}\text { - instalações e equipamentos } \\
\text { associados, em qualquer tensão, quando de } \\
\text { uso exclusivo para importação e/ou } \\
\text { exportação de energia elétrica e não } \\
\text { definidos como instalações de transmissão } \\
\text { de energia elétrica destinadas a interligações } \\
\text { internacionais } \\
\text { linhas de transmissão, barramentos, } \\
\text { transformadores de potência e equipamentos } \\
\text { de subestação, em tensão inferior a } 230 \mathrm{kV} \text {, } \\
\text { localizados ou não em subestações } \\
\text { integrantes da Rede Básica. }\end{array}$ \\
\hline
\end{tabular}

Fonte: Resolução 245/1998. Resolução 433/2000. Resolução 67/2004.

\subsubsection{O setor de transmissão e as DIT}

Como narrado, o conceito do que de fato comporia os sistemas de transmissão de energia foi delineado a partir da publicação da Lei 9.074/1995, tendo sido definitivamente detalhado apenas em 2004, com a publicação da Resolução Normativa nº 67/2004 pela ANEEL.

Mas o fato é que a referida Resolução não apenas detalhou o que seriam as instalações de transmissão de energia elétrica, como também criou uma categoria adicional, a das Demais Instalações de Transmissão. É bem verdade que da análise do Decreto 2.655/1998, já se verifica a menção às Demais Instalações de Transmissão, no entanto, o fato é que, no âmbito normativo, essas só foram detalhadas com a resolução Normativa de 2004. 
Assim, o artigo $4^{\circ}$ da Resolução Normativa $n^{\circ}$ 67/2004 criou uma nova categoria de instalações - as DIT, a qual estaria fora da classificação da Rede Básica mas que, ainda assim, poderia ser operada por empresas de transmissão de energia elétrica

Art. $4^{\circ}$ Não integram a Rede Básica e são classificadas como Demais Instalações de Transmissão, as Instalações de Transmissão que atendam aos seguintes critérios:

I - linhas de transmissão, barramentos, transformadores de potência e equipamentos de subestação, em qualquer tensão, quando de uso de centrais geradoras, em caráter exclusivo ou compartilhado, ou de consumidores livres, em caráter exclusivo;

II - instalações e equipamentos associados, em qualquer tensão, quando de uso exclusivo para importação e/ou exportação de energia elétrica e não definidos como instalações de transmissão de energia elétrica destinadas a interligações internacionais; e (Redação dada pela REN ANEEL 442, de 02.07.2011)

III - linhas de transmissão, barramentos, transformadores de potência e equipamentos de subestação, em tensão inferior a $230 \mathrm{kV}$, localizados ou não em subestações integrantes da Rede Básica

Nesse contexto, as DIT seriam instalações que não se enquadrariam no conceito de Rede Básica, mas que ainda assim exerceriam alguma função relacionada a esse serviço.São em geral, por sua característica técnica, instalações que se prestam a conexão de sistemas e permitem a conexão de consumidores ou distribuidores a rede de transmissão de energia elétrica. Para fins da presente investigação, utilizaremos essencialmente o conceito de DIT trazido pela aludida Resolução.

Mas em que pese a definição de DIT tenha restado clara na resolução Normativa $\mathrm{n}^{\circ}$ 67/2004, ainda restava definir a responsabilidade pela execução de obras e reforços nessas instalações. A própria Resolução Normativa nº 67/2004, assim como a Resolução Normativa $n^{\text {o }}$ 68/2004 determinaram que investimentos necessários nessas estruturas deveriam ser realizados pelas transmissoras que detinham tais concessões. A esse respeito, é esclarecedora manifestação da ANEEL na Nota Técnica n ${ }^{\circ}$ 0032/2015-SRD/ANEEL, de 02/06/2015 que abriu a Audiência Pública $n^{\circ} 41 / 2015$, a qual tratou da transferência das demais instalações de transmissão das transmissoras para as distribuidoras:

Posteriormente, a REN no 67/2004 finalmente deu tratamento específico às instalações de tensão inferior a $230 \mathrm{kV}$ de propriedade de transmissora, classificando-as como DIT. Já as regras de acesso nessas instalações foram estabelecidas na REN no 68/2004. Esta Resolução transferiu para as transmissoras a responsabilidade pelos reforços nas DIT. Desse modo, as REN 
$n^{\circ} 67$ e 68/2004 alteraram as responsabilidades sobre as DIT. Até então, a responsabilidade era das distribuidoras e, após, passou para as transmissoras.

Dessa forma, no sistema de transmissão brasileiro, transmissoras de energia elétrica operam tanto instalações da Rede Básica quanto DIT, sendo responsáveis, inclusive, pela realização de investimentos nesses equipamentos.

\subsection{O CONFLITO ENTRE TRANSMISSORAS E DISTRIBUIDORAS: A TRANSFERÊNCIA DAS DIT}

Como visto, quando da reorganização do sistema elétrico brasileiro, pós movimento de desverticalização do setor, definiu-se o que seriam as instalações que comporiam o sistema de transmissão de energia elétrica e quais as instalações comporiam o sistema de distribuição de energia elétrica.

Em razão de atribuição legal, restou como responsabilidade da ANEEL definir quais as instalações comporiam a Rede Básica e quais comporiam os sistemas de Distribuição. Finalmente, foi publicada a Resolução Normativa nº 67/2004 que colocou fim a questão.

Ocorre que, uma vez que quando da efetiva separação dos ativos para fins de segregação dos serviços de distribuição e transmissão e assinatura dos contratos de concessão, algumas instalações que atualmente não comporiam a Rede Básica acabaram ficando sob a concessão de transmissoras de energia.

Diante desse cenário, a ANEEL, em julho de 2015, entendeu pela necessidade de se estudar uma possível transferência desses ativos que não compunham a Rede Básica das transmissoras para as distribuidoras de energia elétrica. Nesse contexto, foi publicado o aviso da abertura da Audiência Pública no 41/2015, cujo objetivo principal foi o de "obter subsídios para a análise da proposta de transferência das Demais Instalações de Transmissão - DIT para as distribuidoras.".

O fundamento principal da abertura da referida Audiência Pública foi o de que as DIT, estabelecidas na Resolução Normativa $n^{\circ}$ 67/2004, desempenhariam funções típicas de 
distribuição de energia, havendo, portanto, necessidade de transferi-las às distribuidoras de energia elétrica.

Posta a questão em análise, instaurou-se com conflito dual, entre transmissoras e distribuidoras. Por um lado, as transmissoras não queriam ser compelidas a transferir suas instalações, uma vez que perderiam a receita associada a essas, de outro, as distribuidoras alinhavam-se com a possibilidade de transferência, visto a possibilidade de realizar investimentos nessas instalações receber remuneração para tanto ${ }^{16}$.

\subsubsection{A Audiência Pública $n^{\circ} 41 / 2015$}

A presente subseção apresenta uma análise relacionada a Audiência Pública que deu base a publicação da Resolução Normativa no 798/2017 que determinou a transferência das DIT

\subsubsection{Primeira fase da Audiência Pública n ${ }^{\circ}$ 41/2015}

Verificada pela ANEEL a existência de possível problema regulatório associado à operação, pelas transmissoras de energia elétrica de ativos de distribuição, essa iniciou processo de coleta de dados e estudos, prévio à Audiência Pública nº 41/2015.

Essa fase prévia à Audiência Pública nº 41/2015, além de constar em processo administrativo, foi enfaticamente narrada na abertura da referida Audiência Pública.

Assim, quando verificada a questão da possível operação de ativos de distribuição por empresas de transmissão, a SRD consultou a ABRADEE, bem como a Distribuidora CPFL Distribuição, a Elektro, além da CTEEP, sendo essas, na avaliação prévia realizada pela SRD, as empresas mais afetadas por possível regulação sobre o tema.

Em resumo, todas as empresas se manifestaram, sendo que as distribuidoras se posicionaram a favor de possível alteração da regulação vigente com a consequência transferência das DIT para as distribuidoras e a CTEEP se manifestou contrariamente por

\footnotetext{
${ }^{16}$ De acordo como quando consta no Procedimento de Regulação Tarifária da ANEEL, tanto distribuidoras quanto transmissoras de energia elétrica auferem receita: (i) pela operação e manutenção de seus ativos; (ii) pelos investimentos realizados em seus ativos,
} 
entender que eventual alteração no modelo de exploração dos ativos poderia lhe trazer grande impacto financeiro.

Realizado esse levantamento prévio, o qual consta de forma detalhada na Nota Técnica n ${ }^{\circ}$ 0032/2015-SRD/ANEEL de 02/06/2015 foi aberta a Audiência Pública no 41/2015 com o objetivo de "obter subsídios para a análise da proposta de transferência das Demais Instalações de Transmissão - DIT para as distribuidoras." O prazo para envio de contribuições dos interessados se iniciou em 29/06/2015 a 31/08/2015.

As justificativas para abertura da Audiência Pública, de acordo com a Nota Técnica ${ }^{\circ}$ 0032/2015-SRD/ANEEL, além da já explicitada possível operação de ativos de distribuição por concessionarias de transmissão, também se pautaram em:

(i) Obras realizadas em DIT, cuja operação atende especialmente a rede de distribuição, são mais morosas e custosas para os consumidores finais, visto que o processo de realização de obras por transmissoras depende de anuência/homologação do regulador

(ii) As DIT já estariam totalmente amortizadas e depreciadas, ou ainda que não estivessem, teriam eventuais indenizações pelo período não amortizado o não depreciado, nos termos da Lei 12.783/2013 que promoveu a renovação das concessões existentes ${ }^{17}$;

(iii) Uma vez que as instalações que se pretendia transferir estariam totalmente amortizadas e depreciadas, não haveria indenização vinculada, de modo que não haveria necessidade de investimento adicional das distribuidoras para o recebimento das DIT

\footnotetext{
${ }^{17}$ A renovação das concessões de transmissão por meio da Lei 12.783/2013 impôs novo modelo de prestação dos serviços de transmissão no âmbito brasileiro. Assim, em razão da determinação legal, todos os ativos ainda não amortizados ou depreciados seriam indenizados no momento da renovação e posteriormente, as empresas receberiam apenas por novos investimentos realizados e para operar e manter os ativos sob concessão. Ocorre que as indenizações devidas demoraram anos para serem calculadas, tendo sido estabelecidas as diretrizes para cálculo apenas em 2016, pela Portaria do Ministério de Minas e Energia no 120.

A renovação trouxe diminuição de fluxo de caixa dessas empresas, como destaca Silva, et al (2019):"The effects on the transmission companies, hereinafter referred to as Transmission System Operators (TSOs), were enormous: the total annual revenue of the major TSOs dropped by $60 \%$ in 2013. As a result, most of these companies faced cash flow problems in the following years. Moreover, the perceived risk increased, and investors lost interest in the transmission sector. It was not until 2016, after the government announced new guidelines, that this trend was reversed".
} 
Com tais argumentos como sendo os principais que motivariam a transferência das DIT das transmissoras para as distribuidoras, a SRD entendeu pela possibilidade de transferência das seguintes classes de DIT (ANEEL, 2015)

\begin{abstract}
Em resumo, as seguintes DIT seriam transferidas: • Subestações com tensão primária inferior a $230 \mathrm{kV}$ (SE DIT): todos os ativos na subestação seriam transferidos para distribuidora detentora da área de concessão onde se localiza a subestação, com exceção das entradas de linha referentes ao acesso de outras distribuidoras, que seriam transferidas para as respectivas acessantes. Subestações de Rede Básica de Fronteira (SE RBF): os ativos com tensão inferior a $230 \mathrm{kV}$ seriam transferidos para a distribuidora detentora da área de concessão onde se localiza a subestação, com exceção dos barramentos secundário e terciário do transformador de fronteira e das entradas de linha a ele conectadas (que não seriam transferidos), e das entradas de linha referentes ao acesso de outras distribuidoras conectadas aos demais barramentos (que seriam transferidas para as distribuidoras acessantes). - Linhas de distribuição: inteiramente transferidas para uma distribuidora, buscando manter o princípio de que o acessante detém os ativos à jusante do ponto de conexão. 76. As DIT em operação seriam transferidas de uma concessionária (de transmissão) para outra (de distribuição), de acordo com os procedimentos definidos na regulamentação econômica e financeira vigente.
\end{abstract}

Diante dessas diretrizes, foi sugerida minuta de Resolução Normativa que previu:

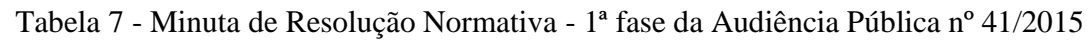

\begin{tabular}{|c|c|}
\hline Tema & Previsão na Resolução \\
\hline $\begin{array}{l}\text { DITs a } \quad \text { serem } \\
\text { transferidas }\end{array}$ & $\begin{array}{l}\text { DITS previamente listadas pela SRD, sendo divididas em } \\
\text { Subestações e Linhas }\end{array}$ \\
\hline Prazo & 3 anos \\
\hline Obras já previstas & Obras já previstas devem ser executadas pelas transmissoras \\
\hline Indenização & Para obras/instalações ainda não depreciadas \\
\hline & Instalações já depreciadas devem ser transferidas sem ônus \\
\hline
\end{tabular}

Fonte: $1^{\text {a }}$ fase da Audiência Pública n ${ }^{\circ} 41 / 2015$.

Aberta a Audiência Pública na 22ª Reunião Pública Ordinária de 2015, foram recebidas contribuições de 38 instituições e empresas distintas. Tais contribuições que vão da concordância total sobre a proposta de transferência, até a ilegalidade da proposta, podem ser assim sintetizadas: 
Tabela 8 - Resumo das contribuições à primeira fase da Audiência Pública nº 41/2015

ABRACE

ABRADEE

ABRATE

AES Brasil

Ampla Energia e Serviços
Período de transição para transferência das DIT deve ser melhor regulado, Sim com a definição do responsável por eventuais melhorias durante esse período.

Sugestão de redação para que seja explicitado que DIT de uso exclusivo de centrais geradoras e consumidores livres não serão transferidos.

Necessidade de prever tratamento extraordinários às distribuidoras que Sim incorram em altos custos com o recebimento das DIT.

Necessidade de prever laudo de avaliação dos ativos a serem transferidos antes da efetiva transferência.

Exclusão do prazo de 3 anos para transferência.

A transferência das DIT seria ilegal, visto que não há autorização do Poder Concedente.

A Transferência ocasionaria, necessariamente, o reequilíbrio econômico financeiro.

Pretende tornar a transferência voluntária e não compulsória.

Neutralidade dos impactos financeiros as distribuidoras.

Prazo para incorporação dos ativos de DIT deve ser previsto de acordo com as revisões tarifárias das distribuidoras.

Eventual indenização deve ser paga em parcelas mensais, entre as revisões tarifárias das distribuidoras. 


\section{Instituição}

CEB Distribuição S.A.

Companhia Estadual de Distribuição de Energia Elétrica (CEEE-D)

\section{CEEE GT}

\section{Celeo Redes Brasil}

\section{Resumo da contribuição}

Prazo para incorporação deve ser de 5 anos.

A incorporação das DIT pode afetar os índices de qualidade e continuidade das distribuidoras.

Custos adicionais de operação e manutenção devem ser considerados nos processos de revisão tarifária das DIT.

Alteração do prazo para recebimento dos ativos em transferência.

A transferência das DIT implicaria em custos adicionais para o sistema de Não transmissão (como, por exemplo, a duplicação de estruturas de proteção).

A necessidade de instalações com tensão inferior a $230 \mathrm{kV}$ foi reconhecimento nos relatórios do projeto RESEB.

A redução de funcionários em razão da transferência das DIT nem sempre se demonstra possível, o que não reduz os custos da transmissão.

A remuneração das transmissoras para realização dos investimentos é menor que das distribuidoras, o que poderia invalidar a premissa da ANEEL de que a transferência implicaria em menores custos para a sociedade.

Contribuições técnicas associadas aos equipamentos que devem ser Sim transferidos: banco de capacitores e transformadores de aterramento não devem ser transferidos.
Concorda com a

transferência das

DIT?

Sim 


\section{Instituição}

Celesc Distribuição S.A

CELG GT

CEMIG

COMPANHIA HIDROELÉTRICA SÃO PATRÍCIO

Coelce

\section{CHESF}

\section{Resumo da contribuição}

Necessidade de elaboração de laudo de avaliação previamente transferência das DIT.

Prazo para recebimento das DIT deveria ser alterado para até a segunda revisão tarifária após a publicação da Resolução.

Requer que a resolução seja adaptada as especificidades de sua rede.

$\operatorname{Sim}$

As transmissoras consideraram a operação das DIT quando da renovação Não das concessões, de modo que a transferência ocasionaria um desequilíbrio contratual.

Necessidade de duplicação das infraestruturas.

Contribuições relacionadas a necessidade de manutenção do equilíbrio Sim econômico financeiro dos contratos.

Contribuição relacionada a uma especificidade técnica da COMPANHIA Sim HIDROELÉTRICA SÃO PATRÍCIO que acessa a rede da CEG -D.

Sugestão para que o prazo de recebimento das DIT pelas distribuidoras seja Sim concatenado com as revisões tarifárias.

Sugestão de pagamento parcelado da indenização.

Cooperativa de Distribuição de. Energia Elétrica Fronteira Noroeste
Concorda com a

transferência das

DIT?

Sim

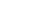




\section{Instituição}

COPEL

Coprel Cooperativa de Energia

CPFL Energia

CTEEP

DEMEI

\section{Resumo da contribuição}

Concorda com a

transferência das

DIT?

Copel ressalta que já transferiu seus ativos com tensão abaixo de $230 \mathrm{kV}$ Sim para e sugere a abertura de nova audiência pública para prever a transferência de outros ativos acessórios.

Apresenta que no caso específico da Coprel, a transferência de ativos Não resultara em aumento de custos para os consumidores atendidos pela cooperativa.

Durante os três primeiros anos de transferência, até a primeira revisão, a Sim RAP que seria percebida pela transmissora antes detentora da DIT deve ser incorporada na receita da distribuidora.

Transferência das DIT não foi respaldada por estudos técnicos e Não econômicos.

As DIT nem sempre exercem função de distribuição.

A transferência das DIT ocasionaria desequilíbrio econômico financeiro.

Diversas das DIT operadas pela CTEEP exercem função sistêmica de transmissão.

A ANEEL não tem competência para determinar a transferência das DIT.

Contribuições técnicas específicas sobre as instalações que deveriam ficar Sim sob a responsabilidade da empresa. 


\section{Instituição}

EDP Energias do Brasil

\section{ELEKTRO}

\section{ELETROSUL}

Federação das Cooperativas de Energia, Telefonia, Desenvolvimento Rural do Rio

Grande do Sul

FNE

\section{Resumo da contribuição}

Entende que deve prevalecer o interesse público, de forma que a transferência só deve ser realizada em casos que os custos para operação dos ativos pela distribuição seja inferior aos custos da transmissão.

A distribuidora deve apresentar, em até doze meses da publicação da resolução, um plano para incorporação das DIT.

Durante o período de incorporação até a primeira revisão, a RAP que seria percebida pela transmissora antes detentora da DIT deve ser incorporada na receita da distribuidora.

Custos incorridos entre a incorporação e a revisão tarifária devem ser Sim reconhecidos e ponderados para não gerar desequilíbrio nos contratos de concessão da transmissão.

ANEEL não teria competência para determinar a transferência. A Não competência da ANEEL estaria restrita a classificação das instalações.

\section{A transferência deveria se dar de forma voluntária.}

Sugestão de que permissionárias também possam receber as DIT em Sim transferência.

Nem todas as DIT exercem função de distribuição, sendo necessário Sim verificar sua função sistêmica.

DIT?

Sim

Concorda com a

transferência das 


\section{Instituição}

FURNAS

Grupo Energisa

Hidrelétrica Panambi S.A

Confederação Nacional das Cooperativas de Infra-estrutura

\section{LIGHT}

Neonergia S.A

\section{Resumo da contribuição}

Concorda com a

transferência

DIT?

Transferência deve ocorrer mediante acordo entre distribuidoras e Sim transmissoras de energia e não de forma compulsória.

DIT devem ser transferidas mediante critério técnico e não apenas baseado na tensão da instalação.

Deve ser realizada avaliação prévia dos ativos a serem transferidos.

Até a revisão da distribuidora, deve ser garantida a cobertura dos custos de operação e manutenção.

Nem toda DIT desempenha função de distribuição.

Instalações de uso compartilhado deveriam ser mantidas com as Sim transmissoras.

As DIT a serem transferidas devem passar por processo de inspeção antes

$\operatorname{Sim}$ da transferência.

Os custos de operação e manutenção das instalações transferidas devem ser reconhecidos até a próxima revisão tarifária.

Distribuidora deve apresentar em até 12 meses da publicação da resolução Sim um cronograma para incorporação das DIT.

Os custos de operação e manutenção das instalações transferidas devem ser reconhecidos até a próxima revisão tarifária. 


\section{Instituição}

Rima Industrial S.A

ONS

Secretaria do Estado de São Paulo

Sindicato dos Engenheiros no Estado de São Paulo

\section{Resumo da contribuição}

Concorda com a

transferência

DIT?

DIT de uso exclusivo de consumidores e centrais geradoras não devem ser transferidas.

Distribuidoras devem continuar requerendo a avaliação do ONS para Sim conexão de novos acessantes em DIT, assim como realizado atualmente pelas transmissoras.

Preocupação com a redução do quadro de funcionário da CTEEP, bem como Não com a composição do equilíbrio econômico financeiro do contrato.

DIT que exercem função sistêmica de distribuição não devem ser Não transferidas

A transferência compulsória seria alteração unilateral do contrato de concessão

A transferência de ativos poderia se caracterizar como desestatização de ativos para empresa federais, o que necessitaria de autorização legislativa

Federação dos Trabalhadores nas Solicita comprovação de que as distribuidoras possuem capacidade técnica Não Indústrias Urbanas do Estado de São e financeira para assunção das DIT.

Paulo

Transmissora Aliança de Energia Elétrica S.A

DIT são parte da composição do equilíbrio econômico financeiro dos Não contratos, de modo que não podem ser transferidas unilateralmente

Fonte: $1^{\text {a }}$ Fase da Audiência Pública n ${ }^{\circ} 41 / 2015$. 
Como observado, a grande maioria das contribuições foi favorável a transferência das DIT, no entanto, dentre as empresas e instituições que se mostraram a favor da proposta de transferência das DIT duas contribuições se destacaram:

(i) Necessidade de revisão do prazo para transferência;

(ii) Necessidade de revisão do estado dos ativos e reconhecimento do incremento de custos para operar e manter as instalações transferidas para as distribuidoras.

Dentre as empresas que não concordaram com a proposta de transferência dos ativos para as transmissoras, três contribuições também se destacam:

(i) Desequilíbrio econômico financeiro que pode ser ocasionado pela transferência das DIT;

(ii) Incompetência da ANEEL para determinar a transferência das DIT;

(iii) As DIT deveriam ser classificadas pela função que exercem no sistema de transmissão e distribuição de energia e não apenas pela tensão que operam.

Ademais das contribuições que mais se repetem nos documentos analisados, também se observa uma discussão sobre a possível inverdade da afirmativa de que todas as DIT exerceriam função de distribuição.

Pela análise das contribuições, se percebe de modo claro a confirmação de uma dualidade que se iniciava na abertura da audiência pública: de um lado as distribuidoras a favor da transferência, requerendo pequenos ajustes na regulação, em especial quanto ao prazo para o recebimento das DIT e reconhecimento tarifário; de outro as transmissoras que em sua grande maioria entendiam pela impossibilidade da transferência.

Em especial sobre as contribuições relacionadas a falta de competência da ANEEL para determinar a transferência das DIT, a procuradoria da Agência, inicialmente, havia sido consultada sobre o tema, opinando pela possibilidade da transferência por meio do Parecer 183/2014-PGE/ANEEL/PGF/AGU.

No entanto, em 2015, tal parecer foi modificado, oportunidade na qual a Procuradoria opinou pela impossibilidade de determinação de transferência das DIT, uma vez que 
determinação nesse sentido caberia tão somente ao Poder Concedente que, em termos relacionados a concessões de energia elétrica, é representado pelo Ministério de Minas e Energia.

O entendimento da SRD, no entanto, ia em sentido oposto, tendo sido firmado o entendimento de que a competência para determinar a transferência era de fato da Agência reguladora.

Firmado então o entendimento de que haveria competência da ANEEL para seguir com as discussões relacionadas a transferência das DIT, entendeu-se pela necessidade de abertura de uma segunda fase de discussões, com período para envio de contribuições de 28/04/2016 a 27/06/2016.

A segunda fase de discussões teve seu escopo reduzido, uma vez que entendeu a diretoria da ANEEL que a determinação ampla de instalações classificadas como DIT não se mostrava viável.

\subsubsection{A segunda fase da Audiência Pública nº 41/2015}

Após análise das contribuições recebidas no âmbito da primeira fase da Audiência Pública $n^{\circ}$ 41/2015 por meio da Nota Técnica SRD/SRT/SCT/SRM/SGT/SFF nº 48/2016 entendeu a diretoria da ANEEL, em sua Na 14a Reunião Pública Ordinária de 2016, pela abertura de uma segunda rodada de discussões. Essa segunda rodada centrou-se em alguns dos aspectos da transferência das DIT, que teve o seu escopo reduzido.

Da análise das contribuições apresentadas na primeira fase da Audiência Pública Nota Técnica no 48/2016, concluíram as superintendências responsáveis pela análise que de fato, algumas das preocupações demonstradas pelos agentes se mostraram verdadeiras e impediriam a transferência das DIT como sugerido na primeira fase da Audiência Pública.

a) Competência da ANEEL para determinar a transferência das DIT

Alguns dos agentes que contribuíram na primeira fase da Audiência Pública no sentido de que ANEEL não teria a competência necessária para determinar a transferência das DIT. 
Isso porque, haveria a necessidade de requerer uma chancela do Poder Concedente, em razão da determinação contida no artigo 17 , da Lei $n^{\circ}$ 9.074/95, artigo $6^{\circ}$, do Decreto ${ }^{\circ}$ 2.655/98 e art. $4^{\circ}$, do Decreto 2.335/97.

Inicialmente, por meio do Parecer 183/2014, a procuradoria da Agência entendeu pela existência de competência do órgão regulador para determinação da transferência. No entanto, em revisão de sua opinião inicial e por meio do Parecer 00786/2015/PFANEEL/PGF/AGU, a procuradoria entendeu pela incompetência legal da ANEEL para determinar a transferência, visto que pela legislação citada haveria a necessidade de chancela do Poder Concedente.

Em que pese a mudança de entendimento por parte da procuradora, na segunda fase da audiência pública as áreas técnicas entenderam pela competência da Agência, opinando pelo prosseguimento do tema na Agência.

b) Redução de escopo da segunda fase da Audiência Pública nº 41/2015

Na primeira fase da Audiência Pública no 41/2015, ANEEL propôs a transferência de todo o universo de DIT, exceto aquelas em que se conectavam exclusivamente centrais geradoras ou consumidores.

No entanto, em que pese alguns problemas pré-existentes não tenham sido identificados pela ANEEL antes da abertura da Audiência Pública n 41/2015, fato é que esses problemas foram expostos durante as contribuições apresentadas pelos agentes. Nesse contexto, após a análise das contribuições apresentadas, entendeu que:

(i) De fato, a transferência da totalidade de DIT necessitaria da duplicação, em alguns casos, de infraestruturas existentes, o que necessitaria de investimentos e consequentemente haveria reflexo para o pagamento desses investimentos na tarifa a ser cobrada do consumidor;

(ii) Diversas DIT do universo proposto não estariam $100 \%$ amortizadas e depreciadas como inicialmente pressuposto pela ANEEL, dessa forma, haveria necessidade de pagamento de grande quantidade em dinheiro de indenização das distribuidoras para as transmissoras, o que afetaria o caixa das distribuidoras e consequentemente refletiria na tarifa para o consumidor; 
(iii) Não existem evidências concretas de que a transferência da totalidade das DIT estaria atrelada a uma necessária redução de tarifas para o consumidor;

(iv) Não restou comprovado eventual ganho de escala das distribuidoras em trabalhar com menor nível de tensão;

Ou seja, em que pese todos esses fatores sempre tenham existido e de fato pudessem ter sido aventados quando da abertura da primeira fase da Audiência Pública, foram levantados pela participação popular e posteriormente avaliados pela ANEEL.

A partir dessa avaliação, a ANEEL estudou três alternativas que entendeu viáveis para o caso:

(i) Transferir compulsoriamente apenas as DIT que atendiam a uma única distribuidora;

(ii) Transferir as DIT apenas por meio de acordo entre as partes, propondo regulamento de incentivo

(iii) Não regular e tratar apenas casos específicos.

Sobre a segunda e terceira alternativas, entendeu que ANEEL que a transferência voluntária das DIT sempre pode ocorrer, mas, em que pese tal possibilidade, poucos foram os casos de transferência voluntária.

\begin{abstract}
"Em uma análise inicial, já se descarta a segunda alternativa, proposta pelos interessados na AP. Tendo em vista que hoje os agentes já podem propor à ANEEL a transferência acordada das DIT e que poucos assim fizeram em mais de 18 anos, não há razão para esperar uma mudança de comportamento dos agentes. Nesse cenário, a norma proposta pela Abrate, Eletrosul e CTEEP seria pouco ou nunca utilizada. Assim, dentre as três alternativas, a segunda mostra-se a menos atrativa." (Fl. 13 da Nota Técnica n 0048/2016SRD/SRT/SCT/SRM/SGT/SFF/ANEEL, de 12/04/2016)
\end{abstract}

A partir de então a ANEEL passou a avaliar a alternativa 1, verificando se os custos com a transferência das DIT exclusiva seriam tão altos quanto os custos com a transferência de todo o universo de DIT.

Dessa análise, a ANEEL chegou à conclusão de que do universo de DIT que atendiam exclusivamente a uma distribuidora de energia elétrica, poucas ainda continham ativos anda 
não depreciados ou amortizados, o que diminuiria a necessidade de indenização às transmissoras e aliviaria as distribuidoras.

\begin{abstract}
Na proposta inicial, estava-se discutindo a transferência de 118 SE DIT, ativos em 385 SE RBF e 164 linhas de distribuição, que totalizavam 12,5 mil km de redes. As transferências envolviam uma RAP anual de cerca de R\$ 630 milhões, e geraria aproximadamente $\mathrm{R} \$ 1,5$ bilhão em indenizações por investimentos não amortizados. 75. A nova proposta é bem menos abrangente, envolve 40 SE DIT, nenhuma SE RBF e 101 linhas de distribuição, que somam pouco mais de 3,8 mil $\mathrm{km}$ de redes. A RAP anual é cerca de R $\$ 99$ milhões, e a indenização, pouco mais de R\$ 97 milhões. (Fl. 16 da Nota Técnica $\quad \mathrm{n}^{\circ} \quad$ 0048/2016-SRD/SRT/SCT/SRM/SGT/SFF/ANEEL, de $12 / 04 / 2016)$
\end{abstract}

Quanto ao prazo para o recebimento desses ativos, as áreas técnicas envolvidas propuseram acatar o quanto sugerido pelas distribuidoras e atrelar o recebimento das DIT eventualmente transferidas ao ciclo de revisão tarifária.

Diante desse cenário, a proposta constante da Nota Técnica $\mathrm{n}^{\circ}$ 0048/2016$\mathrm{SRD} / \mathrm{SRT} / \mathrm{SCT} / \mathrm{SRM} / \mathrm{SGT} / \mathrm{SFF} / \mathrm{ANEEL}$ foi a de se transferir apenas as DIT exclusiva que atendiam distribuidoras em um primeiro momento.

Note-se aqui que além de detalhada análise das contribuições dos agentes, a ANEEL também acabou por envolver outras superintendências na análise da questão, o que não havia ocorrido na primeira fase de discussões, visto que àquela foi analisada apenas pela SRD. Tal fator enriqueceu a discussão, trazendo à baila questões financeiras que antes eram apenas sugeridas e sugestionadas pela SRD, como por exemplo, a existência de ativos ainda não amortizados ou não depreciados em sua totalidade.

A proposta foi alvo de deliberação da diretoria da ANEEL que votou pela abertura da segunda fase de Audiência Pública de 28/04/2016 a 27/06/2016. A proposta, cujo escopo foi reduzido, foi sintetizada em minuta de resolução que previa o seguinte:

Tabela 9 - Síntese da minuta de resolução

Tema

DITs a serem DITS previamente listadas pela SRD, sendo divididas em Subestações e transferidas
Linhas. Nesse ponto, em que pese a Nota Técnica $\mathrm{n}^{\circ} 0048 / 2016$ -

$\mathrm{SRD} / \mathrm{SRT} / \mathrm{SCT} / \mathrm{SRM} / \mathrm{SGT} / \mathrm{SFF} / \mathrm{ANEEL}$ aventar a transferência apenas das DIT exclusiva já amortizadas ou depreciadas, a minuta de Resolução é silente quanto a esse tema. 
Tema

Prazo

Obras

previstas

Indenização

\section{Previsão na Resolução}

Primeira revisão tarifária das distribuidoras

já Obras já previstas devem ser executadas pelas transmissoras, mas podem ser executadas pelas distribuidoras mediante transferência e acordo.

Para obras/instalações ainda não depreciadas

Instalações já depreciadas devem ser transferidas sem ônus

Fonte: $2^{\circ}$ fase da Audiência Pública nº 41/2015.

A minuta recebeu contribuições de 24 agentes distintos, as quais podem ser observadas na tabela a seguir

Tabela 10 - Síntese das contribuições dos agentes

\begin{tabular}{ll}
\hline Instituição & Resumo da contribuição \\
ABRADEE & $\begin{array}{l}\text { Propõe que cada uma das distribuidoras } \\
\text { apresente cronograma detalhado e } \\
\text { personalizado para o recebimento das DIT. }\end{array}$ \\
Reitera a contribuição da primeira fase, \\
reforçando a necessidade de neutralidade de \\
impactos financeiros para as distribuidoras. \\
CEEE Geração & $\begin{array}{l}\text { A transferência das DIT, ainda que em menor } \\
\text { monta, ainda assim poderia ocasionar o } \\
\text { Transmissão }\end{array}$ \\
& cosequilíbrio econômico financeiro das \\
&
\end{tabular}

CELESC Distribuição Necessidade de apresentação de um Sim S.A cronograma de transferência que permita a neutralidade dos impactos financeiros.

CEMIG Necessidade de prever a neutralidade de Sim impactos financeiros para as Distribuidoras.

CHESF

Necessidade de observância do equilíbrio Concorda com a transferência das DIT exclusivas

Sim

Sim

Não econômico financeiro dos contratos de concessão.

Companhia

Contribuição relacionada a especificidades

Hidroelétrica

São técnicas do acesso da COMPANHIA

Patrício HIDROELÉTRICA SÃO PATRÍCIO a rede de distribuição.

COPEL GT

Contribuição relacionada a especificidades

Sim técnicas das linhas que constam no da minuta de Resolução proposta. 
Instituição

CPFL Energia

CTEEP

DEMEI

EDP

ELEKTRO

ELETROBRAS

ELETRONORTE

ELETROSUL

FNE

FURNAS
Resumo da contribuição

Contribuições relacionadas a necessidade de neutralidade jurídica para as distribuidoras que receberem os ativos em transferência.

Incompetência da ANEEL para determinar a Não transferência das DIT

Necessidade de manutenção do equilíbrio econômico financeiro do contrato de concessão.

Adequar a minuta de Resolução para que conste expressão relacionada a transferência exclusiva das "DIT de Uso exclusivo".

Contribuição relacionada a possibilidade de transferência negocial das DIT apenas em casos que seja comprovada a vantagem ao consumidor final.

Requer a manutenção da proposta inicial. Não

Entende pela competência da ANEEL para determinar a transferência das DIT.

Adequações quanto ao cronograma de recebimento das DIT.

O equilíbrio econômico financeiro dos Sim contratos deve ser observado quando da transferência dos ativos.

As DIT devem ser transferidas apenas com Não acordo entre as partes.

ANEEL não detém a competência necessária Não para determinar a transferência das DIT.

Equilíbrio econômico financeiro dos contratos de concessão devem ser mantidos.

ANEEL não possui a competência necessária Não para determinar a transferência das DIT

Deve ser mantido o equilíbrio econômico Sim financeiro dos contratos.

Reforça a possibilidade de transferência voluntária das DIT.
Concorda com a

transferência das

DIT exclusivas

Sim

Sim

Sim

Não

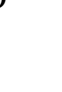

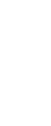




\begin{tabular}{|c|c|c|}
\hline Instituição & Resumo da contribuição & $\begin{array}{l}\text { Concorda com a } \\
\text { transferência das } \\
\text { DIT exclusivas }\end{array}$ \\
\hline LIGHT & $\begin{array}{l}\text { Necessidade de prever que as DIT não sejam } \\
\text { transferidas com nenhum passivo. }\end{array}$ & Sim \\
\hline Neonergia S.A & $\begin{array}{l}\text { Sugere que DITS que possam passar por um } \\
\text { arranjo estrutura para atender a uma única } \\
\text { distribuidora sejam classificadas como DIT } \\
\text { exclusiva }\end{array}$ & Sim \\
\hline $\begin{array}{lr}\text { Federação } & \text { dos } \\
\text { Trabalhadores } & \text { nas } \\
\text { Indústrias Urbanas do } \\
\text { Estado de São Paulo }\end{array}$ & $\begin{array}{l}\text { Falta de Competência para determinar a } \\
\text { transferência }\end{array}$ & Não \\
\hline $\begin{array}{l}\text { Siseltro Consultoria em } \\
\text { Engenharia }\end{array}$ & $\begin{array}{l}\text { Contribuição técnica relacionada a } \\
\text { necessidade de manter com as transmissoras } \\
\text { as os barramentos, módulos de conexão de } \\
\text { transformadores e interligação de barras, } \\
\text { reatores e bancos de capacitores, nas tensões } \\
\text { inferiores a } 230 \mathrm{kV} \text { e } 500 \mathrm{kV} \text { nas SEs de RB }\end{array}$ & Sim \\
\hline Grupo Energisa & $\begin{array}{l}\text { Contribuição técnica relacionada aos ativos } \\
\text { do Grupo Energisa. }\end{array}$ & Sim \\
\hline
\end{tabular}

Fonte: $2^{\circ}$ fase da Audiência Pública ${ }^{\circ}$ 41/2015

Como se observa da análise das contribuições realizadas, em que pese o escopo da proposta tenha sido significativamente reduzido, a ANEEL firmou o entendimento de que detinha a competência para determinação da transferência, o que novamente foi alvo de contribuições em sentido contrário.

No mais, as empresas pugnam pela necessidade de se manter a neutralidade de impactos financeiros e legais para as distribuidoras, bem como garantir a equação econômico financeira dos contratos de concessão afetados pela proposta.

c) A publicação da Resolução Normativa ANEEL 758/2017

Recebidas todas contribuições da segunda fase da Audiência Pública n ${ }^{\circ}$ 41/2015, as áreas técnicas da ANEEL passaram a avaliá-las de modo a subsidiar eventual decisão da diretoria da Agência sobre a publicação de ato normativo que versasse sobre a transferência das DIT. 
Ao total, foram recebidas 251 contribuições, aproveitadas ou rejeitadas de acordo com o quadro abaixo reproduzido, o qual consta em sua integralidade da Nota Técnica ${ }^{\circ}$ 0170/2016SRD/SRT/SCT/SRM/SGT/SFF/ANEEL, de 16/12/2016.

Figura 4 - Aproveitamento das contribuições da segunda fase da Audiência Pública no 41/2015

\begin{tabular}{|l|c|c|}
\hline \multicolumn{1}{|c|}{ Aproveitamento } & Quantidade & $\%$ \\
\hline Aceito & 27 & $10,8 \%$ \\
\hline Não aceito & 209 & $83,2 \%$ \\
\hline Parcialmente aceito & 12 & $4,8 \%$ \\
\hline Não se aplica & 3 & $1,2 \%$ \\
\hline TOTAL & $\mathbf{2 5 1}$ & $\mathbf{1 0 0 , 0} \%$ \\
\hline
\end{tabular}

Fonte: Audiência Pública nº 41/2015, Nota Técnica n 0170/2016-SRD/SRT/SCT/SRM/SGT/SFF/ANEEL

A respeito das contribuições relacionadas a transferência parcial das DIT, as superintendências responsáveis pela análise entenderam que:

(i) A competência da ANEEL pata determinar a transferência das DIT de modo compulsório e sem a chancela do poder concedente estaria refletida nos contratos de concessão de algumas das empresas afetadas pelo processo;

(ii) A transferência apenas negocial das DIT não satisfaria a necessidade regulatória, visto que tal transferência sempre se mostrou possível, mas nunca registrou números expressivos;

(iii) Durante a realização da $2^{a}$ fase da audiência pública $n^{\circ} 41 / 2015$ houve a publicação da Portaria do Ministério de Minas e Energia nº 120/2016, a qual determinada o modo de indenização dos ativos das transmissoras que haviam renovado suas concessões nos termos da Lei 12.783/103. Nesse modo, a indenização não seria mais paga pelo poder concedente e sim por meio de tarifa, o que aumentaria muito o valor da indenização a ser paga pelos ativos de DIT ainda não depreciados ou amortizados pelas distribuidoras às transmissoras.

(iv) Prazo para transferência das DIT iniciaria em 2018, após a revisão tarifária das transmissoras. 
Diante da análise realizada, foi proposta a aprovação de Resolução Normativa que determinasse a transferência compulsória das DIT exclusiva, dede que a essas não tivesse atrelada indenização relacionada a Portaria do Ministério de Minas e Energia nº 120/2016.

A matéria foi aprovada em reunião de diretoria colegiada da ANEEL de 07 de fevereiro de 2017, tendo sido publicada a Resolução Normativa nº758/2017 que "Estabelece as condições gerais para a incorporação das Demais Instalações de Transmissão - DIT no Ativo Imobilizado das concessionárias do serviço público de distribuição de energia elétrica".

A Resolução Normativa aprovada acabou por tratar dos temas expostos na tabela abaixo:

Tabela 11 - Resolução Normativa n ${ }^{\circ}$ 758/2017

\section{Tema $\quad$ Previsão na Resolução}

DITs a serem DIT exclusivas previamente listadas pela SRD, sendo divididas em transferidas Subestações e Linhas, desde que não contivessem indenização atrelada

Prazo Primeira revisão tarifária das distribuidoras

Obras já previstas Obras já previstas devem ser executadas pelas transmissoras

Indenização Para obras/instalações ainda não depreciadas

Instalações já depreciadas devem ser transferidas sem ônus

Fonte: Resolução Normativa n $^{\text {7 758/2017 }}$

\subsubsection{Desdobramentos e consequências da Audiência Pública nº 41/2015}

A Resolução Normativa $n^{\circ} 758 / 2017$ pôs fỉm a discussão pública relacionada a transferência das DIT, tendo estabelecido a transferência das instalações de interesse exclusivo desde que a essas não estivesse atrelada alguma indenização advinda da Portaria $n^{\circ} 120$ de 2016 do Ministério de Minas e Energia.

Assim, a partir da publicação da resolução a Aneel sedimentou seu entendimento de que teria plena competência para determinar a transferência da DIT.

No entanto, fato é que a transferência foi questionada por meio de ações judiciais que resultaram até mesmo na paralização da discussão do tema. 
Como se pode avaliar das contribuições relacionadas a Audiência Pública no 41/2015, muitas das transmissoras partes do processo, em especial a CTEEP e a ELETROSUL, contestaram a competência da ANEEL para determinar a transferência das instalações.

No entanto, fato é que não se pode atribuir esse questionamento, ao menos inicialmente, a uma avaliação falha das áreas técnicas responsáveis pela abertura da Audiência Pública. Isso porque, em 2015, quando da abertura do processo, a SRD estava respaldada por opinião da procuradoria que ressaltava a competência da Agência para determinar a transferência.

Mas, após a primeira fase da Audiência pública, os questionamentos tomaram corpo, tendo sido aventados no âmbito da Agência.

A CTEEP ingressou com pleito administrativo perante a ANEEL requerendo a imediata paralização do processo de audiência pública, visto que na visão da empresa, além da ANEEL não ter sequer competência para prosseguir com a discussão, também não teria atualizado o Banco de Preços de Referência.

Aqui, há que e destacar que toda a discussão relacionada a competência da ANEEL para determinar a transferência das DIT é balizada por dois principais argumentos: (i) a grande maioria das transmissoras afetadas pela determinação de transferência havia renovado suas concessões nos termos da Lei 12.783/2013; (ii) após a renovação das concessões, as empresas estavam aguardando a definição da indenização relacionada aos seus ativos não depreciados no momento da renovação; (iii) enquanto não recebiam a indenização, recebiam apenas receita para operar e manter, o que fez com que as finanças dessas empresas ficassem prejudicadas $^{18}$.

Dessa forma, a retirada das DIT em um momento financeiro crítico para as transmissoras, causou grande comoção no setor, o que levou as discussões postas.

\footnotetext{
${ }^{18}$ Nesse sentido, veja-se a explicação da CTEEP em sua contribuição a primeira fase da Audiência Pública no 41/2015. Disponível em https://www.aneel.gov.br/audiencias-publicasantigas?p_auth=MV8mLA3Y\&p_p_id=participacaopublica_WAR_participacaopublicaportlet\&p_p_lifecycle=1\&p_p_state= normal\&p_p_mode=view\&p_p_col_id=column2\&p_p_col_pos=1\&p_p_col_count=2\&_participacaopublica_WAR_participacaopublicaportlet_ideParticipacaoPublica=985 \&_participacaopublica_WAR_participacaopublicaportlet_javax.portlet.action=visualizarParticipacaoPublica
} 
Mas, além dessas questões, havia ainda uma discussão ainda mais intrínseca a transferência das DIT das transmissoras para as distribuidoras que era relacionada ao pagamento da indenização relacionada a transferência desses ativos para as distribuidoras.

Isso porque, algumas das instalações que seriam transferidas ainda não estariam totalmente depreciadas, o que, de acordo com as regras para pagamento de receita e retorno do investimento ao investidor de transmissão ${ }^{19}$ e ainda de acordo com o Artigo 36 da Lei 8.987 de $1995^{20}$ que "dispõe sobre o regime de concessão e permissão da prestação de serviços públicos previsto no art. 175 da Constituição Federal, e dá outras providências", ativos ainda não depreciados em sua integralidade e relacionados a prestação do serviço público, devem ser indenizados.

E é em razão do cálculo dessa indenização que CTEEP questionou a ANEEL. Assim, no entendimento da empresa, os preços pelos quais seria calculada a indenização deveriam ser definidos antes mesmo da determinação de uma possível transferência.

De modo que, em não estando definidos os preços base, o processo de transferência deveria ser interrompido até a exata definição.

Diante dessa demonstração de insatisfação e tendo em vista o não julgamento do pedido administrativo que requeria a revisão dos preços base para o cálculo de indenização, a CTEEP ingressou com demanda no judiciário autuada sob o $\mathrm{n}^{\mathrm{o}}$ 1004367-45.2015.4.01.3400.

A demanda, já julgada em primeira instância, determinou a paralização da discussão no âmbito da primeira fase da Audiência Pública nº 41/2015, decisão essa que foi posteriormente revertida.

Quanto a esse ponto, em que pese posteriormente o parecer da Procuradoria que pautou a abertura da Audiência Pública tenha sido alterado e que a CTEEP desde o início do processo tenha demonstrado o seu posicionamento em sentido contrário, não existem formas de se

\footnotetext{
19 Nesse sentido o Procedimento de Regulação Tarifária - PRORET, submódulo 9.1 Revisão Periódica das Receitas das Concessionárias de Transmissão. Disponível em: http://www2.aneel.gov.br/cedoc/aren2020880_2.pdf

${ }^{20}$ Art. 36. A reversão no advento do termo contratual far-se-á com a indenização das parcelas dos investimentos vinculados a bens reversíveis, ainda não amortizados ou depreciados, que tenham sido realizados com o objetivo de garantir a continuidade e atualidade do serviço concedido
} 
atribuir esses questionamentos a uma falha das áreas técnicas, de forma que não havia como prever que os questionamentos dos agentes levariam a paralização das discussões em razão de decisões judiciais.

No entanto, o mesmo não se observa quanto a redução expressiva de escopo da Audiência Pública. Isso porque, os pontos levantados pela Agência para que fosse determinada a redução poderiam ter sido aventados já na primeira fase da Audiência Pública visto que sempre estiveram a disposição da Agência.

Veja-se, por exemplo, a questão da indenização atrelada as instalações. O nível de depreciação dos ativos a serem transferidos poderia ter sido estudado para verificar a necessidade de indenização antes mesmo da discussão pública. No entanto, em razão da inexistência desse estudo foram necessários dois anos de discussão para que essa informação fosse efetivamente levada em consideração.

Outro ponto importante é relacionado a necessidade de duplicação de estruturas e sistemas em caso de transferência da totalidade das informações. Como agência técnica e tendo amplo acesso ao ONS, esse estudo poderia ter sido realizado antes mesmo da proposta que transferência total das DIT.

Não se pretende, com as referidas pontuações, anular o processo de participação pública cujo objetivo é de fato diminuir a assimetria de informações entre regulador e regulador e trazer a luz questões que não foram anteriormente aventadas pelo regulador e que são importantes para o processo de tomada de decisão.

No entanto, considerando que o caso em questão passou por um processo de Análise de Impacto Regulatório, espera-se que esse processo seja capaz de capturar os problemas, se não todos, os mais relevantes.

3.2.2.1. Desdobramentos e consequências da Audiência Pública no 41/2015: o problema ainda persiste

Como analisado, a implementação da proposta inicial de transferência da totalidade das DIT das Transmissoras para as Distribuidoras não se demonstrou viável, não apenas em razão 
do patente questionamento quanto a legalidade da transferência, que culminou até mesmo na propositura de demanda judicial em face da ANEEL no intuito de paralisar a discussão, mas especialmente em razão da inviabilidade técnica e financeira demonstrada.

Tal inviabilidade se deveu, primeiramente em razão da premente necessidade de duplicação de instalações, pela afetação financeira da atividade das distribuidoras, que receberiam uma gama de ativos que demandariam investimentos em operação e manutenção sem a contrapartida imediata de receita, bem como pela existência de grande volume de dinheiro relacionado a indenização que seria devida as transmissoras de energia elétrica, uma vez que no decorrer do processo de estudos da transferência proposta foi publicada a Portaria n $120 / 2016$ do Ministério de Minas e Energia.

Todos os problemas regulatórios identificados durante o percurso resultaram na necessidade de uma importante diminuição da gama de ativos demandados para transferência.

Ocorre que os questionamentos relacionados a transferência das DIT não cessaram necessariamente com a finalização da Audiência Pública no 41/2015 ou mesmo com a publicação da Resolução Normativa nº 758/2017.

Nesse contexto, veja-se recente discussão travada entre CTEEP e ELEKTRO relacionada a realização de reforços e melhorias em instalações classificadas como DIT.

É que, no decorrer de processo administrativo ${ }^{21}$ em que a CTEEP requeria a autorização para realização de obras em algumas de suas instalações classificadas como DIT, a SRT em conjunto com a SCT iniciou um processo de transferência compulsória de DIT para a ELEKTRO. Ao final do processo, em razão da necessidade de se realizar obras céleres nessas instalações, e tendo em visto que o processo de autorização para realização dessas obras já estava em tramite para a CTEEP, as instalações acabaram por não ser transferidas.

Em que pese a CTEEP tenha manifestado um interesse genuíno em manter as instalações e continuar com o processo de autorização para realização das obras em questão, as superintendências manifestaram a tese no sentido de que a Resolução Normativa $n^{\circ}$ 758/2017

\footnotetext{
${ }^{21}$ Processo 48500.003884/2015-34. Disponível em www.aneel.gov.br. Acesso em 12 de out. de 2020.
} 
não determina apenas a transferência de instalações exclusivas e que não detenham qualquer indenização atrelada, sendo essas apenas recomendações quanto à aplicação da norma.

De fato, ao se analisar o texto legal da Resolução Normativa $n^{\circ} 758 / 2017$, não há qualquer menção a transferência apenas das DIT exclusiva ou que não detenham indenização atrelada, havendo, em tese, a possibilidade de a ANEEL determinar qualquer transferência relacionada às DIT.

Poder-se-ia argumentar, no entanto, que os documentos integrantes da Audiência Pública n ${ }^{\circ}$ 41/2015 são e devem ser parte da interpretação da norma. Uma visão mais legalista e literal na norma, porém, poderia aplicá-la em sua integralidade, determinando a transferência de toda a transferência das DIT, visto que o texto legal não mencionava nada sobre a restrição à transferência das DIT exclusiva.

Com tal posicionamento, a ANEEL sedimenta o seu entendimento sobre o tema, cravando seu posicionamento no sentido de que pode, a qualquer momento, determinar a transferência de DIT se entender que essa transferência atende ao interesse público.

Isso significa dizer que o assunto, assim que determinada a transferência de mais instalações e ao passo que as indenizações previstas para essas mesmas instalações sejam pagas, voltará a pauta de discussão da Agência.

\subsubsection{A AIR e as DIT}

Como analisado, a determinação de transferência compulsória das DIT envolveu grande esforço da ANEEL, tendo aberto diversas oportunidades de debate sobre o tema.

Também como já analisado, todo o processo de tomada de decisões da ANEEL envolve diversas etapas sem as quais a publicação de um determinado normativo não se torna possível.

Dentre as etapas, que envolvem a publicação de um ato na ANEEL, encontram-se a realização da AIR e a etapa de consulta pública, ambas realizadas para a publicação da Resolução que determinou a transferência das DIT. 
Para a publicação da Resolução Normativa ${ }^{\circ}$ 758/2017 foi realizado processo de AIR, tendo sido esse publicado de acordo com as regras previstas na Resolução Normativa $n^{\circ}$ 540/2013 vigente a época.

É bem verdade que o modelo de AIR determinado pela Resolução Normativa ${ }^{\circ}$ 540/2013 foi revisado visto que na avaliação da ANEEL não cumpria o seu papel como instrumento de tomada de decisão, tendo se tornado mais um formulário para preenchimento adicional ao trabalho realizado pela Agência. No entanto, considerando que esse era o modelo vigente quando da abertura da Audiência Pública nº 41/2015, a análise da presente investigação se concentrará nele.

Mas, para iniciar a análise da AIR realizada pela ANEEL, vale rememorar algumas das principais atribuições dessa ferramenta.

Assim, como já mencionado, a AIR é uma ferramenta sistemática que pretende apontar quais os caminhos regulatórios são possíveis para um problema verificado. Para que seja efetiva, a ferramenta deve observar alguns parâmetros e etapas, as quais foram sistematizadas pela Casa Civil (2018):

(i) Qual o problema regulatório a ser tratado

(ii) Qual a consequência de não correr qualquer intervenção

(iii)Quem é afetado pelo problema

(iv)Quais as alternativas possíveis para a solução do problema apresentado

(v) Seleção de dados para análise do custo $\mathrm{x}$ benefício/custo $\mathrm{x}$ efetividade de cada uma das medidas

(vi)Análise e comparação das alternativas

(vii) Elaboração da AIR

(viii) Consulta Pública

(ix) Possível ajuste da AIR com base nos dados da consulta Pública

(x) Tomada de decisão

(xi) Monitoramento da medida 
Assim, resta avaliar se a AIR realizada pela ANEEL cumpriu com os requisitos do que a Casa Civil considera como essenciais para a realização de uma avaliação e se também foram seguidos os requisitos da Resolução Normativa nº 540/2013.

A AIR realizada para a abertura da Audiência (Anexo I) foi realizada em conjunto com a Nota Técnica $\mathrm{n}^{\circ}$ 0032/2015-SRD/ANEEL e de fato apresentou o quanto determinado pela Resolução Normativa $n^{\circ}$ 540/2013. A análise da AIR realizada é apresentada na tabela abaixo:

Tabela 12 - Análise da AIR ANEEL

\begin{abstract}
Pontos essenciais Tratamento dado pela ANEEL da AIR

O problema Sim, o problema regulatório foi identificado. De acordo com a regulatório foi ANEEL foi observado que as DIT são instalações que exercem identificado? funções típicas de distribuição e que estavam sendo operadas por transmissoras.
\end{abstract}

A consequência do A hipótese da ANEEL era no sentido de que a operação de DIT por problema foi identificada? transmissoras tornaria a operação dessas instalações mais cara e mais morosa

Os grupos afetados Sim, Distribuidoras, transmissoras de energia elétrica e usuários foram identificados? finais.

As causas do Sim, de acordo com o levantamento da ANEEL, a morosidade problema foram apontada se deve ao fato de que ao serem operadas por transmissoras, identificadas as DIT devem obedecer ao planejamento dessas empresas, que se dá de modo centralizada e com autorização do poder concedente. Com a transferência para as distribuidoras as obras necessárias seriam realizadas de modo mais rápido, visto que o planejamento da distribuição é local.

Qual a justificativa A transferência das DIT para as distribuidoras resultaria em menor para intervir? morosidade para realização de obras, diminuindo o custo para o consumidor.

Os objetivos da Sim, atribuir às distribuidoras as funções típicas de distribuição, com intervenção foram diminuição dos prazos para obras e custos para o consumidor. estabelecidos?

Foram consideradas Sim. Foi considerada a opção de não regular. outras opções regulatórias?

Foi realizada análise Foi realizada em tese, sem análise de dados concretos. de custo benefício?

Foi realizada Sim, em duas fases de discussão distintas. consulta pública? 
A primeira análise realizada leva a conclusão de que de fato a ANEEL realizou a devida análise para a publicação da Resolução Normativa n ${ }^{\circ}$ 798/2017, no entanto, da avaliação efetiva da AIR percebe-se pouca profundidade das análises realizadas.

Analise-se, por exemplo, a questão relacionada ao objetivo e as consequências da nova norma. Nesse ponto, a ANEEL faz conjecturas sobre um possível aumento de custos e prazo para realização de obras em DIT, o que impactaria diretamente o consumidor final. No entanto, não foram avaliadas questões como:

(i) Qual o prazo médio de atraso de obras em razão de sua realização pelas transmissoras?;

(ii) Qual o incremento de custo que a operação dessas instalações pelas transmissoras ocasiona ao sistema?

Desse modo, muito embora a ANEEL levante algumas hipóteses em sua AIR, não reponde a perguntas ou apresenta dados para garantir a fidedignidade das afirmações apresentadas.

Nesse contexto, vale mencionar que o sucesso da realização de uma AIR depende da avaliação precisa de dados relacionados as hipóteses levantadas, o que não ocorreu no presente caso.

Outro ponto é relacionado as opções regulatórias para o tema de transferência das DIT, muito embora existam diversas opções para regular o tema como por exemplo: (i) transferir apenas uma classe de DIT; (ii) transferir apenas DIT que atendam exclusiva e permanentemente as distribuidoras; (iii) não regular o tema. No entanto, apenas a alternativa relacionada a transferência total das DIT foi considerada.

Mas, o ponto mais crítico é relacionado a análise custo $\mathrm{x}$ benefício, visto que a análise realizada também não se baseou em dados relativos aos custos atribuídos a operação das DIT pelas transmissoras, mas sim em meras conjecturas realizadas pela ANEEL. 
Em que pese a análise da AIR não tenha se baseado em dados concretos há que se considerar que a etapa de audiência pública pode ser considerada como efetiva e bem sucedida, visto que oportunizou manifestação dos agentes, ocasionando até mesmo a mudança da conclusão final sobre a necessidade de transferência de todas as DIT.

Desse modo, pela análise da documentação relacionado a AIR, não há como dizer que a ANEEL não seguiu os parâmetros impostos pela Resolução Normativa no 540/2013, no entanto, o fato é que a análise das premissas adotadas não se baseou em dados concretos e apurados e sim em meras afirmativas. Tal afirmativa pode ser comprovada pela leitura das notas técnicas, que sempre se referem aos dados como dados em tese.

O que se percebe, assim, é que a análise da AIR que respaldou a abertura da Audiência Pública n 41/2015 apenas corrobora o estudo já realizado pela ANEEL que culminou na reformulação das diretrizes da AIR na Agência, no sentido de que as análises realizadas não continham a profundidade necessária para que a AIR se tornasse efetivamente uma ferramenta de tomada de decisão.

Ou seja, em que pese a AIR do presente caso tenha caminhado no sentido de perceber as principais questões relacionadas a transferência das DIT, as hipóteses não foram confirmadas por meio de dados analíticos e concretos que permitissem a sua confirmação.

Conclui-se, portanto, que nos moldes realizados a AIR realizada não continha a efetividade e profundidade necessária para que seu objetivo fosse de fato alcançado.

\subsubsection{A AIR poderia ter previsto os desdobramentos do caso?}

Um dos principais objetivos relacionados a presente investigação é relacionado a avaliação da possibilidade de a AIR ter previsto as intercorrências relacionadas a transferência das DIT, em especial: (i) os questionamentos relacionados a ausência de competência da ANEEL para determinar a transferência das DIT; (ii) as intercorrências financeiras relacionadas a transferência das DIT que acabaram por impedir a transferência completa das instalações; (iii) os custos adicionais que a transferência completa das instalações traria para o sistema elétrico. 
Como se observa, nenhuma das questões, em que pese tenham surgido durante a condução do processo de participação pública, não foram avaliadas durante a AIR.

De fato, quanto a questão relacionada a competência da Agência para determinar a transferência das DIT, observa-se que a SRD responsável pela primeira análise agiu corretamente quando da realização da AIR, questionando a procuradoria da Agência sobre a referida competência. Assim, a SRD busco dados especializados quanto ao tema, não havendo espaço para questionamento de um fato jurídico pela área técnica.

Nesse ponto, entende-se que a AIR não poderia ter contribuído para prever os desdobramentos e questionamentos relacionados ao tema, visto que a análise da SRD se pautou em opinião especializada sobre o tema.

O mesmo não ocorre, no entanto, com relação aos demais pontos que foram observado durante o processo de participação popular. Nesse contexto, inicialmente a AIR da ANEEL apontou que a transferência total das DIT seria possível uma vez que grande parte das instalações classificadas como DIT estariam totalmente amortizadas ou depreciadas, o que permitiria a transferência das instalações sem qualquer intercorrência ou necessidade de pagamento de indenização das distribuidoras para as transmissoras.

No entanto, tal afirmativa que pautou todo o processo de transferência das DIT e abertura da Audiência Pública no 41/2015 não foi confirmada por meio de dados pela SRD. Nesse contexto, considerando que a análise foi realizada pela área técnica e havendo a possibilidade de essa, como parte integrante da Agência Reguladora, requisitar o envio de informações aos Agentes, podendo confirmar ou não a hipótese aventada.

Ainda sobre esse ponto, vale mencionar que a época da abertura da Audiência Pública $n^{\circ} 41 / 2015$, ainda não estava definida qual seria indenização das transmissoras que renovaram as suas concessões nos termos da Lei 12.783/2013. Isso significa dizer que a época da abertura da Audiência Pública n ${ }^{\circ}$ 41/2015 não havia uma definição de como se pagaria eventual indenização das transmissoras, não havendo a possibilidade de se determinar que não haveria indenização a ser paga. 
Esse é o tipo de informação que seria possível prever em uma AIR caso os dados concretos da matéria tivessem sido solicitados.

Outro ponto é quanto a necessidade de duplicação de instalações em caso de transferência das DIT. Tal fator não foi previsto quando da análise realizada pela ANEEL, mas uma avaliação técnica e consulta prévia de dados aos agentes envolvidos poderia ter apontado tal necessidade, visto que muitas dessas instalações compartilham sistemas de monitoramento e proteção que devem ser operados pelas transmissoras.

Dessa forma, em sendo transferidos os ativos, as transmissoras deveriam instalar novamente em seus equipamentos sistemas de monitoramento e controle, adequando as instalações que restariam. Essas obras, por óbvio, deveriam ser remuneradas as empresas, o que acarretaria em gastos extras e aumento de tarifa aos consumidor final, objetivo contrário ao perseguido pela ANEEL quando da abertura da discussão.

Assim, o que se percebe da análise realizada é que alguns dos pontos cruciais que foram determinantes para a conclusão da transferência apenas das DIT exclusiva poderiam ter sido levantadas ainda na fase da AIR, visto que sempre estiveram disponíveis para análise da Agência.

Mas, em que pese a AIR não tenho sido efetiva o suficiente para antecipar questões relacionadas a proposta de regulação, há que se ressaltar que no caso em análise as duas fases de Audiência Pública de prestaram a coletar valiosos e importantes dados sobre o tema, que permitiram uma nova conclusão da ANEEL sobre o assunto.

\subsection{Pesquisa empírica}

De forma a obter a percepção dos agentes participantes do processo de transferência das DIT, um formulário (Anexo II) com algumas questões relacionadas as DIT e a eficiência dos processos de AIR e participação pública. Nesse contexto, os formulários foram enviados para as empresas ELEKTRO, CPFL, EDP, CEEE, COPEL GT, CEMIG GT, CTEEP, FURNAS, ELETRONORTE, ELETROSUL e CHESF GT, tendo sido respondido por 9 representantes das referidas empresas. Os formulários foram enviados via e-mail entre janeiro e março de 2020, ressaltando a confidencialidade da identidade dos participantes. 
A análise dos dados revela que, em que pese os agentes demonstrem confiança no processo de participação pública da ANEEL, por vezes o entendem como um simples processo burocrático, que não agrega valor a regulação final.

Em que pese a análise do caso das DIT tenha demonstrado grande influência das contribuições realizadas na regulação final que culminou na determinação da transferência das DIT exclusivas, os agentes ainda demonstram a necessidade de se aprimorar o processo de participação social a fim de que esse cumpra o seu objeto.

a) Dados gerais da pesquisa e perfil dos participantes

Dos 9 participantes da pesquisa, 77,8\% detém cargos de gerência ou diretoria, o que reflete em uma análise voltada aos negócios das empresas participantes dos processos de consulta ou audiência pública realizados pela ANEEL.

Figura 5 - Porcentagem de gerentes e diretores participantes da pesquisa

Qual o seu cargo na empresa em que trabalha?

9 responses

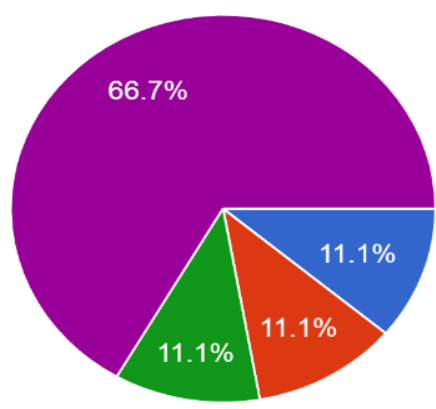

Analista regulatório

Advogado

Engenheiro

Coordenador

Gerente

Diretor

Dos participantes, apenas 1 distribuidora respondeu a pesquisa. Da análise realizada, a baixa adesão das distribuidoras se refere ao fato de que tais empresas tem maior interesse na transferência efetiva das DIT. 
Figura 6 - quantidade de distribuidoras e transmissoras participantes da pesquisa

A empresa em que você trabalha se enquadra como transmissora ou distribuidora de energia elétrica

9 responses

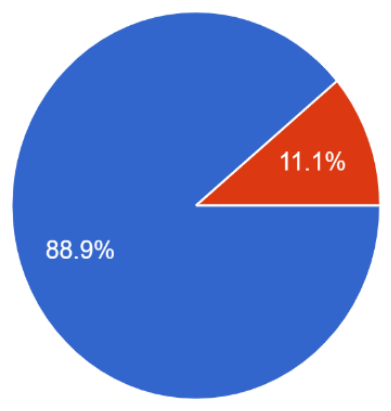

Transmissora

Distribuidora

Todas as empresas participantes da pesquisa continham em sua base de ativos em operação equipamentos classificados como DIT, sendo a maioria (77.8\%) afetadas em maior ou menor grau pela transferência

Figura 7 - Existência de DIT na base de ativos das empresas participantes da pesquisa

A empresa em que você trabalha contém em sua base de ativos Demais Instalações de Transmissão - DIT?

9 responses

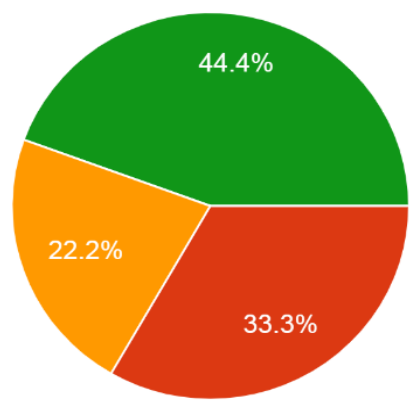

Não

Pouco

- Razoavelmente

Muito 
Figura 8 - Participantes afetados pela determinação de transferência das DIT

A empresa em que você trabalha foi afetada pela proposta de Transferência das Demais Instalações de Transmissão - DIT incluída na Audiência Pública nº 41/2015 promovida ANEEL 9 responses

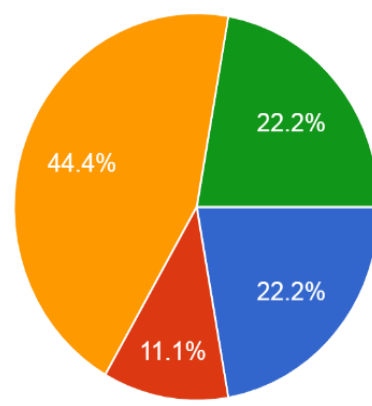
Não
Pouco
Razoavelmente
Muito

b) Audiência Pública nº 41/2015

Na opinião dos participantes, a condução da audiência pública $n^{\circ}$ 41/2015 oportunizou a participação dos agentes, no entanto, se mostrou pouco aberta a opiniões diversas daquelas colocadas em Audiência Pública.

Figura 9 - Oportunização da ampla manifestação dos agentes na visão dos participantes da pesquisa

Na sua opinião, a Audiência Pública n 41/2015 oportunizou a ampla manifestação dos agentes? 9 responses

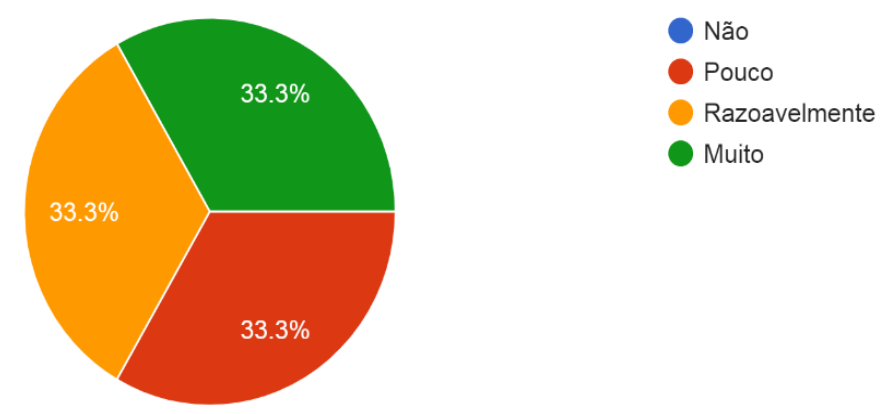


Na sua opinião, na condução da Audiência Pública n 41/2015, a ANEEL se mostrou aberta a acatar opiniões e soluções diversas daquelas já postas no âmbito da Audiência Pública?

9 responses

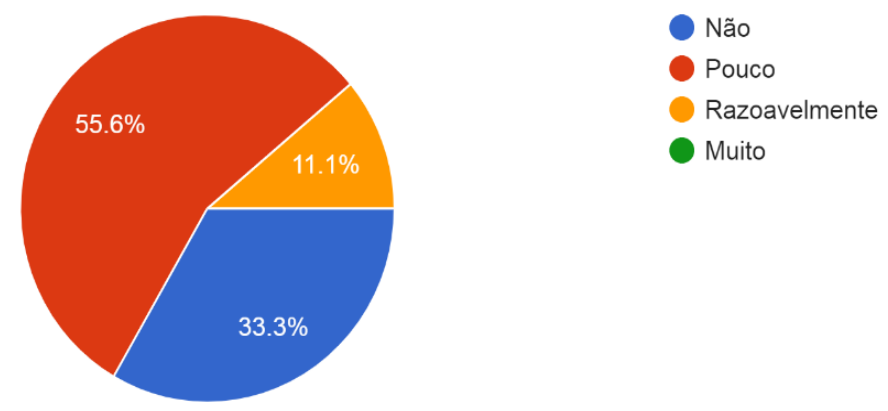

Nesse ponto, de fato, se analisarmos apenas as contribuições relacionadas a manifestação quanto a não transferência das DIT e considerando que a grande maioria dos participantes são representantes de transmissoras que em sua maioria não concordavam com a determinação de transferência, a pesquisa reflete o que ocorreu na prática. No entanto, há que se ressaltar que a Audiência Pública no 41/2015 teve grande relevância para alterar o resultado final da determinação de transferência, tendo sido observadas diversas contribuições dos agentes com relação aos prazos para recebimento das DIT, bem como sobre a existência de indenização relacionada a esses ativos.

Vale ressaltar que em que pese a maioria 55,6\% dos agentes participantes tenha se manifestado no sentido de que a ANEEL na condução da Audiência Pública não tenha se demonstrado aberta a ouvir opiniões diversas das já colocadas, 66,7\% dos participantes considera que a decisão final sobre a transferência das DIT se demonstrou razoável do ponto de vista técnico ou regulatório.

Na nossa avaliação, tal resultado reflete a condução da Audiência Pública nº 41/2015 da qual se extraíram dados que permitiram a alteração da regulação. 
Figura 11 - Conhecimento sobre o resultado final da Audiência Pública no 41/2015 pelos participantes da pesquisa

Você conhece o resultado final da Audiência Pública n 41/2015?

9 responses

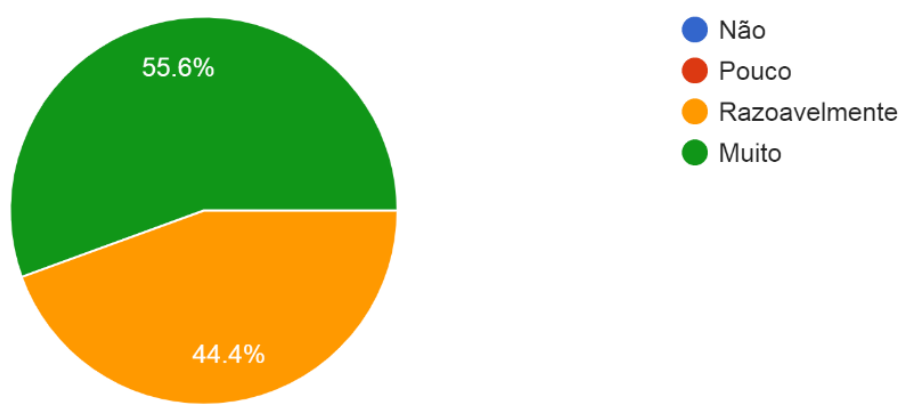

Figura 12 - Opinião sobre a melhor alternativa técnica e regulatória na visão dos participantes da pesquisa

Você considera que a decisão de transferência das Demais Instalações de Transmissão - DIT considerou a melhor alternativa técnica, regulatória e financeira?

9 responses

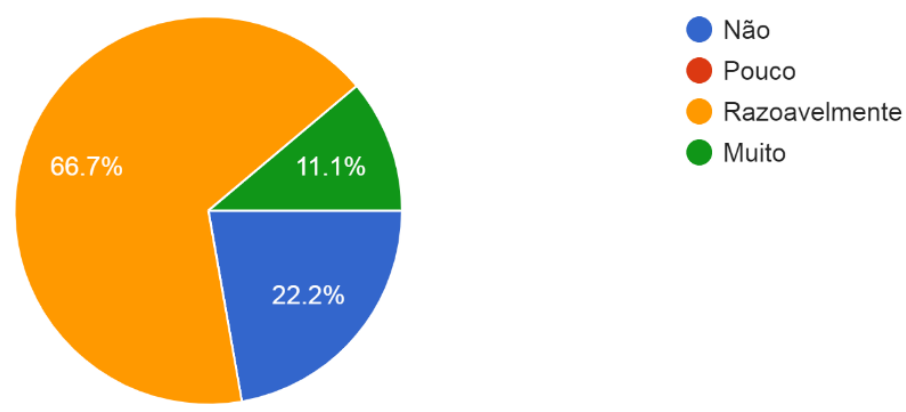

c) Análise de Impacto Regulatório

A pesquisa também pretendeu avaliar a percepção dos agentes sobre a utilização da AIR como um instrumento de tomada de decisão pela ANEEL.

Nesse contexto, todos os participantes afirmaram conhecer em maior ou menor grau a disponibilidade de utilização da ferramenta no âmbito da ANEEL. 
Você conhece a Análise de Impacto Regulatório

9 responses

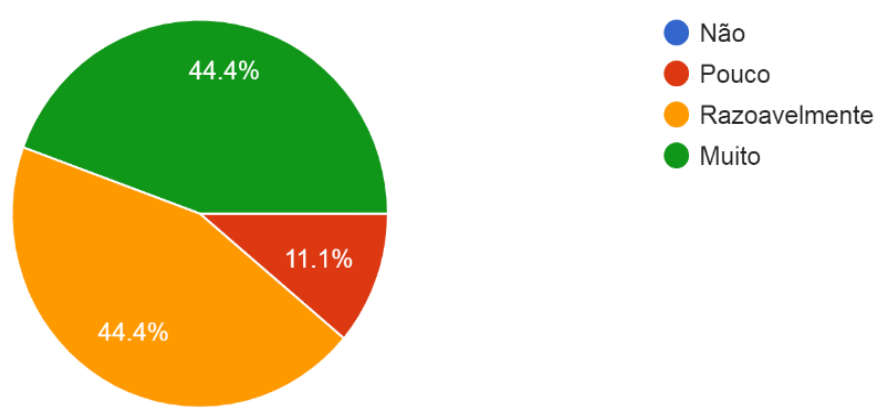

Pretendeu-se ainda avaliar a suficiência da AIR realizada. Nesse quesito, as opiniões dos participantes se demonstraram divergentes. Assim, 44,4\% acreditam que caso a AIR tivesse sido aplicada adequadamente seria pouco provável a possibilidade de determinação da transferência, 22,2\% acreditam que a transferência teria sido proposta de forma razoável, enquanto $33,3 \%$ entendem que a transferência não teria ido proposta.

Há que se avaliar, nesse resultado, que parte dos participantes por serem representantes de transmissoras de energia elétrica, detém interesses diversos e não relacionados a transferência das DIT, de forma que o resultado do referido quesito pode refletir essa dualidade entre transmissoras e distribuidoras quanto ao tema.

Figura 14 - Proposição da transferência das DIT e suficiência da AIR na opinião dos participantes da pesquisa 
Na sua opinião, caso tivesse sido feita a Análise de Impacto Regulatório para o caso das Demais Instalações de Transmissão - DIT, a sua transferência teria sido proposta?

9 responses
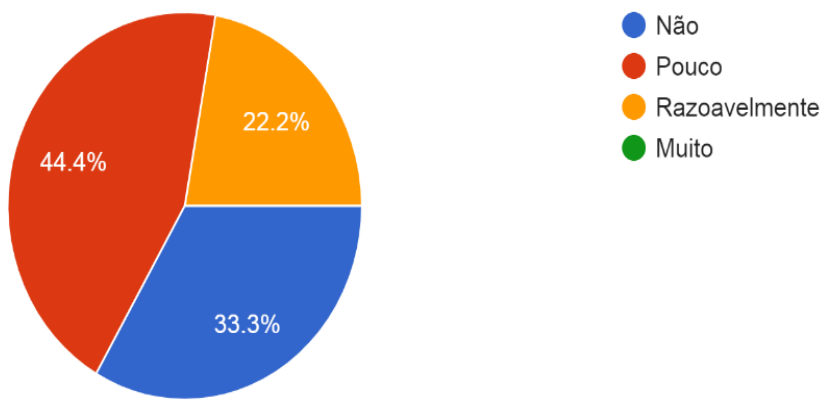

Também, ainda sobre a AIR foi realizada questão aberta relacionada a possível relação entre a AIR e a decisão tomada pela ANEEL no sentido de transferir as DIT. As respostas dadas a essa pergunta, confirmam, de certa forma a análise até então efetuada na presente investigação.

Como visto, em que pese a ANEEL tenha cumprido com as etapas necessárias para a propositura de um regulamento que impacta diretamente em direitos e obrigações de concessionários de energia elétrica pela análise dos documentos que pautaram a decisão final da Agência, poucos foram os dados analisados a fundo que pudessem confirmar as afirmativas utilizadas pela ANEEL para determinar a transferência.

Essa percepção é confirmada pelos agentes em alguns trechos das respostas à pergunta realizada:

"Ao tratar de forma genérica não se oportunizou melhores soluções técnicas e financeiras."

"A Análise de Impacto Regulatório deve ser feita de forma prévia a abertura de Consulta Pública e de maneira abrangente, contemplando todas as possíveis alternativas da nova regulamentação e seus respectivos impactos, de forma que a proposta final não fique restrita a visão do regulador ou a paradigmas previamente estabelecidos."

“Acredito que sempre uma maior discussão e um planejamento prévia, como o caso do AIR, acarreta em melhores resultados. Entretanto, existem interesses distintos das partes que por vezes impede a melhor orientação para os casos, gerado por vezes pela assimetria de informações entre os agentes.” 
"Penso que a análise de impacto regulatório deve apresentar a estimativa de redução na tarifa ao consumidor final, e melhoria nos indicadores de qualidade (DEC e FEC) em relação a situação existente. Na AP 41/2015 houve manifestações que a transferência traria estes benefícios, mas sem apresentar sequer uma metodologia pra estimar a economia e a redução dos indicadores. Mas a verdade é que a Transmissora gostaria de apresentar esta conta pra provar que o custo pra sociedade aumentará, e a Distribuidora o contrário. Como o cálculo depende de informações dos dois, obviamente um não fornecerá informação pro outro de forma espontânea."

As respostas apontam principalmente pela necessidade de se oportunizar a ampla manifestação dos agentes na construção da melhor opção regulatória ainda na fase da AIR, o que à época da condução da Audiência Pública nº 41/2015 não era previsto, falha corrigida posteriormente pelo regulador. Apontam ainda sobre a necessidade de confirmação, por meio de dados concretos das hipóteses aventadas pela ANEEL.

Ponto interessante abordado nas respostas é relacionado a assimetria de informações apresentadas pelas transmissoras e pelas distribuidoras, visto que atuam com evidente interesse divergente na matéria.

De fato, a assimetria de informação no levantamento de dados para a realização de uma AIR é um fato relevante e deve ser tratado, no entanto, não pode servir de argumento para que dados reais e concretos sejam levantados e analisados para a confirmação das hipóteses do regulador.

A confirmação dessas hipóteses deve ser etapa essencial do processo de AIR para que sejam evitados esforços não necessários por parte do regulador.

3.2.3.2. A efetividade, adequação e eficácia dos processos de AIR e participação pública no caso das DIT

Como já mencionado, um dos principais objetivos da presente investigação é o de avaliar se os processos de tomada de decisão e utilização das ferramentas a disposição do regulador são efetivos e adequados aos processos de tomada de decisão no âmbito da ANEEL.

Pelo corte metodológico realizado, quanto utilizadas, as palavras efetivo, adequado e eficaz tem os significados atribuídos na seção 1 da presente investigação. 
Nesse contexto, se considera adequado um processo de AIR que considere e cumpra com as premissas estabelecidas na resolução Normativa que o regula perante a ANEEL.

Como eficaz, se considera uma AIR que de fato auxilie e demonstre as alternativas regulatórias pertinentes e possíveis para o problema apresentado. Já como efetivo se considera um processo que chegue ao seu objetivo final, qual seja, o de ser instrumento para tomada de decisão.

Pela avaliação da AIR realizada no caso da determinação de transferência das DIT, observa-se que esse de fato cumpriu com todas as etapas previstas na Resolução Normativa ${ }^{\circ}$ 540/2013, de modo que se adequou o quanto regulado.

No entanto, não há como considerar que o processo atingiu os objetivos de eficácia e efetividade, visto que não analisou dados concretos relacionados as premissas iniciais postas pela ANEEL.

Assim, a avaliação tornou-se incompleta, não servindo como base para tomada de decisão, passando a fazer parte de mais uma etapa burocrática e ineficiente para tomada de decisão, visto que as hipóteses aventadas não eram discutidas e confirmadas por dados reais e avaliáveis. Por outro lado, o mesmo não se observou com a Audiência Pública realizada, que, mesmo sendo parte do processo de AIR, se prestou a avaliar os diferentes pontos de vista sobre o tema, tendo sido instrumento fundamental para coleta de dados que levou a conclusão de necessidade de transferência parcial das DIT.

\subsection{CONCLUSÃO PARCIAL}

O processo de tomada de decisão regulatória na ANEEL, em especial quando relacionado a implementação de uma nova regulamentação, desde 2013, deve necessariamente passar pela execução de uma AIR.

A AIR, a partir da identificação de um problema regulatório a ser tratado, deve identificar as consequências dos problemas existentes, definir os objetivos de uma possível intervenção, as modalidades de intervenção, além dos custos x benefícios de cada uma dessas intervenções, bem como as vantagens e desvantagens da intervenção relacionada a determinado 
problema. Todo o processo de AIR também deve ser submetido a etapa de participação pública, de modo e tentar equalizar a assimetria de informações típica de mercados regulados.

Desde sua primeira versão, em 2013, a AIR na ANEEL vem passando por processo de aprimoramento regulatório, de modo que em 2017, foi publicada nova regulamentação sobre o tema, a Resolução Normativa $n^{\circ}$ 798/2017, que teve por objetivo atualizar a AIR aplicada na Agência para que essa correspondesse as orientações da OECD e da CASA CIVIL, o que, de acordo com a Agência, tornaria o processo mais efetivo e participativo.

Considerando o histórico de implantação da AIR na ANEEL, foi avaliado processo de implantação de importante Resolução Normativa que teve por objetivo principal a determinação de transferência das DIT das transmissoras para as distribuidoras.

A partir da identificação de um possível problema regulatório, qual seja, a operação de instalações de distribuição por empresas de transmissão (considerando que DIT são instalações que historicamente e no âmbito regulatório não tem tensão Rede Básica - instalações tipicamente operadas por transmissoras - e operaram abaixo de $230 \mathrm{kV}$, a ANEEL realizou estudos, acompanhados de AIR, baseados em hipóteses que confirmariam a existência de um problema e a necessidade de intervenção da ANEEL.

Com base na Resolução Normativa n 540/2013, foi realizado então a AIR e aberta a primeira fase da Audiência Pública nº 41/2015.

Na abertura da Audiência Pública nº 41/2015 a ANEEL propôs a transferência de toda e qualquer instalação de DIT operada por transmissoras que de algum modo atendessem as instalações de distribuição. Dentre as premissas adotadas que justificavam a intervenção estavam a morosidade das transmissoras na realização de obras, maior custo de operação dessas instalações pelas transmissoras, bem como a inexistência de indenização ser paga pelas distribuidoras às transmissoras.

Embora a AIR realizada tenha adotado essas premissas, de fato, não se valeu de dados concretos para validá-las, realizando inclusive a análise custo $\mathrm{x}$ benefício pautada na veracidade absoluta dessas premissas. 
Nesse contexto, o que se percebe é que, em que pese a AIR realizada tenha seguido as premissas da Resolução Normativa $n^{\circ} 540 / 2013$ vigente a época, deixou de aprofundar os estudos necessários que levariam as conclusões indicadas por meio das fases de Audiência Pública.

Assim, o que se concluir é que, em que esse a época a ferramenta de AIR estivesse disponível, não foi corretamente utilizada, pela falta de análise de dados concretos sobre as premissas inicialmente levantadas.

Por outro lado, a Audiência Pública foi utilizada de modo a avaliar o posicionamento dos agentes sobre os temas postos como premissas, sendo utilizada de modo a melhorar a proposta de regulação apresentada.

A pesquisa empírica realizada com agentes que foram afetados pela determinação de transferência das DIT demonstra que a percepção sobre a AIR é de que de fato, para esse processo, não foi utilizada corretamente, havendo a necessidade de se avaliar com dados concretos para a confirmação das premissas iniciais da ANEEL.

A mesma pesquisa demonstra, no entanto, que a ANEEL vem se utilizando da ferramenta de participação pública de modo mais efetivo, abrindo espaço para manifestação dos agentes. Em que pese, nesse ponto, a pesquisa demonstre divergência dos agentes no sentido de que a ANEEL não se demonstra aberta a novas ideias além das já colocadas, tal percepção pode ser explicada sob o ponto de vista da dualidade estabelecidas pelas transmissoras e distribuidoras.

Uma vez que participaram da pesquisa mais transmissoras do que distribuidoras e ainda que a maioria dessas empresas de transmissão de energia elétrica era contrária a proposta, o não acatamento das contribuições no sentido de cancelar a determinação de transferência pode ter causado insatisfação.

Mas, em contrapartida, a maioria das empresas demonstra que a aplicação do espaço de participação pública por meio da Audiência Pública possibilitou a aplicação de uma regulação razoável. Nesse ponto, importante observar ainda que a análise das contribuições realizadas pelos agentes possibilitou que a ANEEL evoluísse na proposta de regulação sobre a 
transferência das DIT, impedindo que fossem transferidos um grande volume de instalações que implicariam em indefinições sistêmicas, técnicas e financeiras, com a necessidade de se pagar uma grande quantia de indenizações, visto que as instalações em sua maioria não estavam totalmente amortizadas e depreciadas como previa a ANEEL, bem como a implantação e duplicação de estruturas, o que implicaria necessariamente em aumento de obras e tarifa para o consumidor final. 


\section{O ATUAL ESTÁGIO DA AIR NA ANEEL}

Como já avaliado, o processo de AIR na ANEEL foi iniciado pela Resolução Normativa $n^{\circ} 540 / 2013$.

A Resolução previa a realização de algumas etapas para a identificação de um problema regulatório, bem como o estudo das alternativas regulatórias para propositura da melhor alternativa.

A Resolução Normativa $n^{\circ} 540 / 2013$ no entanto, não previa a realização de audiência/consulta pública para aprimoramento e discussão das próprias alternativas discutidas na AIR.

Tal fator foi aprimorado por meio da publicação da Resolução Normativa no 798/2017, que priorizou o debate por meio da AIR e deixou mais claros os seus objetivos como instrumento de auxílio na tomada de decisão.

Assim, após a publicação da aludida Resolução Normativa, foi priorizada a participação pública, bem como a ativa participação dos agentes envolvidos na

\subsection{O CUMPRIMENTO DA RESOLUÇÃO NORMATIVA No 798/2017}

Como avaliado, a resolução Normativa $n^{\circ} 540 / 2013$ possuía algumas falhas, as quais foram identificadas pela própria ANEEL e puderam ser observadas na análise do processo de transferência das DIT.

Assim, durante a aplicação da Resolução 540/2013, a AIR era aplicado como mais um formulário a ser preenchido no processo regulatório, o que, por vezes, era sequer aplicado.

A presente etapa da investigação visa verificar se, de fato, após a implantação das melhorias propostas no processo de AIR pela Resolução Normativa nº 798/2017 estão sendo observadas pela ANEEL. 
Para a referida avaliação foram analisadas as audiências/consultas públicas ${ }^{22}$ realizadas no ano de 2019, todas relacionadas a implementação de novas regulações pela ANEEL. Por terem efeito concentrado em uma única empresa, foram excluídas da análise as audiências/consultas relacionadas a revisões tarifárias.

22 A partir de 30/09/2019 os processos de participação pública por meio de intercambio documental foram denominados Consulta Pública em razão da nomenclatura adotada pela Lei 13.848/2019. 


\begin{tabular}{|c|c|c|c|c|c|}
\hline $\begin{array}{l}\text { Audiência } \\
\text { Consulta } \\
\text { Pública }\end{array}$ & Tema & $\begin{array}{l}\text { AIR } \\
\text { Necessário? }\end{array}$ & $\begin{array}{lr}\text { AIR foi realizado e } \\
\text { colocado } & \text { em } \\
\text { discussão } & \\
\text { oportunizando } & \text { a } \\
\text { manifestação } & \text { dos } \\
\text { agentes? } & \end{array}$ & $\begin{array}{l}\text { AIR cumpriu } \\
\text { todas as etapas } \\
\text { previstas na } \\
\text { Resolução } \\
\text { Normativa } \quad \text { n }^{\circ} \\
\text { 798/2019? }\end{array}$ & $\begin{array}{l}\text { AIR se utilizou } \\
\text { de dados para } \\
\text { confirmar as } \\
\text { hipóteses } \\
\text { aventadas? }\end{array}$ \\
\hline $\begin{array}{l}\text { AP } \\
01 / 2019\end{array}$ & $\begin{array}{l}\text { Obter subsídios para a Análise de Impacto } \\
\text { Regulatório - AIR sobre o aprimoramento das } \\
\text { regras aplicáveis à micro e minigeração } \\
\text { distribuída (Resolução Normativa na } \\
\text { 482/2012). }\end{array}$ & $\begin{array}{l}\text { Sim. } \\
\text { Proposição de } \\
\text { nova regulação. }\end{array}$ & Sim & Sim & $\operatorname{sim}$ \\
\hline $\begin{array}{l}\text { AP } \\
02 / 2019\end{array}$ & $\begin{array}{l}\text { Obter subsídios para o aprimoramento das } \\
\text { Regras de Comercialização de Energia } \\
\text { Elétrica, em atendimento à Resolução } \\
\text { Normativa } n^{\circ} 822 / 2018 \text {. }\end{array}$ & $\begin{array}{l}\text { Não. Mera } \\
\text { adequação aos } \\
\text { termos legais }\end{array}$ & N/A & N/A & N/A \\
\hline $\begin{array}{l}\text { AP } \\
03 / 2019\end{array}$ & $\begin{array}{l}\text { Obter subsídios para o aprimoramento da } \\
\text { regulamentação de critérios e procedimentos } \\
\text { de cálculo dos investimentos em bens } \\
\text { reversíveis não amortizados ou não } \\
\text { depreciados de concessões de geração } \\
\text { prorrogadas ou não, nos termos da Lei no } \\
12.783 / 2013 \text {. }\end{array}$ & $\begin{array}{l}\text { Não. Mera } \\
\text { adequação aos } \\
\text { termos legais }\end{array}$ & N/A & N/A & N/A \\
\hline $\begin{array}{l}\text { AP } \\
05 / 2019\end{array}$ & $\begin{array}{l}\text { Obter subsídios para o aprimoramento da } \\
\text { proposta de alteração das Regras de } \\
\text { Comercialização de Energia Elétrica em } \\
\text { atendimento à Resolução Normativa } \mathrm{n}^{\circ} \\
817 / 2018 \text { e ao Despacho } \mathrm{n}^{\circ} 1.400 / 2018 .\end{array}$ & $\begin{array}{l}\text { Não. Mera } \\
\text { adequação aos } \\
\text { termos legais }\end{array}$ & N/A & N/A & N/A \\
\hline
\end{tabular}




\begin{tabular}{|c|c|c|c|c|c|}
\hline $\begin{array}{l}\text { Audiência } \\
\text { Consulta } \\
\text { Pública }\end{array}$ & Tema & $\begin{array}{l}\text { AIR } \\
\text { Necessário? }\end{array}$ & $\begin{array}{lr}\text { AIR foi realizado e } \\
\text { colocado } & \text { em } \\
\text { discussão } & \\
\text { oportunizando } & \text { a } \\
\text { manifestação } & \text { dos } \\
\text { agentes? } & \end{array}$ & \begin{tabular}{lr} 
AIR cumpriu & \multicolumn{2}{c}{ cump } \\
todas as & etapas \\
previstas ra & na \\
Resolução & \\
Normativa & n $^{\circ}$ \\
798/2019? &
\end{tabular} & $\begin{array}{lr}\text { AIR se utilizou } \\
\text { de dados para } \\
\text { confirmar as } \\
\text { hipóteses } \\
\text { aventadas? }\end{array}$ \\
\hline $\begin{array}{l}\text { AP } \\
07 / 2019\end{array}$ & $\begin{array}{l}\text { Obter subsídios para o aprimoramento da } \\
\text { minuta do Edital e respectivos Anexos do } \\
\text { Leilão } \mathrm{n}^{\circ} 1 / 2019 \text {, denominado Leilão para } \\
\text { Suprimento a Boa Vista e Localidades } \\
\text { Conectadas de } 2019 \text {, o qual se destina à } \\
\text { aquisição de energia e potência elétrica de } \\
\text { agente vendedor, por meio de soluções de } \\
\text { suprimento de quaisquer fontes, com início de } \\
\text { suprimento em } 28 \text { de junho de } 2021 \text {. }\end{array}$ & $\begin{array}{l}\text { Não. Mera } \\
\text { adequação aos } \\
\text { termos legais }\end{array}$ & N/A & N/A & N/A \\
\hline $\begin{array}{l}\text { AP } \\
08 / 2019\end{array}$ & $\begin{array}{l}\text { Revisão das faixas de acionamento e dos } \\
\text { adicionais das bandeiras tarifárias com } \\
\text { vigência a partir de maio de } 2019 \text {. }\end{array}$ & $\begin{array}{l}\text { Não. Mera } \\
\text { adequação aos } \\
\text { termos legais }\end{array}$ & N/A & N/A & N/A \\
\hline $\begin{array}{l}\text { AP } \\
12 / 2019\end{array}$ & $\begin{array}{l}\text { Obter subsídios para o aprimoramento da } \\
\text { minuta do Edital e respectivos Anexos do } \\
\text { Leilão no } 3 / 2019 \text {, o qual se destina à } \\
\text { contratação de energia elétrica proveniente de } \\
\text { novos empreendimentos de geração de energia } \\
\text { elétrica de fontes hidrelétrica, eólica, solar } \\
\text { fotovoltaica e termelétrica a biomassa. }\end{array}$ & $\begin{array}{l}\text { Não. Mera } \\
\text { adequação aos } \\
\text { termos legais }\end{array}$ & N/A & N/A & N/A \\
\hline
\end{tabular}




\begin{tabular}{|c|c|c|c|c|c|}
\hline $\begin{array}{l}\text { Audiência } \\
\text { Consulta } \\
\text { Pública }\end{array}$ & Tema & $\begin{array}{l}\text { AIR } \\
\text { Necessário? }\end{array}$ & $\begin{array}{lr}\text { AIR foi realizado e } \\
\text { colocado } & \text { em } \\
\text { discussão } & \\
\text { oportunizando } & \text { a } \\
\text { manifestação } & \text { dos } \\
\text { agentes? }\end{array}$ & $\begin{array}{l}\text { AIR cumpriu } \\
\text { todas as etapas } \\
\text { previstas na } \\
\text { Resolução } \\
\text { Normativa } \quad \text { no }^{\circ} \\
\text { 798/2019? }\end{array}$ & $\begin{array}{l}\text { AIR se utilizou } \\
\text { de dados para } \\
\text { confirmar as } \\
\text { hipóteses } \\
\text { aventadas? }\end{array}$ \\
\hline $\begin{array}{l}\text { AP } \\
13 / 2019\end{array}$ & $\begin{array}{l}\text { Obter subsídios para os aprimoramentos } \\
\text { normativos decorrentes do processo de } \\
\text { reavaliação da Resolução Normativa } \mathrm{n}^{\mathrm{o}} \\
673 / 2015 \text {, que estabelece os requisitos e } \\
\text { procedimentos para obtenção de outorga de } \\
\text { autorização para exploração de aproveitamento } \\
\text { de potencial hidráulico com características de } \\
\text { Pequena Central Hidrelétrica - PCH, e } \\
\text { respectiva Análise de Impacto Regulatório - } \\
\text { AIR. }\end{array}$ & $\begin{array}{l}\text { Sim, } \\
\text { propositura de } \\
\text { nova } \\
\text { metodologia }\end{array}$ & Sim & Sim & $\operatorname{sim}$ \\
\hline $\begin{array}{l}\text { AP } \\
15 / 2019\end{array}$ & $\begin{array}{l}\text { Obter subsídios para a regulamentação das } \\
\text { disposições do Decreto n } \mathrm{n}^{\circ} 9.597 / 2018 \text {, } \\
\text { relacionadas à implantação da infraestrutura de } \\
\text { energia elétrica nas situações de interesse } \\
\text { social. }\end{array}$ & $\begin{array}{l}\text { Não. Mera } \\
\text { adequação aos } \\
\text { termos legais }\end{array}$ & N/A & N/A & N/A \\
\hline
\end{tabular}




\begin{tabular}{|c|c|c|c|c|c|}
\hline $\begin{array}{l}\text { Audiência } \\
\text { Consulta } \\
\text { Pública }\end{array}$ & Tema & $\begin{array}{l}\text { AIR } \\
\text { Necessário? }\end{array}$ & $\begin{array}{lr}\text { AIR foi realizado e } \\
\text { colocado } & \text { em } \\
\text { discussão } & \\
\text { oportunizando } & \text { a } \\
\text { manifestação } & \text { dos } \\
\text { agentes? } & \end{array}$ & $\begin{array}{lr}\text { AIR cumpriu } \\
\text { todas as etapas } \\
\text { previstas } \\
\text { Resolução } \\
\text { Normativa } \\
\text { 798/2019? }\end{array}$ & $\begin{array}{lr}\text { AIR se utilizou } \\
\text { de dados para } \\
\text { confirmar as } \\
\text { hipóteses } \\
\text { aventadas? }\end{array}$ \\
\hline $\begin{array}{l}\text { AP } \\
19 / 2019\end{array}$ & $\begin{array}{l}\text { Obter subsídios para aprimoramento da } \\
\text { proposta de tratamento regulatório aos } \\
\text { despachos por patamar de usinas termelétricas. }\end{array}$ & $\begin{array}{l}\text { Sim, no entanto } \\
\text { AIR não foi } \\
\text { realizado }\end{array}$ & Não & Não & Não \\
\hline $\begin{array}{l}\text { AP } \\
22 / 2019\end{array}$ & $\begin{array}{l}\text { Obter subsídios para o aprimoramento da } \\
\text { metodologia de definição dos limites máximo } \\
\text { e mínimo do Preço de Liquidação das } \\
\text { Diferenças - PLD }\end{array}$ & $\begin{array}{l}\text { Sim, } \\
\text { propositura de } \\
\text { nova } \\
\text { metodologia }\end{array}$ & Sim & Sim & Sim \\
\hline $\begin{array}{l}\text { AP } \\
23 / 2019\end{array}$ & $\begin{array}{l}\text { Obter subsídios e informações adicionais para } \\
\text { aprimoramento da proposta de Edital do Leilão } \\
\text { de Transmissão } \text { no }^{\text {o }} 2 / 2019 \text {, destinado à } \\
\text { contratação de serviço público de transmissão } \\
\text { de energia elétrica, referente à construção, à } \\
\text { operação e à manutenção de linhas de } \\
\text { transmissão, subestações e demais instalações } \\
\text { integrantes da Rede Básica do Sistema } \\
\text { Interligado Nacional - SIN. }\end{array}$ & $\begin{array}{l}\text { Não. Mera } \\
\text { adequação aos } \\
\text { termos legais }\end{array}$ & $\mathrm{N} / \mathrm{A}$ & $\mathrm{N} / \mathrm{A}$ & $\mathrm{N} / \mathrm{A}$ \\
\hline $\begin{array}{l}\text { AP } \\
25 / 2019\end{array}$ & $\begin{array}{l}\text { Obter subsídios à proposta de aprimoramento } \\
\text { da regulamentação da Conta de Variação de } \\
\text { Valores de Itens da Parcela A - CVA, da } \\
\text { Sobrecontratação de Energia e Exposição ao } \\
\text { Mercado de Curto Prazo - MCP, dos Demais } \\
\text { Componentes Financeiros e das Regras de } \\
\text { Repasse dos Preços dos Contratos de Compra } \\
\text { de Energia. }\end{array}$ & $\begin{array}{l}\text { Sim, } \\
\text { propositura de } \\
\text { nova } \\
\text { metodologia }\end{array}$ & Sim & Sim & Sim \\
\hline
\end{tabular}




\begin{tabular}{|c|c|c|c|c|c|}
\hline $\begin{array}{l}\text { Audiência } \\
\text { Consulta } \\
\text { Pública }\end{array}$ & Tema & $\begin{array}{l}\text { AIR } \\
\text { Necessário? }\end{array}$ & $\begin{array}{lr}\text { AIR foi realizado e } \\
\text { colocado } & \text { em } \\
\text { discussão } & \\
\text { oportunizando } & \text { a } \\
\text { manifestação } & \text { dos } \\
\text { agentes? }\end{array}$ & $\begin{array}{lr}\text { AIR cumpriu } \\
\text { todas as etapas } \\
\text { previstas na } \\
\text { Resolução } \\
\text { Normativa } \quad \text { n }^{\circ} \\
\text { 798/2019? }\end{array}$ & $\begin{array}{l}\text { AIR se utilizou } \\
\text { de dados para } \\
\text { confirmar as } \\
\text { hipóteses } \\
\text { aventadas? }\end{array}$ \\
\hline $\begin{array}{l}\text { AP } \\
26 / 2019\end{array}$ & $\begin{array}{l}\text { Obter subsídios e informações adicionais para } \\
\text { o aprimoramento da proposta de revisão dos } \\
\text { requisitos do regime de operação das } \\
\text { instalações de transmissão e de geração de } \\
\text { energia elétrica estabelecidos nos } \\
\text { Procedimentos de Rede. }\end{array}$ & $\begin{array}{l}\text { Sim, } \\
\text { propositura de } \\
\text { nova } \\
\text { metodologia }\end{array}$ & Sim & Sim & sim \\
\hline $\begin{array}{l}\text { AP } \\
29 / 2019\end{array}$ & $\begin{array}{l}\text { Obter subsídios para o aprimoramento da } \\
\text { minuta do Edital e respectivos Anexos do } \\
\text { Leilão de Geração no 4/2019-ANEEL, } \\
\text { denominado Leilão "A-6" de 2019, destinado à } \\
\text { compra de energia elétrica proveniente de } \\
\text { novos empreendimentos de geração. }\end{array}$ & $\begin{array}{l}\text { Não. Mera } \\
\text { adequação aos } \\
\text { termos legais }\end{array}$ & N/A & N/A & N/A \\
\hline $\begin{array}{l}\text { AP } \\
32 / 2019\end{array}$ & $\begin{array}{l}\text { Obter subsídios para o aprimoramento da } \\
\text { proposta de alteração das Regras de } \\
\text { Comercialização sobre importação de energia } \\
\text { elétrica da Argentina e do Uruguai }\end{array}$ & $\begin{array}{l}\text { Não. Mera } \\
\text { adequação aos } \\
\text { termos legais }\end{array}$ & N/A & N/A & N/A \\
\hline
\end{tabular}




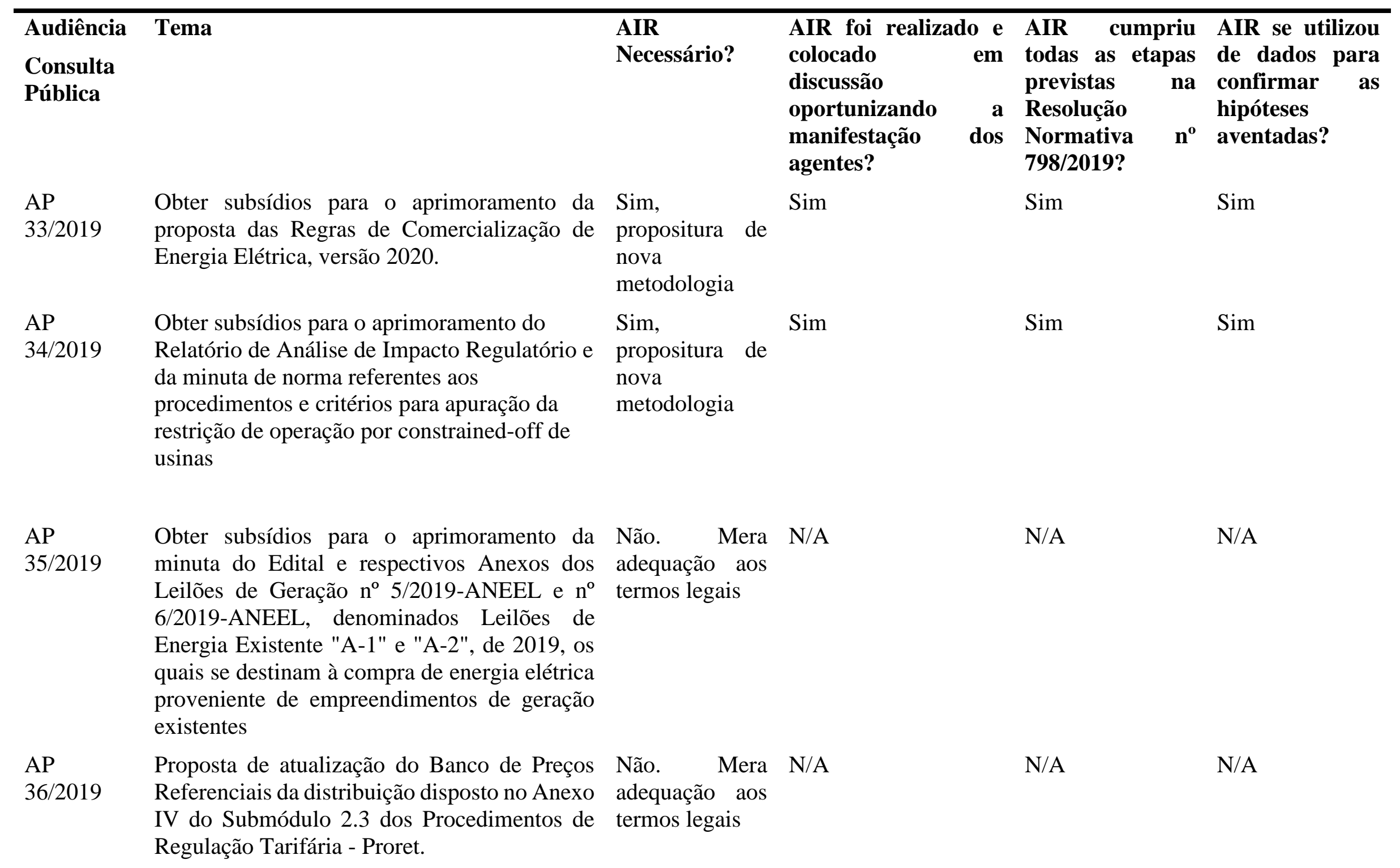




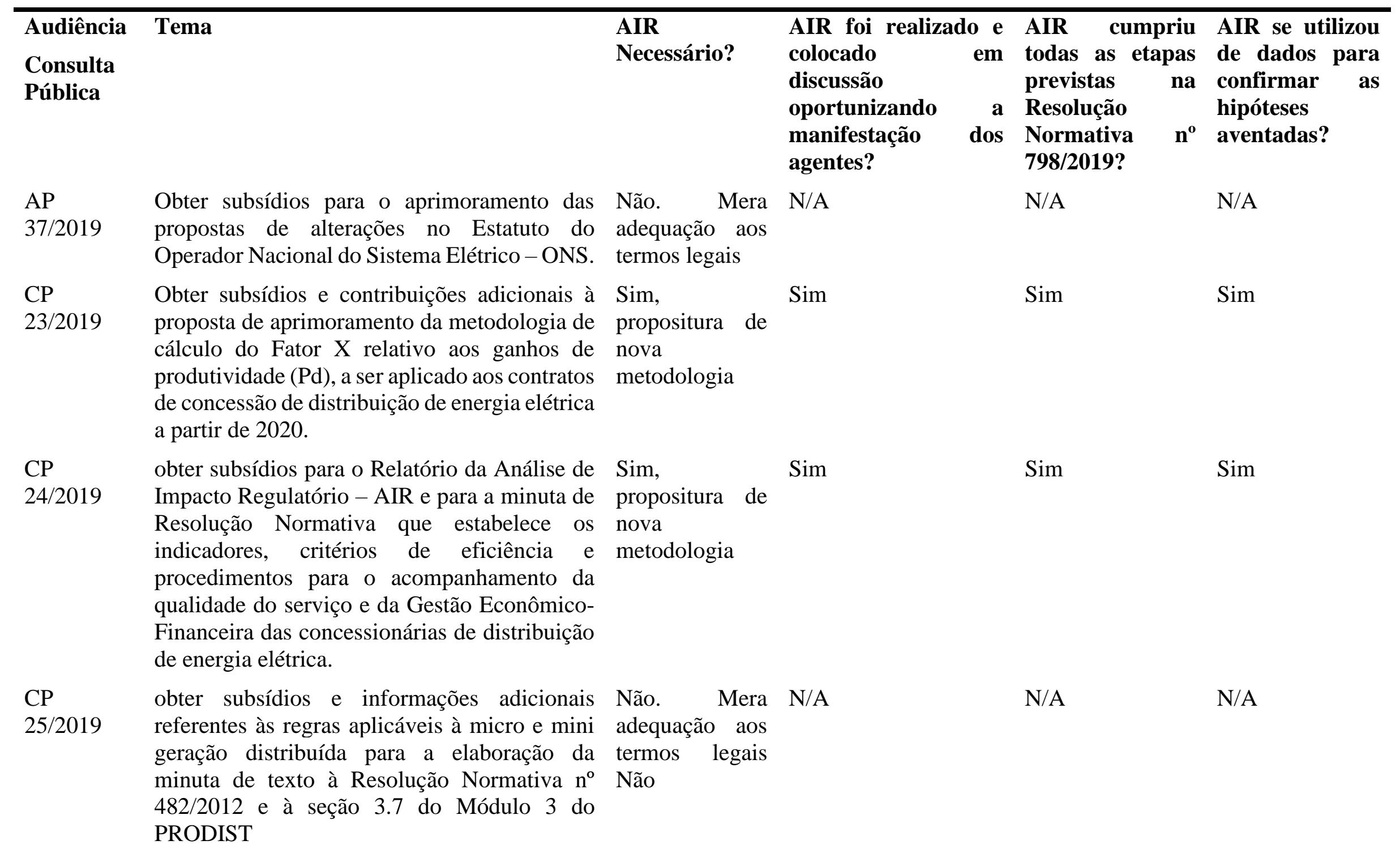




\begin{tabular}{|c|c|c|c|c|c|}
\hline $\begin{array}{l}\text { Audiência } \\
\text { Consulta } \\
\text { Pública }\end{array}$ & Tema & $\begin{array}{l}\text { AIR } \\
\text { Necessário? }\end{array}$ & $\begin{array}{lr}\text { AIR foi realizado e } \\
\text { colocado } & \text { em } \\
\text { discussão } & \\
\text { oportunizando } & \text { a } \\
\text { manifestação } & \text { dos } \\
\text { agentes? }\end{array}$ & $\begin{array}{l}\text { AIR cumpriu } \\
\text { todas as etapas } \\
\text { previstas na } \\
\text { Resolução } \\
\text { Normativa } \\
\text { 798/2019? }\end{array}$ & $\begin{array}{l}\text { AIR se utilizou } \\
\text { de dados para } \\
\text { confirmar as } \\
\text { hipóteses } \\
\text { aventadas? }\end{array}$ \\
\hline $\begin{array}{l}\text { CP } \\
26 / 2019\end{array}$ & $\begin{array}{l}\text { obter subsídios para definição de metodologia } \\
\text { de cálculo e atualização da taxa regulatória de } \\
\text { remuneração do capital. }\end{array}$ & $\begin{array}{l}\text { Sim, } \\
\text { propositura de } \\
\text { nova } \\
\text { metodologia }\end{array}$ & Sim & Sim & Sim \\
\hline $\begin{array}{l}\text { CP } \\
27 / 2019\end{array}$ & $\begin{array}{llllr}\text { Obter subsídios para normatizar } & \text { o } \\
\text { aprimoramento do mecanismo de Bandeiras } \\
\text { Tarifárias, com vistas a suprimir de } & \text { seus } \\
\text { critérios de cálculo o } & \text { o sistema } & \text { de } \\
\text { arredondamento. } & & & \end{array}$ & $\begin{array}{l}\text { Não. Mera } \\
\text { adequação aos } \\
\text { termos legais }\end{array}$ & N/A & N/A & N/A \\
\hline $\begin{array}{l}\text { CP } \\
33 / 2019\end{array}$ & $\begin{array}{l}\text { Obter subsídios para o aprimoramento da } \\
\text { regulamentação que trata das Exposições } \\
\text { Financeiras de Energia Secundária. }\end{array}$ & $\begin{array}{l}\text { Sim, } \\
\text { propositura de } \\
\text { nova } \\
\text { metodologia }\end{array}$ & Sim & Sim & Sim \\
\hline
\end{tabular}




\begin{tabular}{|c|c|c|c|c|c|}
\hline $\begin{array}{l}\text { Audiência } \\
\text { Consulta } \\
\text { Pública }\end{array}$ & Tema & $\begin{array}{l}\text { AIR } \\
\text { Necessário? }\end{array}$ & $\begin{array}{lr}\begin{array}{l}\text { AIR foi realizado e } \\
\text { colocado }\end{array} & \text { em } \\
\text { discussão } & \\
\text { oportunizando } & \text { a } \\
\text { manifestação } & \text { dos } \\
\text { agentes? } & \end{array}$ & $\begin{array}{lr}\text { AIR cumpriu } \\
\text { todas as } & \text { etapas } \\
\text { previstas } & \text { na } \\
\text { Resolução } & \\
\text { Normativa } & \mathbf{n}^{\circ} \\
\text { 798/2019? } & \end{array}$ & $\begin{array}{lr}\text { AIR se utilizou } \\
\text { de dados para } \\
\text { confirmar as } \\
\text { hipóteses } \\
\text { aventadas? }\end{array}$ \\
\hline $\begin{array}{l}\text { CP } \\
34 / 2019\end{array}$ & $\begin{array}{l}\text { Obter subsídios e informações adicionais para } \\
\text { o aprimoramento das Regras de } \\
\text { Comercialização de Energia Elétrica, versão } \\
2020 \text {. }\end{array}$ & $\begin{array}{l}\text { Não. Mera } \\
\text { adequação aos } \\
\text { termos legais }\end{array}$ & N/A & N/A & N/A \\
\hline $\begin{array}{l}\text { CP } \\
36 / 2019\end{array}$ & $\begin{array}{l}\text { Obter subsídios para a revisão do item 4.1.1.1 } \\
\text { (a)(3) do Submódulo } 13.2 \text { dos Procedimentos } \\
\text { de Rede. }\end{array}$ & $\begin{array}{l}\text { Não. Mera } \\
\text { adequação aos } \\
\text { termos legais }\end{array}$ & N/A & N/A & N/A \\
\hline
\end{tabular}

Fonte: Audiências e Consultas Públicas realizadas pela ANEEL no ano de 2019. 
Da avaliação realizada, notou-se que das 35 audiências e consultas públicas realizadas no ano de 2019, apenas uma cometeu desvio de conduta relacionado a Resolução Normativa ${ }^{\circ}$ $798 / 2017$.

Todas as demais cumpriram com o rito estabelecido na Resolução Normativa $\mathrm{n}^{\circ}$ 798/2017, estabelecendo ampla participação popular, com a análise de dados relacionados as hipóteses aventadas pela Agência.

Observa-se dessa forma que com a implantação da Resolução Normativa n ${ }^{\circ}$ 798/2017 a participação pública tornou-se parte intrínseca da AIR, sem a qual a aplicação do instrumento não se torna possível.

\subsection{CONCLUSÃO PARCIAL}

A implantação das melhorias trazidas pela Resolução Normativa nº 798/2017 pretendeu tornar mais efetivo e eficaz o processo de AIR No âmbito da ANEEL.

Da análise das audiências/consultas públicas realizadas no ano de 2019, observa-se que 34 delas (das 35 analisadas) seguiram todo o rito estabelecido pela Resolução, sendo que o próprio relatório de AIR foi objeto das Audiências/Consultas Públicas.

O novo modelo prioriza mais a participação popular na tomada de decisão e a escolha pela melhor opção regulatório. Das AIR apresentadas e analisadas também se observada um maior rigor da ANEEL na análise e obtenção de dados, de forma a evitar que o processo se torne apenas mais uma parte burocrática do processo de tomada de decisão.

Assim, com as modificações propostas, o processo de AIR caminha para se tornar mais eficaz e efetivo. 


\section{CONCLUSÃO}

A AIR como definição é uma ferramenta que auxilia órgãos governamentais na tomada de decisões. Desse modo, identificado um problema regulatório, a AIR auxilia na identificação de cenários possíveis de atuação, servindo como base para a tomada de decisão.

Em que pese seja uma ferramenta bastante popular, amplamente adotada pela OECD e por seus países membros desde 1997, teve sua aplicação iniciada no Brasil apenas em 2007, promovida pelas ações do PRO_REG.

No âmbito regulatório, tornou-se de obrigatória presença no processo de tomada de decisão das Agências Reguladoras apenas em 2019, em razão das disposições contidas na Lei 13.848 .

Embora tenha se tornado obrigatória em 2019, na ANEEL é aplicada desde 2013. Implantada pela Resolução Normativa n ${ }^{\circ} 540 / 2013$, foi aprimorada pela Resolução Normativa $n^{\circ} 798 / 2017$ e hoje prestigia a participação popular, que se tornou essencial e intrínseca ao processo e a análise de dados que confirmem as hipóteses aventadas pela Agência.

Percebe-se, com o passar dos anos, um verdadeiro amadurecimento das AIR realizadas pela ANEEL, que atualmente contam com mais elementos e dados completos e confiáveis que permitem uma análise apurada do problema posto.

Mas, resta saber se a aplicação dos processos de AIR no âmbito da ANEEL vem de fato contribuindo para o processo de tomada de decisão no âmbito regulatório, fornecendo ferramentas para a melhoria contínua da qualidade e governança regulatória na Agência.

Diante dessa hipótese e pergunta, o principal objetivo da presente investigação foi o de responder a quatro perguntar principais, listadas abaixo, e que refletem um objetivo central maior, que é o de analisar a eficácia, adequação e efetividade dos processos de AIR no âmbito da ANEEL. 
(i) O modelo de AIR implementada pela Resolução Normativa $n^{\circ}$ 540/2013 aplicado ao caso de transferência das DIT foi o suficiente para identificar os problemas advindos da regulação sobre o tema?

(ii) O modelo implementado pela Resolução Normativa $n^{\circ} 798 / 2017$ é o ideal para a Agência?

(iii)O modelo implementado pela Resolução Normativa nº 798/2017 cumpriu o papel ao qual se propôs?

(iv)A participação pública prevista é eficiente?

Para tanto, foi definido um caso base, cujo histórico de atuação, AIR e mecanismos de participação popular foram cuidadosamente avaliados: o caso da transferência das DIT.

Posteriormente, verificadas as falhas do processo, em especial porque o caso avaliado se deu na vigência da Resolução Normativa $n^{\circ}$ 540/2013, foram avaliados os processos de AIR efetuados no ano de 2019, já na vigência da Resolução Normativa nº 798/2017.

Considerando o histórico de implantação da AIR na ANEEL, foi avaliado processo de implantação de importante Resolução Normativa, que teve por objetivo principal a determinação de transferência das DIT das transmissoras para as distribuidoras e que resultou em conflito de interesses entre as concessionárias.

Em especial sobre o estudo de caso relacionado a transferência das DIT, conclui-se que o processo de AIR realizado à época não se demonstrou efetivo e eficaz o suficiente, visto que adotou premissas genéricas, sem a comprovação de dados, que foram encaradas como verdades absolutas que justificariam a transferência total das DIT das transmissoras para as distribuidoras.

A correção do problema demonstrado pela tentativa de regulação só foi possível graças a aplicação adequada do processo de participação popular, que trouxe a luz questões que deveriam ter sido objeto do próprio AIR.

Ou seja, não há como afirmar que o modelo de AIR previsto na Resolução Normativa $n^{\circ} 540 / 2013$ não era eficaz e eficiente o suficiente no sentido de ser inválido como ferramenta para a tomada de decisão, visto que desde 2013 a regulação da ANEEL já previa a necessidade 
de aprofundamento dos estudos e dados relacionados aos problemas regulatórios identificados. No entanto, o que se percebe, fato esse constatado pelo própria ANEEL quando da revisão da norma, é que não apenas a Resolução Normativa ${ }^{\circ}$ 540/2013 necessitava de aprimoramentos, como foi necessário um tempo para que o conceito de AIR e sua utilidade fosse internalizada pela Agência.

Isso porque, no estudo de caso o que se verificou é que, em que pese os dados que deveriam ter sido analisados fossem complexos, a ANEEL, como Agência Reguladora do setor tinha acesso a tais dados, faltando apenas a sua análise aprofundada.

No entanto, muito embora o acesso aos dados fosse possível, a ANEEL optou por realizar uma AIR com base em premissas não comprovadas por tais dados, o que fragilizou a análise realizada.

Assim, a falha não se encontrava propriamente no modelo utilizado, mas sim na avaliação de dados realizada pela Agência.

Por outro lado, em que pese a AIR tenha sido falha nesse sentido, chegando a conclusão de que uma regulamentação era possível de ser aplicada quando em verdade, não o era, percebeu-se uma boa condução do processo de participação pública.

Intrínseca a AIR, a participação pública no caso das DIT foi fundamental para apresentar para a ANEEL questões essenciais que impossibilitariam a implantação da Resolução como pretendido inicialmente pela Agência.

Inclusive, tais afirmativas foram confirmadas pela pesquisa realizada com agentes afetados pela transferência das DIT. Nesse contexto, o que se percebe é que, em que pese a AIR realizada tenha seguido as premissas da Resolução Normativa $\mathrm{n}^{\circ}$ 540/2013 vigente a época, deixou de aprofundar os estudos necessários que levariam as conclusões indicadas por meio das fases de Audiência Pública.

Assim, o que se conclui é que, em que esse à época a ferramenta de AIR estivesse disponível, não foi corretamente utilizada, pela falta de análise de dados concretos sobre as premissas inicialmente levantadas. 
A partir de então, a primeira pergunta da pesquisa pode ser respondida. Nesse contexto, chega-se à conclusão de que o maior problema relacionado ao caso das DIT não estava propriamente no modelo proposto pela Resolução Normativa n ${ }^{\circ}$ 540/2013, mas sim na análise de dados realizada pela própria Agência.

O modelo, portanto, em que pese carecesse de alguns aprimoramentos, especialmente os relacionados a participação popular, teria sido capaz de identificar os pontos e problemas relevantes da implantação da regulação, visto que determinava a descrição do problema regulatório, das possibilidades de intervenção, bem como dos problemas atrelados a cada possibilidade. No entanto, não foram bem utilizados pela ANEEL, visto que os dados relacionados ao problema regulatório não foram analisados.

Além da análise do modelo apresentado pela Resolução Normativa $n^{\circ}$ 540/2013, foi avaliado o modelo proposto pela Resolução Normativa $n^{\circ} 798 / 2017$, que se coaduna com as recomendações da Casa Civil e privilegia a participação pública.

Da análise dos processos de AIR do ano de 2019, verificou-se maior rigor na avaliação de possibilidades de solução de um problema regulatório, bem como na análise e coleta de dados relacionados ao tema a ser tratado. Todos os AIR avaliados se pautaram em dados concretos e não apenas em afirmativas sem a devida comprovação.

Desse modo, uma vez que modelo existente na ANEEL é alinhado com a recomendação da Casa Civil, bem como da OECD, não há outra conclusão possível que não de afirmar que o modelo seria o ideal para a Agência, especialmente porque possibilitou a maior participação dos agentes já na fase de discussão das alternativas regulatórias.

Assim, atualmente o modelo utilizado pela ANEEL atribui grande valor a participação popular, o que é recomendado nos modelos da CASA CIVIL e da OECD.

Não há, portanto, como afirmar que o modelo utilizado atualmente não cumpre o papel para o qual se propôs, qual seja, o de ser uma ferramenta de auxílio na tomada de decisões, sendo que, em verdade, o que influencia de fato na qualidade da AIR realizada reside na qualidade e consistência dos dados analisados. 
Por fim, resta avaliar se a participação pública prevista nos processos de tomada de decisão da ANEEL sã eficientes.

Nesse contexto e como restou amplamente demonstrado que o processo decisório da ANEEL envolve diversas etapas de participação social, desde a criação da Agência. Ou seja, a participação dos agentes na tomada de decisão regulatória sempre se demonstrou como um valor da ANEEL.

O estudo de caso demonstrou que, em eu pese diversas das contribuições realizadas pelos agentes não tenham sido acatadas, a ANEEL se utilizou de dados fundamentais que possibilitaram a alteração do regulamento proposto. Assim, embora a pesquisa empírica tenha demonstrado que ainda há espaço para melhorar o relacionamento e pontos de discussão entre ANEEL e agentes, não há como afirmar que o processo de participação social não cumpre o seu papel de estabelecer um diálogo entre regulador e regulados e permitir a troca de informações.

\subsection{POSSÍVEIS TRABALHOS FUTUROS}

De modo da dar continuidade ao tema objeto da investigação, sugere-se, para trabalhos futuros, os seguintes temas de pesquisa:

(i) A ampliação da participação pública com a aplicação de ferramentas virtuais.

(ii) Controle e qualidade dos dados utilizados na Análise de Impacto Regulatório.

(iii) Avaliação das ferramentas de controle e qualidade regulatória no Brasil.

(iv) Percepção da população sobre a democracia participativa aplicada na Agência Nacional de Energia Elétrica. 


\section{REFERÊNCIAS BIBLIOGRÁFICAS}

AGÊNCIA NACIONAL DE ÁGUAS. Resolução 76 de 2019. Aprova o Regimento Interno e o Quadro Demonstrativo de Cargos em Comissão da Agência Nacional de Águas - ANA. 2019.

AGÊNCIA NACIONAL DE ENERGIA ELÉTRICA. Audiência Pública nº 41 de 2015. Obter subsídios para a análise da proposta de transferência das Demais Instalações de Transmissão DIT para as distribuidoras. 2015.

AGÊNCIA NACIONAL DE ENERGIA ELÉTRICA. Audiência Pública no 44 de 2017. Obter subsídios para o aprimoramento da Norma de Organização $n^{\circ}$ 40/2013, aprovada pela Resolução Normativa $\mathrm{n}^{\circ}$ 540/2013, que dispõe sobre realização de Análise de Impacto Regulatório - AIR no âmbito da ANEEL. 2017.

AGÊNCIA NACIONAL DE ENERGIA ELÉTRICA. Audiência Pública nº 64 de 2012. Obter subsídios à proposta de resolução normativa que dispõe sobre a realização de Análise de Impacto Regulatório - AIR na ANEEL. 2012.

AGÊNCIA NACIONAL DE ENERGIA ELÉTRICA. Audiência Pública nº 001 de 2019. Relatório de Análise de Impacto regulatório Revisão das regras aplicáveis à micro e minigeração distribuída - Resolução Normativa n $\mathrm{n}^{\circ}$ 482/2012. Relatório de Análise de Impacto Regulatório nº 0004/2018-SRD/SCG/SMA/ANEEL. 2019.

AGÊNCIA NACIONAL DE ENERGIA ELÉTRICA. Audiência Pública no 14 de 2019. Análise de Impacto Regulatório - AIR da aplicação da Resolução Normativa n ${ }^{\circ} 709$, de 5 de abril de 2016. Relatório de Análise de Impacto Regulatório n¹/2019-SRT/ANEEL Anexo da Nota Técnica nº 10/2019-SRT/ANEEL. 2019.

AGÊNCIA NACIONAL DE ENERGIA ELÉTRICA. Audiência Pública 22 de 2019. Limites mínimo e máximo do Preço de Liquidação das Diferenças - PLD. Relatório de Análise de Impacto Regulatório nº 4/2019-SRM-SRG/ ANEEL Anexo da Nota Técnica nº 70/2019-SRMSRG/ANEEL. 2019.

AGÊNCIA NACIONAL DE ENERGIA ELÉTRICA. Audiência Pública 25 de 2019. Preço Médio dos Contratos de Compra de energia para cálculo de ajuste de sobrecontratação. Relatório de Análise de Impacto Regulatório nº 01/2019-SGT/ANEEL Anexo da Nota Técnica n 73/2019-SGT/ANEEL. 2019.

AGÊNCIA NACIONAL DE ENERGIA ELÉTRICA. Audiência Pública 26 de 2019. Obter subsídios e informações adicionais para o aprimoramento da proposta de revisão dos requisitos do regime de operação das instalações de transmissão e de geração de energia elétrica estabelecidos nos Procedimentos de Rede. Relatório de Análise de Impacto Regulatório $\mathrm{n}^{\circ}$ 3/2019-SRT/SRG/SFE/SFG/ANEEL. 2019.

AGÊNCIA NACIONAL DE ENERGIA ELÉTRICA. Audiência Pública 33 de 2019. Mecanismos de Venda de Excedentes (MVE) Múltiplos lances para um mesmo produto, critério de desempate e novo produto. Relatório de Análise de Impacto Regulatório n ${ }^{\circ}$ N $^{\circ} 7 / 2019.2019$. 
AGÊNCIA NACIONAL DE ENERGIA ELÉTRICA. Audiência Pública no 34 de 2019. Tratamento regulatório à situação de Constrained-off de usinas eólicas Relatório de Análise de Impacto Regulatório $n^{\circ}$ 001/2019-SRG/ANEEL Anexo da Nota Técnica no 147/2018SRG/ANEEL. 2019.

AGÊNCIA NACIONAL DE ENERGIA ELÉTRICA. Consulta Pública no 23 de 2019 Revisão Metodológica - Fator X Relatório de Análise de Impacto Regulatório nº 8/2019-SRM/ANEEL Anexo da Nota Técnica nº 94/2019-SRM/ANEEL. 2019.

AGÊNCIA NACIONAL DE ENERGIA ELÉTRICA. Consulta Pública $n^{\circ} 24$ de 2019: Regulamentação que estabelece os Critérios de Eficiência com relação à continuidade do fornecimento e à Gestão Econômico-Financeira das concessões de serviço público de distribuição de energia elétrica e procedimentos para acompanhamento Relatório de Análise de Impacto Regulatório no 0002/2019-/ANEEL Anexo da Nota Técnica nº 0068/2019/ANEEL Superintendência de Regulação dos Serviços de Distribuição - SRD Superintendência de Regulação Econômica e Estudos de Mercado - SRM Superintendência de Fiscalização dos Serviços de Eletricidade - SFE. 2019.

AGÊNCIA NACIONAL DE ENERGIA ELÉTRICA. Consulta Pública no 26 de 2019: Taxa Regulatória de Remuneração do Capital Relatório de Análise de Impacto Regulatório $\mathrm{n}^{\circ}$ 9/2019-SRM/ANEEL Anexo da Nota Técnica no 113-2019-SRM/. Superintendência de Fiscalização Econômica e Financeira - SFF Brasília, 02/09/2019 - Versão Pré-Participação Pública. 2019.

AGÊNCIA NACIONAL DE ENERGIA ELÉTRICA. Consulta Pública no 33 de 2019. Obter subsídios para o aprimoramento da regulamentação que trata das Exposições Financeiras de Energia Secundária. Relatório de Análise de Impacto Regulatório nº 003/2019-SRG/ANEEL . Agência Nacional de Energia Elétrica, 2019.

AGÊNCIA NACIONAL DE ENERGIA ELÉTRICA. Nota Técnica no 0032/2015SRD/ANEEL, de 02/06/2015. 2015.

AGÊNCIA NACIONAL DE ENERGIA ELÉTRICA Nota Técnica n ${ }^{\circ}$ 0170/2016SRD/SRT/SCT/SRM/SGT/SFF/ANEEL, de 16/12/2016.2016.

AGÊNCIA NACIONAL DE ENERGIA ELÉTRICA Nota Técnica n ${ }^{\circ}$ 0048/2016SRD/SRT/SCT/SRM/SGT/SFF/ANEEL. 2016.

AGÊNCIA NACIONAL DE ENERGIA ELÉTRICA Nota Técnica 009/2017-ASD/ANEEL de 30/06/2017. 2017.

AGÊNCIA NACIONAL DE ENERGIA ELÉTRICA. Resolução 166 de 2000. Atualiza a composição da rede básica do sistema elétrico interligado, suas conexões e as respectivas empresas usuárias das instalações. 2000.

AGÊNCIA NACIONAL DE ENERGIA ELÉTRICA. Resolução nº 67 de 2004. Estabelece os critérios para composição da rede básica do Sistema Interligado Nacional - SIN, e altera os arts. 18 e 21 da Resolução ANEEL 281 de 01.10.1999; Revoga a Resolução 433 de 10.11.2000. 2004. 
AGÊNCIA NACIONAL DE ENERGIA ELÉTRICA. Resolução nº 68 de 2004. Estabelece os procedimentos para a implementação de reforços nas demais instalações de transmissão, não integrantes da rede básica, e para a expansão das instalações de transmissão de âmbito próprio, de interesse sistêmico, das concessionárias ou permissionárias de distribuição de energia elétrica; Revoga a Resolução 489 de 29.08.2002. 2004.

AGÊNCIA NACIONAL DE ENERGIA ELÉTRICA. Resolução Normativa no 273 de 2007. Aprova a revisão da Norma de Organização ANEEL 001, que dispõe sobre os procedimentos para o funcionamento, a ordem dos trabalhos e os processos da Diretoria, nas matérias relativas à regulação e à fiscalização dos serviços e instalações de energia elétrica; e revoga a Resolução ANEEL 233 de 14.07.1998. 2007.

AGÊNCIA NACIONAL DE ENERGIA ELÉTRICA. Resolução Normativa 443 DE 2011. Estabelece a distinção entre melhorias e reforços em instalações de transmissão sob responsabilidade de concessionária de transmissão; inclui o parág. $3^{\circ}$, no art. $4^{\circ}$-B da Resolução Normativa ANEEL 068 de 08.06.2004; altera a ementa, o art. $1^{\circ}$, os parág. $2^{\circ}, 3^{\circ}$ e $4^{\circ}$ do art. $8^{\circ}$ da Resolução Normativa ANEEL 265 de 10.06.2003; bem como revoga a Resolução Normativa ANEEL 158 de 23.05.2005. 2011.

AGÊNCIA NACIONAL DE ENERGIA ELÉTRICA. Resolução Normativa no 540 de 2013. Aprova a Norma de Organização ANEEL 040, que dispõe sobre realização de análise de impacto regulatório - AIR, no âmbito da Agência. 2013.

AGÊNCIA NACIONAL DE ENERGIA ELÉTRICA. Resolução Normativa nº 758 de 2017. Estabelece as condições gerais para a incorporação das Demais Instalações de Transmissão DIT listadas no Anexo ao Ativo Imobilizado pelas concessionárias do serviço público de distribuição de energia elétrica. 2017.

AGÊNCIA NACIONAL DE ENERGIA ELÉTRICA. Resolução Normativa no 798 de 2017. Aprova a revisão da Norma de Organização ANEEL 040, que dispõe sobre a realização de Análise de Impacto Regulatório - AIR no âmbito da Agência; bem como revoga a Resolução Normativa ANEEL 540, de 12.03.2013 e o seu Anexo. 2017.

AGÊNCIA NACIONAL DE TELECOMUNICAÇÕES. Resolução 927 de 2015. Aprova o processo de regulamentação no âmbito da Agência. 2015

AGÊNCIA NACIONAL DE TELECOMUNICAÇÕES. Resolução 612 de 2013. Aprova o Regimento Interno da Anate. 2013.

AGÊNCIA NACIONAL DE TELECOMUNICAÇÕES. Guia de Boas Práticas regulatórias.

2018. Disponível em

https://antigo.anatel.gov.br/institucional/index.php?option=com_anexarlink\&hash=de50d93e0 c8e5cdc86274de5b3f5faae \&name=MANUAL\%20DE\%20BOAS\%20PR\%C3\%81TICAS\%2 0REGULAT\%C3\%93RIAS.pdf. Acesso em 22 de outubro de 2020.

AGÊNCIA NACIONAL DE TRANSPORTES TERRESTRES. Manual de Análise de Impacto Regulatório (AIR) e de Avaliação de Resultado Regulatório (ARR). Disponível em : http://governanca.antt.gov.br/AgendaRegulatoria/SiteAssets/Paginas/AIR/Manual\%20de\%20 AIR\%20e\%20ARR_2020.pdf consulta em 12 de dezembro de 2020. 
AGÊNCIA NACIONAL DE TRANSPORTE AQUAVIÁRIOS. Audiência Pública nº 05/2020. Disponível em: http://portal.antaq.gov.br/index.php/audiencia-publica-no-05-2020-antaq/. Acesso em 17 de dez. de 2020.

AGÊNCIA NACIONAL DE VIGILÂNCIA SANITÁRIA. Portaria 422 de 2008. Institui o Programa de Melhoria do Processo de Regulamentação no âmbito da Agência Nacional de Vigilância Sanitária e dá outras providências. 2008. Disponível em : http://www.lex.com.br/doc_1257347_PORTARIA_N_422_DE_16_DE_ABRIL_DE_2008.as px Acesso em 03 de nov. de 2020.

AGÊNCIA NACIONAL DE VIGILÂNCIA SANITÁRIA. Boas Práticas Regulatórias. 2008. Disponível em: http://antigo.anvisa.gov.br/documents/33880/2125963/Guia+para+o+Programa+de+Melhoria +do+Processo+de+Regulamenta\%C3\%A7\%C3\%A3o+da+Anvisa/c6d46467-74d4-4b39$\underline{89 \mathrm{bd}-\mathrm{c} 04493401 \mathrm{c} 73}$. Acesso em 1 de outubro de 2018.

AGÊNCIA NACIONAL DO PETRÓLEO, GÁS NATURAL E BIOCOMBUSTÍVEIS. Portaria nº 265 de 2020. Estabelece o Regimento Interno da Agência Nacional do Petróleo, Gás Natural e Biocombustíveis - ANP. 2020. Disponível em https://atosoficiais.com.br/lei/regimento-interno-anp-anp?origin=instituicao. Acesso em $01 \mathrm{de}$ nov. de 2020.

ARAUJO FONSECA Marcus Vinícius; SOUZA SILVA Danielle Assafin Vieira. Monitoramento para avaliação do desempenho regulatório. Instituto Nacional de Metrologia, Qualidade e Tecnologia Instituto Nacional de Metrologia, Qualidade e Tecnologia (Inmetro). Universidade Federal do Rio de Janeiro (UFRJ) Revista de Administração Pública — Rio de Janeiro 49(2):447-472, mar./abr. 2015.

BERMANN, Célio. Os limites dos aproveitamentos energéticos para fins elétricos: uma analise politica da questão energética e de suas repercussões socioambientais no Brasil. 1991. 309 f. Tese (doutorado) - Universidade Estadual de Campinas, Faculdade de Engenharia Mecânica, Campinas, SP. Disponível em: http://www.repositorio.unicamp.br/handle/REPOSIP/263869. Acesso em: 12 de dez. de 2019.

BRASIL. Câmara dos Deputados da República Federativa do Brasil. Projeto de Lei 1.539 de 2015. Estabelece a obrigatoriedade de realização de Análise de Impacto Regulatório - AIR pelas Agências Reguladoras no âmbito da Administração Federal. 2015.

BRASIL. Constituição (1934) Constituição da República Federativa do Brasil. Brasília, DF. 1934.

BRASIL. Constituição (1946) Constituição da República Federativa do Brasil. Brasília, DF. 1946.

BRASIL. Constituição (1988). Constituição da República Federativa do Brasil. Brasília, DF: Senado, 1988.

BRASIL. Decreto 24.643 de 1934. Decreta o Código de Águas. 1934.

BRASIL. Decreto 41.019 de 1957. Regulamenta os serviços de energia elétrica.1957. 
BRASIL. Decreto $n^{\circ} 2.335$ de 1998. Constitui a Agência Nacional de Energia Elétrica ANEEL, autarquia sob regime especial, aprova sua Estrutura Regimental e o Quadro Demonstrativo dos Cargos em Comissão e Funções de Confiança e dá outras providências.1998.

BRASIL. Decreto 2.655 de 1998. Regulamenta o Mercado Atacadista de Energia Elétrica, define as regras de organização do Operador Nacional do Sistema Elétrico, de que trata a Lei nº 9.648, de 27 de maio de 1998, e dá outras providências. 1998.

BRASIL. Decreto 4.176 de 2002. Estabelece normas e diretrizes para elaboração, redação, alteração, consolidação e o encaminhamento ao presidente da República de projetos de atos normativos de competência dos órgãos executivos federais. 2002.

BRASIL. Decreto 6.062 de 2007: Programa de Fortalecimento da Capacidade Institucional para Gestão em Regulação (PRO-REG). 2007.

BRASIL. Decreto 10.411 de 2020. Regulamenta a análise de impacto regulatório, de que tratam o art. $5^{\circ}$ da Lei $n^{\circ} 13.874$, de 20 de setembro de 2019 , e o art. $6^{\circ}$ da Lei $n^{\circ} 13.848$, de 25 de junho de 2019. 2020.

BRASIL. Lei 8.031 de 1990. Cria o Programa Nacional de Desestatização e dá outras providências. 1990.

BRASIL. Lei 8.987 de 1995. Dispõe sobre o regime de concessão e permissão da prestação de serviços públicos previsto no art. 175 da Constituição Federal, e dá outras providências.1995.

BRASIL. Lei 9.074 de 1995. Estabelece normas para outorga e prorrogações das concessões e permissões de serviços públicos e dá outras providências.1995.

BRASIL. Lei 9.427 de 1996. Institui a Agência Nacional de Energia Elétrica - ANEEL, disciplina o regime das concessões de serviços públicos de energia elétrica e dá outras providências. 1996.

BRASIL. Lei 9.648 de 1998.Altera dispositivos das Leis no 3.890-A, de 25 de abril de 1961, n⿳0 8.666, de 21 de junho de 1993, no 8.987, de 13 de fevereiro de 1995, no 9.074, de 7 de julho de 1995, no 9.427, de 26 de dezembro de 1996, e autoriza o Poder Executivo a promover a reestruturação da Centrais Elétricas Brasileiras - ELETROBRÁS e de suas subsidiárias e dá outras providências. 1998.

BRASIL. Lei 12.783 de 2013. Dispõe sobre as concessões de geração, transmissão e distribuição de energia elétrica, sobre a redução dos encargos setoriais e sobre a modicidade tarifária; altera as Leis $\mathrm{n}^{\circ} \mathrm{s} 10.438$, de 26 de abril de 2002, 12.111, de 9 de dezembro de 2009, 9.648, de 27 de maio de 1998, 9.427, de 26 de dezembro de 1996, e 10.848, de 15 de março de 2004; revoga dispositivo da Lei $n^{\circ} 8.631$, de 4 de março de 1993; e dá outras providências. 2013

BRASIL. Lei 13.848 de 2019. Dispõe sobre a gestão, a organização, o processo decisório e o controle social das agências reguladoras, altera a Lei $\mathrm{n}^{\circ}$ 9.427, de 26 de dezembro de 1996, a Lei ${ }^{\circ}$ 9.472, de 16 de julho de 1997, a Lei ${ }^{\circ}$ 9.478, de 6 de agosto de 1997, a Lei ${ }^{\circ}$ 9.782, de 26 de janeiro de 1999, a Lei $n^{\circ}$ 9.961, de 28 de janeiro de 2000, a Lei $n^{\circ}$ 9.984, de 17 de julho 
de 2000, a Lei $\mathrm{n}^{\circ}$ 9.986, de 18 de julho de 2000, a Lei $\mathrm{n}^{\circ} 10.233$, de 5 de junho de 2001, a Medida Provisória $n^{\circ} 2.228-1$, de 6 de setembro de 2001, a Lei ${ }^{\circ} 11.182$, de 27 de setembro de 2005, e a Lei $\mathrm{n}^{\circ}$ 10.180, de 6 de fevereiro de 2001.2019.

BRASIL. Lei 13.874 de 2019. Institui a Declaração de Direitos de Liberdade Econômica; estabelece garantias de livre mercado; altera as Leis nos 10.406, de 10 de janeiro de 2002 (Código Civil), 6.404, de 15 de dezembro de 1976, 11.598, de 3 de dezembro de 2007, 12.682, de 9 de julho de 2012, 6.015, de 31 de dezembro de 1973, 10.522, de 19 de julho de 2002, 8.934, de 18 de novembro 1994, o Decreto-Lei $\mathrm{n}^{\circ}$ 9.760, de 5 de setembro de 1946 e a Consolidação das Leis do Trabalho, aprovada pelo Decreto-Lei no 5.452 , de $1^{\circ}$ de maio de 1943; revoga a Lei Delegada ${ }^{\circ} 4$, de 26 de setembro de 1962, a Lei ${ }^{\circ} 11.887$, de 24 de dezembro de 2008, e dispositivos do Decreto-Lei $\mathrm{n}^{\mathbf{0}}$ 73, de 21 de novembro de 1966; e dá outras providências.2019.

CASA CIVIL et al. Diretrizes Gerais e Guia Orientativo para Elaboração de Análise de Impacto Regulatório AIR / Subchefia de Análise e Acompanhamento de Políticas Governamentais Brasília: Presidência da República, 2018. Disponível em https://www.gov.br/casacivil/ptbr/centrais-de-conteudo/downloads/diretrizes-gerais-e-guia-orientativo_final_27-09-

2018.pdf/view. Acesso em 20 de ago. de 2019.

CASA CIVIL. Histórico do PRO_REG. Disponível em https://www.gov.br/casacivil/ptbr/assuntos/governanca/regulacao/sistema-regulatorio-brasileiro/historico-do-pro-reg. Acesso em 07 de abril de 2019.

DEPARTAMENTO NACIONAL DE ÁGUAS E ENERGIA. Portaria 244 de 1996. Define as instalações de transmissão que passam a compor as redes básicas dos sistemas elétricos interligados Sul / Sudeste / Centro - Oeste e Norte / Nordeste. 1996.

DINIZ. Maria Helena. Dicionário Jurídico. 3ª edição. São Paulo. Saraiva.2012.

ESTADOS UNIDOS. Decreto Presidencial 12.291 de 1981. The provisions of Executive Order 12291 of Feb. 17, 1981, appear at 46 FR 13193, 3 CFR, 1981 Comp., p. 127, unless otherwise noted. 1981.

ESTADOS UNIDOS. Decreto Presidencial 12.866 de 1993. Regulatory Planning and Review. 1993.

ESTADOS UNIDOS. Decreto Presidencial 13.563 de 2011. Improving Regulation and Regulatory Review. 2011.

LIMA, Valéria Athayde Fontelles de. A avaliação de impacto regulatório no contexto brasileiro. Rio de Janeiro, 2010. 158 f Dissertação de Mestrado. Instituto de Economia, Universidade Federal do Rio de Janeiro, 2010.

MARQUES Fábio Silva e SOARES Caio Cesar Esteves. Definição legal da composição das instalações de transmissão e adequação do critério aplicado pela ANEEL: por uma revisão baseada em legalidade e funcionalidade in $\mathbf{A}$ interface do direito de energia. Coordenação Urias Martiniano Garcia Neto. - 1. ed. - Rio de Janeiro. Synergia, 2020. No prelo.

MINISTÉRIO DE MINAS E ENERGIA. Portaria 120 de 2016. 2016. 
OECD. Regulatory Impact Analysis. Best Practices in OECD Countries.1997. Disponível em https://www.oecd.org/regreform/regulatory-policy/35258828.pdf. Acesso em 14 de jan. de 2018.

OECD. Review of Regulatory Governance in South East Europe. 2003.

OECD. Introdutory Handbook for undertaking Regulatory Impact Analysis (RIA), OECD, Publish, 2008. Disponível em https://www.oecd.org/gov/regulatorypolicy/44789472.pdf. Acesso em 20 de dezembro de 2018.

OCDE. Improving de quality of regulations. OCDE Policy Brief. 2009.

OECD. Recomendação do Conselho sobre Política Regulatória e Governança, Organização para a Cooperação e Desenvolvimento Econômico, 2012. Disponível em https://www.oecd.org/gov/regulatory-policy/Recommendation\%20PR\%20with\%20cover.pdf. Acesso em 05 de fev. de 2018.

OCDE. Measuring regulatory performance: evaluating regulatory management tools and programs. Paris: OCDE Publish, 2012b.

OECD. Better Regulation Practices across the European Union. 2019. Disponível em https://www.oecd.org/gov/regulatory-policy/better-regulation-practices-across-the-europeanunion-9789264311732-en.htm. Acesso em 14 de out.2020.

PESSOA VALENTE, Patricia Rodrigues. Avaliação de Impacto Regulatório: uma ferramenta a disposição do Estado. 2010. 218 f. Dissertação de Mestrado. Faculdade de Direito, Universidade de São Paulo, São Paulo. 2010.

UNIÃO EUROPEIA. Libro Branco sobre Governança. 2001. Disponível em: https://eurlex.europa.eu/legal-content/PT/TXT/HTML/?uri=LEGISSUM:110109\&from=PT. Acesso em 15 de maio de 2019.

UNIÃO EUROPEIA. Países integrantes da União Europeia. Disponível em https://europa.eu/european-union/about-eu/countries_pt. A. Acesso em 02 de set. de 2020.

MELO, Cristina Andrade. Audiência Pública na Função Administrativa. Editora Arraes, 2016.

OLIVEIRA, Rafael Carvalho Rezende. Novo Perfil da Regulação Estatal: Administração Pública de resultados e análise de impacto regulatório. Forense. 2015.

SALGADO Lucia Helena; BORGES, Eduardo Bizzo de Pinho. Análise de Impacto Regulatório: Uma Abordagem Exploratória. Texto para Discussão. Instituto de Pesquisa Econômica Aplicada - IPEA, 2010.

SILVA, Aline Veronese et al. Performance benchmarking models for electricity transmission regulation: Caveats concerning the Brazilian case. Utilities Policy. Elsiever. 60. 2019

UGEDA SANCHES, Luiz Antonio. Curso de Direito de Energia: Tomo I: Da História. Instituto de Geodireito. São Paulo. 2011 
PECI. Alketa. Avaliação do impacto regulatório e sua difusão no contexto brasileiro. Revista de Administração de Empresas. Vol 51, nº 04, jul-ago 2011. Fundação Getúlio Vargas. Disponível em https://www.fgv.br/rae/artigos/revista-rae-vol-51-num-4-ano-2011-nid46703/Alketa Peci. Acesso em 12 de março de 2019.

PROCURADORIA GERAL ESPECIALIZADA. Parecer 183/2014-PGE/ANEEL/PGF/AGU. 2014.

PROCURADORIA GERAL ESPECIALIZADA. Parecer 00786/2015/PFANEEL/PGF/AGU. 2015.

TARELHO, Thais Araujo Rato; BERMANN CÉLIO. Democracia participativa na Agência Nacional de Energia Elétrica: uma análise da sua efetividade nas audiências/consultas públicas in A interface do direito de energia. Coordenação Urias Martiniano Garcia Neto. - 1. ed. - Rio de Janeiro. Synergia, 2020. No prelo. 
ANEXO I

'FORMULÁRIO DE ANÁLISE DE IMPACTO REGULATÓRIO

\begin{tabular}{|l|l|}
\hline Data: 2/6/2015 & Área Responsável: SRD \\
\hline Título da Regulação: & \\
Transferência de Demais Instalaçōes de Transmissão - DIT para as distribuidoras. \\
\hline
\end{tabular}

Qual é o problema que se quer resolver? Qual é o público-alvo?

Descrever a natureza e a extensăo do problema.

A REN $n^{0} 67 / 2004$ deu tratamento especifico às instalaçōes de tensão inferior a $230 \mathrm{kV}$ de propriedade de transmissora, classificando-as como DIT. Já as regras de acesso nessas instalações foram estabelecidas na REN no 68/2004. Essa Resoluçăo transferiu para as transmissoras a responsabilidade pelos reforços nas DIT.

O modelo estabelecido pelas REN acima citadas passou a apresentar, posteriormente, alguns inconvenientes. Em especial, destaca-se a dificuldade de garantir as ampliações e reforços das DIT no ritmo demandado pelos usuários do sistema de distribuição, notadamente nos niveis de tensão mais baixos.

Os consumidores também sentem efeitos da existência das DIT, que, por serem instalaçōes de transmissão, tẻm regras diferenciadas de conexão, definidas no Módulo 3 dos Procedimentos de Rede e, normalmente, padrōes superiores aos empregados na distribuiçăo. Desse modo, apesar de também estarem no ámbito da distribuiçăo, os agentes que se conectam em DIT recebem tratamento diferente ao que é dado aos seus semelhantes simplesmente por estarem em instalaçōes de propriedade de uma transmissora, sem motivação técnica aparente.

Identficar os principais grupos afetados pelo problema.

Distribuidoras, transmissoras de energia elétrica e usuários finais.

Estabelecer as causas do problema.

Por serem classificadas como instalações de transmissão, o planejamento da expansão das DIT é centralizado, definido no PAR-DIT elaborado anualmente pelo ONS em consonăncia com o planejamento de responsabilidade da Empresa de Pesquisa Energética - EPE e do Ministério de Minas e Energia MME. Todavia, essas instalaçōes desempenham função de distribuição, o que exige um maior dinamismo e celeridade de sua expansăo para acompanhar o crescimento da demanda em niveis de tensão mais baixos.

O planejamento setorial centralizado não determina novas obras de expansão de DIT, restringindose a reforços, 0 que tem resultado em conflitos no tocante as responsabilidades das distribuidoras para execução de obras de expansăo. Dada a impossibilidade de autorizar a expansão das DIT, outras soluçōes acabam sendo viabilizadas para assegurar o atendimento ao crescimento do mercado de energia elétrica. Como alternativa, săo autorizadas ou licitadas expansōes no sistema de transmissăo ou reforços

"A Nota Técnica é um documento emilfodo pelas Unidades Organizacionais e destina-se a subsidiar as decisōes da Agạncia. 
em DIT. A consequência é que se adotam soluçōes năo ideais de planejamento, que normalmente são mais demoradas e onerosas ao consumidor final.

A existência das DIT faz com que entre o sistema de transmissão e o usuário final haja trechos de rede sobre os quais a distribuidora não pode executar plenamente suas atividades. Para cumprir as obrigações impostas pelo contrato de concessão, a distribuidora se vê dependente de entes que fazem o planejamento centralizado e das transmissoras executarem obras em åmbito de distribuiçăo. Logo, uma parcela da atividade de distribuição é executada por outros, embora a responsabilidade recaia exclusivamente sobre a distribuidora. A execução de uma mesma atividade (distribuição) por mais de um agente acaba por dificultar a atribuição de responsabilidades e promover uma ineficiência operacional. Logo, a liberdade para planejar e operar os ativos, que a distribuidora precisa usufruir para cumprir as obrigaçães impostas pelo Contrato de Concessão, fica reduzida em função da existência de ativos de distribuição operados e planejados por outrem.

0 resultado disso é prejuizo à adequada prestação dos serviços aos usuários finais. Para realizar o atendimento a nova carga, por exemplo, a distribuidora depende da emissão de autorização especifica para que a transmissora realize reforço na DIT acessada.

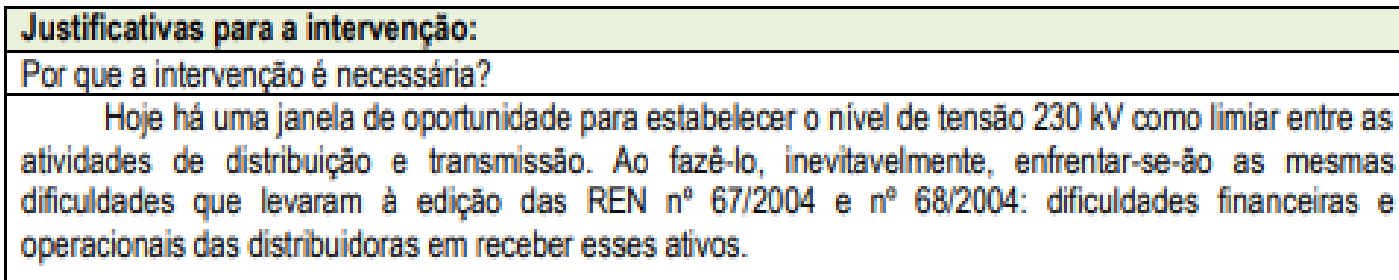

Atualmente, as dificuldades financeiras estão relacionadas, principalmente, ao ressarcimento dos investimentos năo amortizados das transmissoras. No entanto, boa parte dessa questão foi sanada com a edição da Lei $n^{0}$ 12.783/2013, conversão da Medida Provisória - MP nº 579/2012. Essa Lei promoveu a indenizaçăo dos ativos de transmissăo não amortizados como condiçăo para renovaçăo antecipada dos contratos, dentre os quais, encontravam-se as DIT. Desse modo, a Lei amortizou as DIT existentes quando da sua publicação, e, portanto, o óbice financeiro encontra-se reduzido.

Do lado operacional, acredita-se que os empecilhos existentes na época das privatizaçōes tenham sido superados. Naquele momento de reestruturaçăo, as distribuidoras passavam por muitas mudanças, 0 que dificultava concentrar esforços em promover ampliaçōes nas DIT. Ainda que os desafios atuais das distribuidoras sejam amplos, as empresas já se encontram estabelecidas há quase duas décadas. Além disso, os inconvenientes surgidos após as REN $n^{\circ} 67 / 2004$ e $n^{\circ} 68 / 2004$ são maiores do que as eventuais dificuldades operacionais que as distribuidoras teriam para passarem a operar as DIT.

Em outras palavras, do ponto de vista operacional, o principal motivador para a criaçăo das DIT já năo existe mais, de modo que é mais adequado conviver temporariamente com os ônus de transferência das DIT do que conservar essas instalaçōes sob responsabilidade das transmissoras e manter as dificuldades anteriormente citadas.

Assim, pretende-se aproveitar esse momento especifico em que as DIT encontram-se, em sua maioria, amortizadas pelos efeitos da Lei $n^{0} 12.783 / 2013$ para promover a transferência dessas 
instalaçōes para as distribuidoras.

Existem outras formas de intervençăo que não a implementaçăo de nova regulamentaçăo?

Não. A alternativa à não ediçăo de um novo regulamento é continuar convivendo com os inconvenientes acima relatados.

Objetivos perseguidos:

Quais săo os objetivos e os efeitos esperados com a regulamentação?

O objetivo da regulamentação é atribuir à distribuidora a responsabilidade por planejar, operar e manter todas as instalaçōes que compõem o sistema de distribuiçăo, para que ela fique inteiramente responsável pelos ativos que interligam o sistema de transmissão ao usuário final.

0 efeito esperado é que o ritmo de melhoria e expansão das instalaçōes hoje classificadas como DIT tenham o dinamismo exigido pelo sistema de distribuição, notadamente nos niveis de tensão mais baixos. Adicionalmente, espera-se a adoção de soluçōes ideais de planejamento e isonomia no acesso dos usuários finais.

Qual é o prazo para a implantação do regulamento?

Inicialmente, propōe-se que as DIT em operação sejam transferidas ao longo de très anos.

\section{Opçöes consideradas:}

Quais as alternativas para solução do problema foram consideradas? atual.

Além da opção de promover a transferência das DIT, considerou-se a opção de manter a situação

Justificar a opçăo escolhida, inclusive a de não regular.

A manutenção da situaçăo atual implicaria em manter os problemas dela decorrentes, citados nos itens anteriores. Os inconvenientes acima relatados são maiores do que as dificuldades momentåneas que as transmissoras e distribuidoras enfrentarão ao longo do processo de transferência.

Análise de custo-beneficio:

Descrever e mensurar os custos e os beneficios, em termos financeiros, da regulaçăo para os principais grupos afetados.

Os principais custos e beneficios financeiros decorrentes da regulamentação para os principais grupos afetados são:

Distribuidoras:

- Obrigação de operar e manter as DIT transferidas;

- Aumento dos custos de transporte, para algumas distribuidoras;

- Pagamento da parcela năo amortizada das DIT;

- Adaptaçăo das instalações recebidas aos padrōes técnicos da distribuidora.

Transmissoras: 
- Redução da RAP associada às DIT transferidas;

- Diminuição significativa da responsabilidade por operar e manter os ativos em tensão inferior a $230 \mathrm{kV}$;

- Perda de contratos de compartilhamento de infra-estrutura;

- Direcionamento de mão-de-obra para realizaçăo das transferências.

Elencar custos e beneficios năo financeiros. Avaliar os riscos envolvidos nas alternativas consideradas.

Há possibilidade de o pagamento das indenizaçōes afetar o nivel de investimentos em melhoria e expansāo das distribuidoras. Todavia, simulaçōes indicam que o valor a ser indenizado é pouco significativo quando comparado com os valores historicamente investidos pelas distribuidoras.

As distribuidoras terão maior liberdade para planejar e operar a parcela do sistema de distribuição que hoje se encontra sob responsabilidade das transmissoras.

Para as transmissoras, a transferência das DIT representa uma oportunidade para concentrar esforços nos niveis de tensão superiores a 138 kV.

Algumas transmissoras terão redução significativa de sua receita após a transferência das DIT, o que poderia reduzir a capacidade de investimento em novos empreendimentos. No entanto, isso ocorreria de forma individualizada, sem potencial para afetar a capacidade de investimento de todo o setor de transmissão.

Para os usuários finais, seria assegurado isonomia de tratamento quando do acesso a um mesmo nivel de tensăo.

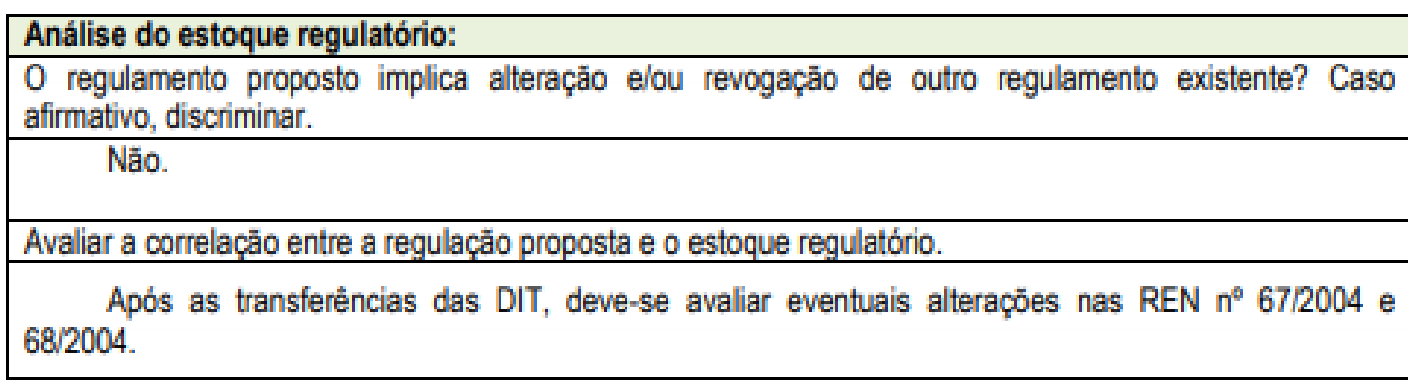

Acompanhamento dos efeitos do regulamento proposto:

Propor alternativas para acompanhamento dos efeitos do regulamento proposto.

As áreas técnicas e de fiscalização da Agência acompanharão as dificuldades relacionadas ao processo de transferência. 


\section{ANEXO II \\ Questionário - Demais Instalações de Transmissão - DIT}

Em 2015 a Agência Nacional de Energia Elétrica ("ANEEL") determinou a abertura da Audiência Pública ${ }^{\circ}$

41, com vistas a "obter subsídios para a análise da proposta de transferência das Demais Instalações de Transmissão - DIT para as distribuidoras"

Em 2016 foi determinada a abertura da $2^{\circ}$ fase da mesma Audiência Pública.

Em 2017 foi publicada a Resolução Normativa ANEEL n 758 a qual "estabelece as condições gerais

para a incorporação das Demais Instalações de Transmissão - DIT listadas no Anexo ao Ativo

Imobilizado pelas concessionárias do serviço público de distribuição de energia elétrica."

Para acesso completo aos documentos disponibilizados na Audiência Pública n 41/2015 por favor consulte:

https://www.aneel.gov.br/audiencias-publicas-antigas?

p_auth=ntdTLHr0\&_p_p_id=participacaopublica_WAR_participacaopublicaportlet\&p_p_lifecyc

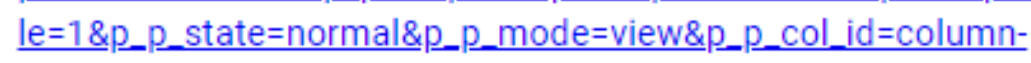

2\&_p_p_col_pos=1\&p_p_col_count=2\&_participacaopublica_WAR_participacaopublicaportlet_ $\underline{\text { ideParticipacaoPublica=985\&_participacaopublica_WAR_participacaopublicaportlet_javax.p }} \underline{\underline{p}}$ ortlet. action=visualizarParticipacaoPublica

A pesquisa tem cunho acadêmico e a identidade dos entrevistados não será revelada.

Escolha apenas uma alternativa em cada uma das questões 


\section{Questionário - Demais Instalações de Transmissão - DIT}

9 responses

Qual o seu cargo na empresa em que trabalha?

9 responses

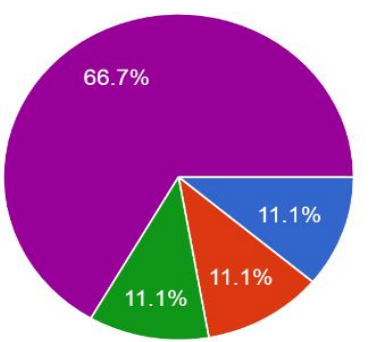

Analista regulatório

- Advogado

Engenheiro

Coordenador

- Gerente

Diretor

A empresa em que você trabalha se enquadra como transmissora ou distribuidora de energia elétrica

9 responses

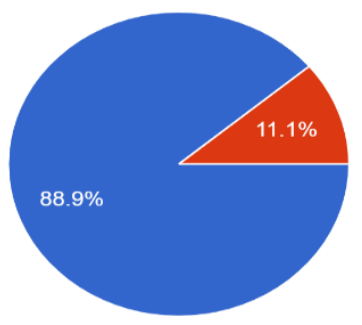

Transmissora

Distribuidora

Você sabe o que são Demais Instalações de Transmissão - DIT?

9 responses

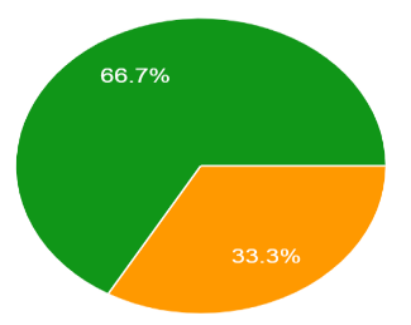

Não

Pouco

Razoavelmente

Muito 
Você se lembra da Audiência Pública n 41/2015 promovida pela Agência Nacional de Energia Elétrica ("ANEEL") que tratou da transferência das Demais Instalações de Transmissão - DIT? 9 responses
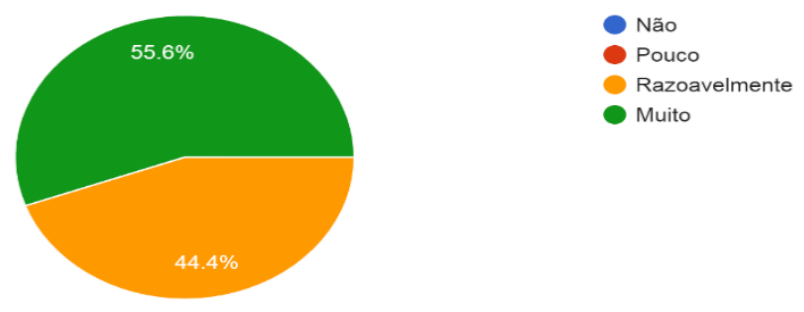

Na sua opinião, a Audiência Pública n 41/2015 oportunizou a ampla manifestação dos agentes? 9 responses
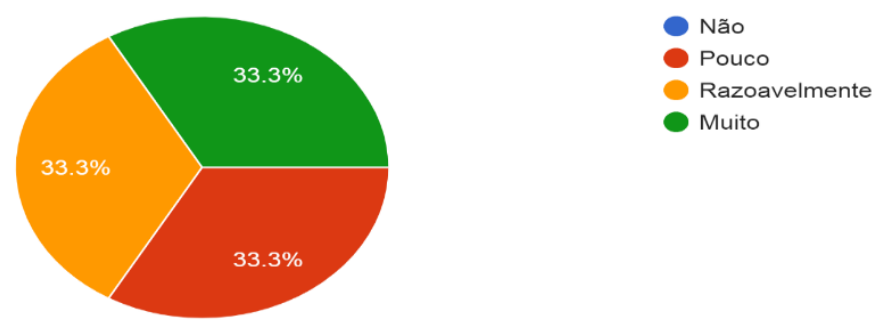

Muito

Na sua opinião, na condução da Audiência Pública n 41/2015, a ANEEL se mostrou aberta a acatar opiniões e soluções diversas daquelas já postas no âmbito da Audiência Pública?

9 responses

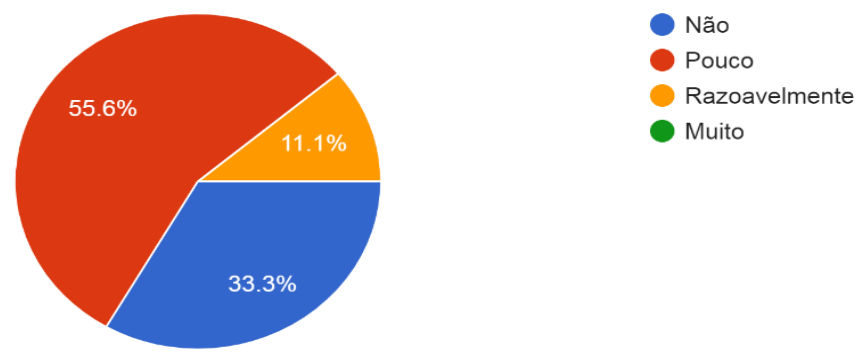

Você conhece o resultado final da Audiência Pública n 41/2015?

9 responses

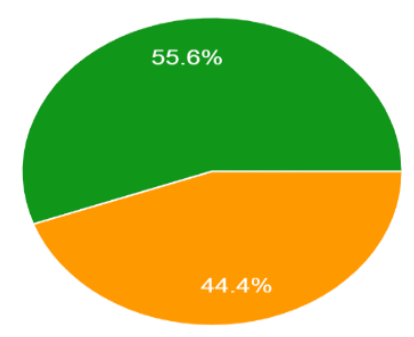
Não
- Pouco
Razoavelmente
- Muito


Você considera que a decisão de transferência das Demais Instalações de Transmissão - DIT considerou a melhor alternativa técnica, regulatória e financeira?

9 responses

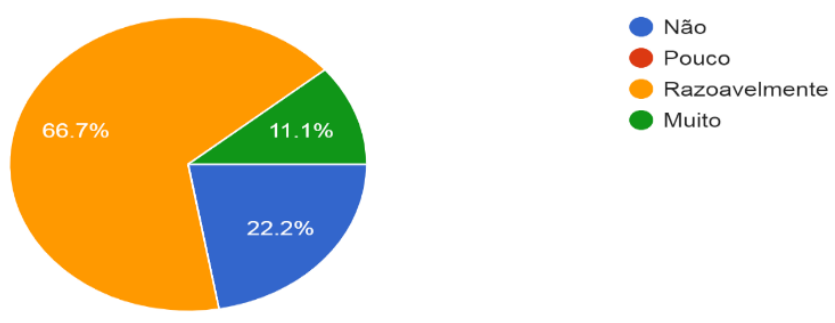

A empresa em que você trabalha foi afetada pela proposta de Transferência das Demais Instalações de Transmissão - DIT incluida na Audiência Pública n 41/2015 promovida ANEEL 9 responses

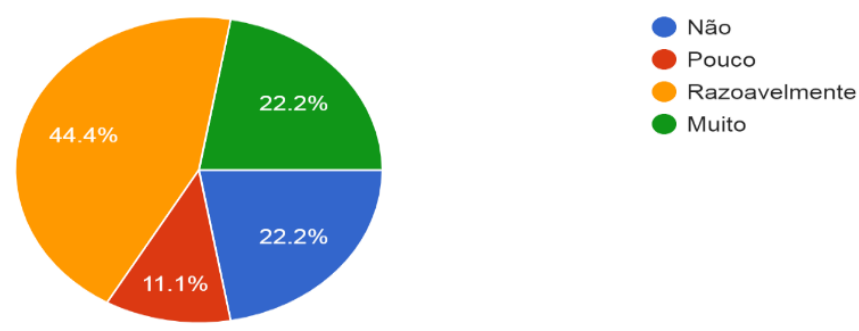

Você conhece a Análise de Impacto Regulatório 9 responses

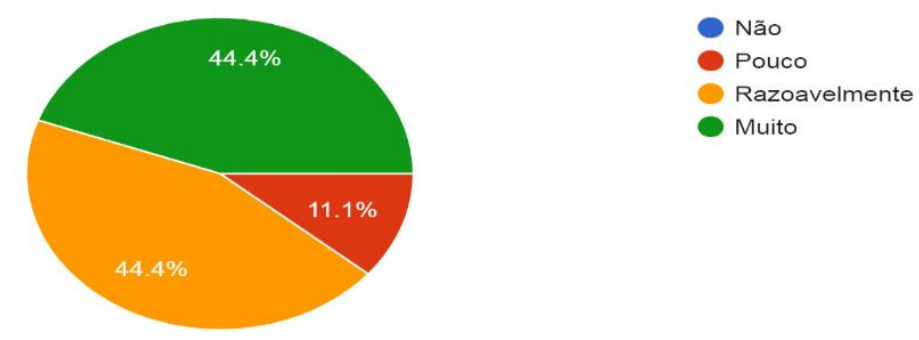

Na sua opinião, caso tivesse sido feita a Análise de Impacto Regulatório para o caso das Demais Instalações de Transmissão - DIT, a sua transferência teria sido proposta?

9 responses

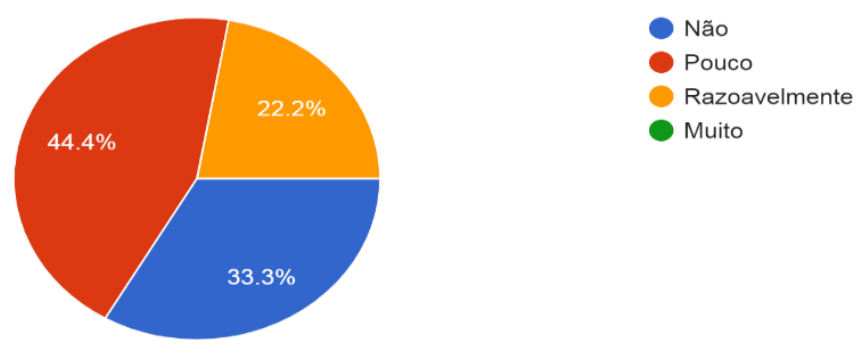

Você tem algum comentário adicional sobre a relação entre a Análise de Impacto Regulatório e a decisão de transferência das Demais Instalações de Transmissão? 
Se realizada de acordo com a regulamentação, a Análise de Impacto Regulatório confrontaria questões básicas da legislação a respeito do tema das DIT. Uma dessas questões diz respeito ao critério utilizado para a classificação das instalações de transmissão de rede básica e as demais instalações de transmissão. A ANEEL, inicialmente, nessa classificação, utilizou tão somente o critério da tensão das instalações e a função desempenhada por estas. No entanto, numa análise mais detalhada do disposto no Art. 17 da Lei 9.074/95: “Art. 17. O poder concedente deverá definir, dentre as instalações de transmissão, as que se destinam à formação da rede básica dos sistemas interligados, as de âmbito próprio do concessionário de distribuição, as de interesse exclusivo das centrais de geração e as destinadas a interligações internacionais. É possível verificar que ao se referir a instalações "que se destinam" o legislador estava se referindo à função desempenhada pela instalação como critério para se definir a sua classificação e não a sua tensão. Assim, a simples definição de critério de classificação baseado única e exclusivamente no nível de tensão não atende o conceito definido na Lei n. ${ }^{\circ}$ 9.074/1995, que faz referência à destinação de tais instalações para fins de classificação. Do mesmo modo, ao se referir a instalações "de âmbito próprio do concessionário de distribuição", a lei está confirmando a referência à função. Nessa linha, entendo que a AIR seria o meio propício para se confrontar essas questões com vistas à uma condução mais adequada do tema, de forma otimizada e com maior eficiência.

Ao tratar de forma genérica não se oportunizou melhores soluções técnicas e financeiras.

A Análise de Impacto Regulatório deve ser feita de forma prévia a abertura de Consulta Pública e de maneira abrangente, contemplando todas as possíveis alternativas da nova regulamentação e seus respectivos impactos, de forma que a proposta final não fique restrita a visão do regulador ou a paradigmas previamente estabelecidos.

Acredito que sempre uma maior discussão e um planejamento prévia, como o caso do AIR, acarreta em melhores resultados. Entretanto, existem interesses distintos das partes que por vezes impede a melhor orientação para os casos, gerado por vezes pela assimetria de informações entre os agentes.

Penso que a análise de impacto regulatório deve apresentar a estimativa de redução na tarifa ao consumidor final, e melhoria nos indicadores de qualidade (DEC e FEC) em relação a situação existente. $\mathrm{Na}$ AP 41/2015 houve manifestações que a transferência traria estes benefícios, mas sem apresentar sequer uma metodologia pra estimar a economia e a redução dos indicadores. Mas a verdade é que a Transmissora gostaria de apresentar esta conta pra provar que o custo pra sociedade aumentará, e a Distribuidora o contrário. Como o cálculo depende de informações dos dois, obviamente um não fornecerá informação pro outro de forma espontânea.

A intenção do regulador, cujo processo foi conduzido internamente na ANEEL, basicamente pela SRD, era de transferir essas instalações, independentemente do interesse das partes, distribuidoras e transmissoras. Todas as dificuldades de cunho técnico/operacional foram levantados e ainda assim a decisão culminou com a transferência compulsória das DIT, atendendo a interesses de uma minoria de distribuidoras que se beneficiaria com esta escolha. Então não considero que a AIR modificaria este cenário.

Não

Não

Tema relevante e que deve ser utilizado pelos entes reguladores 